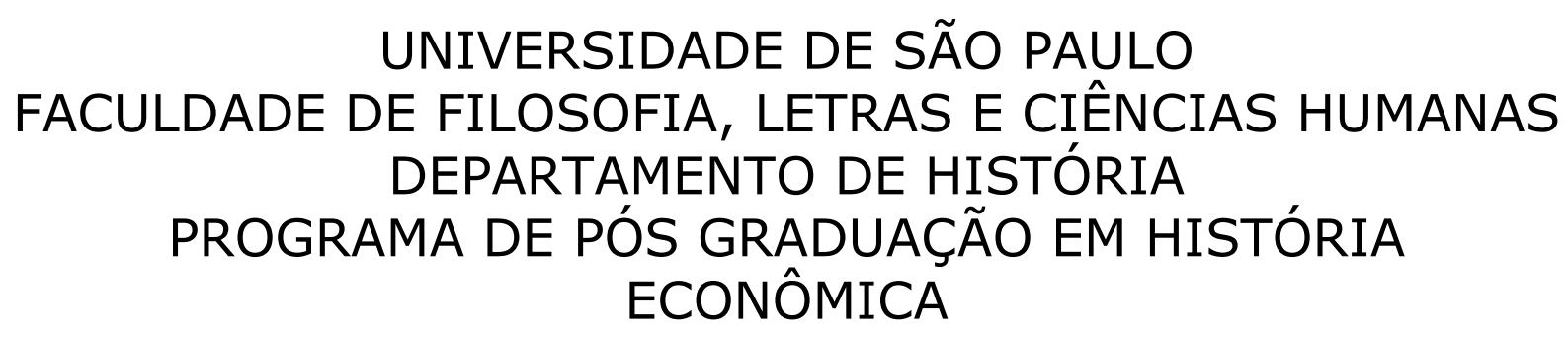

DANIEL DO VAL COSENTINO

\title{
Formação do Pensamento Econômico Brasileiro no século XIX
}

São Paulo

2016 


\section{UNIVERSIDADE DE SÃO PAULO \\ FACULDADE DE FILOSOFIA, LETRAS E CIÊNCIAS HUMANAS DEPARTAMENTO DE HISTÓRIA PROGRAMA DE PÓS GRADUAÇÃO EM HISTÓRIA ECONÔMICA}

\section{Formação do Pensamento Econômico Brasileiro no século XIX}

Tese apresentada ao programa de Pós Graduação em História Econômica da Faculdade de Filosofia, Letras e Ciências Humanas da Universidade de São Paulo, para a obtenção do título de Doutor em Ciências, Área de Concentração História Econômica. 
Daniel do Val Cosentino

Formação do Pensamento Econômico Brasileiro no século XIX

Tese apresentada ao programa de Pós Graduação em História Econômica da Faculdade de Filosofia, Letras e Ciências Humanas da Universidade de São Paulo, para a obtenção do título de Doutor em Ciências, Área de Concentração História Econômica.

São Paulo, de de 2016. 
Para Ana Camila, meu amor, minha companheira, meu porto seguro Para Bia e Luli, meus pequenos amores, razões do meu viver Para minha mãe, com muita saudade da sua lucidez e ternura 


\section{Agradecimentos}

Esta tese é o resultado de anos de reflexão e de muita luta. Não foi fácil chegar até aqui, muita coisa aconteceu desde que iniciei a minha primeira aventura no Programa de Doutorado. Nesta jornada já dei aula em algumas Universidades, passei em 2 concursos públicos, trabalhei em cidades diferentes da minha querida Belo Horizonte, me casei, tive a enorme alegria de ser pai e ter duas filhas maravilhosas, vi e sofri muito ao perceber a minha mãe perder lentamente a lucidez, tive a indescritível sensação de ver o meu Galo querido campeão da Libertadores e da Copa do Brasil, conheci muitas pessoas interessantes, fiz novos amigos e conheci lugares maravilhosos. Hoje sou uma pessoa completamente diferente do que eu era antes do início desta caminhada. Tanto se passou e eu obviamente não cheguei aqui sozinho. Por isso preciso agradecer eternamente a todos aqueles que me ajudaram direta ou indiretamente a chegar até aqui.

Ao Professor José Jobson de Andrade Arruma, meu orientador, por ter me recebido em um momento tão delicado, confiado em mim e dado suporte institucional único e liberdade plena para executar o meu trabalho. Agradeço enormemente sua paciência, dedicação e orientação precisa nos momentos mais decisivos e necessários.

Aos Professores Nelson Nozoe e Renato Colistete pela paciência e pelos ensinamentos e formação em suas respectivas disciplinas.

À Professora Vera Ferlini pelo auxílio e suporte quando precisei.

Aos funcionários da USP, sobretudo ao Nelson Caetano, secretário da Pós Graduação, por todo suporte e gentileza.

Ao Professor João Antonio de Paula, por um dia ter me recebido e aberto as portas do mundo acadêmico, pela disponibilidade, pelo diálogo, pelos ensinamentos e pela generosidade.

Ao Professor Frederico Gonzaga, pela amizade leal e sincera e por todo suporte quando fui Professor Substituto na FACE/UFMG. 
Ao Professor Alexandre Mendes Cunha, pela amizade e por ter sido tão importante quando eu ainda era aluno de graduação.

À FACE/UFMG, pela primeira oportunidade como professor e por ter me dado o prazer de ter dado aula no antigo e saudoso prédio da Rua Curitiba.

Ao Centro Universitário UNA, espaço fundamental da minha formação docente.

À Universidade Federal de Alfenas, Campus Varginha, pela oportunidade única e inesquecível de ter participado de sua construção e pelo apoio institucional indispensável.

À Universidade Federal de Ouro Preto, pelo abrigo nos últimos anos que me permitiu reduzir a distância entre o trabalho e aqueles que tanto amo. Sobretudo ao DECEG, pelo apoio e liberação das atividades nos momentos em que precisei e à PROPP, pelo auxílio financeiro dos últimos meses.

Aos amigos queridos.

Ao Professor Thiago Gambi, amigo leal e companheiro de tantas jornadas, agradeço por todo o diálogo e troca de experiências, por ter participado da Banca de Qualificação e dado sugestões tão valiosas e por ser, sobretudo, tão amigo dos amigos como é.

Ao Professor Alexandre Saes, grande amigo e camarada, por toda ajuda e incentivo, pela companhia e pelo trabalho quando chegamos em Varginha, pelo suporte e auxílio em apresentar o Professor Jobson quando mais precisei e pelas excelentes sugestões na Banca de Qualificação.

Aos Professores Michel Marson, Pamila Sivieiro, Deive Oliveira, Angelo Prates, Paulo Roberto Souza, Roberto Pereira Silva e Marcel Pereira da Silva, amigos tão queridos que deixei em Varginha, na UNIFAL-MG, dos quais tenho muita saudade, pelos quais tenho enorme carinho.

Aos Professores Francisco Horácio, Leonardo de Deus, André Mourthé e José Artur dos Santos Ferreira, amigos queridos e companheiros de tantas batalhas na UFOP. Ao Felipe, secretário e guerreiro incansável do DECEG/UFOP. 
Aos meus alunos, que me desafiam e me inspiram a ser cada dia melhor. Em especial aos ex-orientandos Francisco Monticeli, Rafaela Carvalho, Camila Amaral e Janaína Battahin, que me deram enorme alegria ao entrar no mestrado.

Ao casal Marcelo e Jordana, pelo carinho e pela revisão competente e rápida.

Ao Galo, que me deu a indescritível alegria de ser campeão da Libertadores em 2013.

Aos meus tios e tias, em especial Tia Lili e Tio Davi, tão presentes e carinhosos, e a Tia Lúcia, tia que tive a sorte de ganhar e que nos ajuda tanto.

Aos meus primos e primas, em especial Peu e Lu, pelo carinho fraterno e por todo amor com que tratam as meninas.

Aos meus avós, aqueles que aqui estão Chico e Conceição, e daqueles que tenho enorme saudade, Paulo, Olympia, Carminha, Camila e Ana Marta (avós que a vida me deu de presente).

À minha querida sogra, Alzira, pela paciência em aturar as nossas manias e chatices, pelo carinho, pelo queijo que trás de Uberaba, pelo pão de queijo delicioso que faz, pela ajuda e amor incondicional com as meninas.

À minha irmã Ana e seu querido companheiro João, pela convivência, pelo carinho e pelo amor fraterno.

À minha mãe Antonieta, que infelizmente não poderá acompanhar e celebrar este momento lúcida, mas que estaria muito feliz e orgulhosa, pelo exemplo de filha, de liderança, de coragem e de luta. Mãe, tenho muita saudades de sua lucidez, do seu carinho, do seu colo e de seu tempero.

Ao meu pai, Chico, exemplo de dignidade, dedicação e perseverança. Modelo de pai, professor e intelectual; exemplo de conduta ética, profissional e de vida. E que nos últimos anos se redobrou para ser pai e mãe, mesmo sofrendo tanto com perda de lucidez da minha mãe. 
Agradeço por todo suporte e por tudo que fez e faz para que sejamos felizes.

Às minhas filhas amadas e queridas. À Beatriz e a Luísa por seus sorrisos inocentes e sinceros, pelos abraços e beijos babados, por me fazer sentir único e completo, por encher os meus dias de alegria e amor incondicional. Às duas peço desculpas pela ausência e impaciência dos últimos tempos, vocês foram a melhor coisa que poderia ter acontecido para eu e sua mãe.

À Ana Camila, minha querida e amada esposa, por todo companheirismo e paciência em me aguentar, por ter me dado duas filhas maravilhosas e por todo amor, cuidado e carinho que tem por elas, por me completar e me fazer feliz. Peço desculpas pela loucura dos últimos tempos, por te fazer sentir culpada sem ter culpa, eu não chegaria na esquina, nem suportaria viver um segundo sem você. 


\section{RESUMO}

COSENTINO, Daniel do Val. Formação do Pensamento Econômico Brasileiro no século XIX. Tese (Doutorado). Universidade de São Paulo, Faculdade de Filosofia, Letras e Ciências Humanas, São Paulo, 2016.

Este trabalho analisa a formação do Pensamento Econômico Brasileiro no século XIX. Um de seus objetivos é argumentar a favor da possibilidade da existência de pensamentos econômicos nacionais em detrimento da visão que entende a teoria econômica como universal. Além disso, sustentamos a ideia de que é possível, no caso do Brasil, abordar a questão a partir do século XIX, ao contrário de grande parte dos estudos sobre Pensamento Econômico Brasileiro, que concentram suas abordagens no século XX e na problemática da superação do subdesenvolvimento.

Assim, discutimos a formação das ideias, do Brasil e suas interpretações, relacionando-as ao Pensamento Econômico Brasileiro e suas possibilidades de abordagem.

Procuramos discutir teórica e metodologicamente a questão da universalidade e da nacionalidade na teoria econômica, negando a primeira e afirmando a segunda, propondo que faz sentido, além de ser fundamental, considerar a teoria econômica e seu pensamento a partir das especificidades de cada nação. Disso deriva o Pensamento Econômico Brasileiro, resultado de análises e, muitas vezes, de adaptações e da difusão de teorias produzidas em outros contextos, a partir de nossas particularidades e condição periférica, o que the confere originalidade e importância.

A partir disso, argumentamos que ser factível abordar o tema tendo como referência o século XIX. O que nos leva a organizar, articular e sistematizar o que chamamos de Pensamento Econômico Brasileiro no século XIX, tendo como referências as análises e discussões do pensamento de José da Silva Lisboa, o Visconde de Cairu, o Ensino de Economia Política no Brasil durante o século XIX e o debate monetário entre papelistas e metalistas, enfatizando as ideias de Rodrigues Torres, Souza Franco e Mauá.

Palavras-chave: Pensamento Econômico Brasileiro; século XIX; nacionalidade; originalidade; difusão; adaptação. 


\section{ABSTRACT}

COSENTINO, Daniel do Val. Configuration of the Brazilian Economic Thought in the nineteenth century. Tese (Doutorado). Universidade de São Paulo, Faculdade de Filosofia, Letras e Ciências Humanas, São Paulo, 2016.

This work analizes the configuration of the Brazilian Economic Thought in the nineteenth century. One of its aims is to argue that the existence of national economic thoughts is possible, instead of the point of view that comprehends Economic Theory as universal. Besides, we sustain the idea that the Brazilian Economic Thought can be approached considering its history in the nineteenth century, unlike a great amount of published material on the matter. Such material has as focus the approach on the twentieth century and the overwhelming underdevelopment issue.

Thus, we discuss the conception of ideas originated in Brazil and their interpretations, linking them to the Brazilian Economic Thought and its possibilities of approach.

It is intended, here, to discuss the universality and nationality of the Economic Theory, in a theoretical and methodological way. The aim is to deny the first and affirm the second one, proposing as reasonable and essential to consider Economic Theory and its thought regarding the specifities of every nation. The Brazilian Economic Thought flows from such idea and it is the result of analysis and, for many times, the adjustments and diffusion of theories produced in other contexts, concerning our particularities and peripheral conditions, are the elements that give originality and importance to it.

Taking this into consideration, we argue that the approach whose focus is the nineteenth century is achievable. This concept leads us to the organization, articulation and sistematization of what we call Brazilian Economic Though during the nineteenth century, based on references such as exerpts of thoughts and discussions from José da Silva Lisboa, the Viscount of Cairu, Political Economy teachings in Brazil, during the nineteenth century and the currency debate between papelistas and metalistas, emphasizing the ideas by Rodrigues Torres, Souza franco and Mauá.

Key-words: Brazilian economic Thought; nineteenth century; originality; diffusion; adjustment. 


\section{SUMÁRIO}

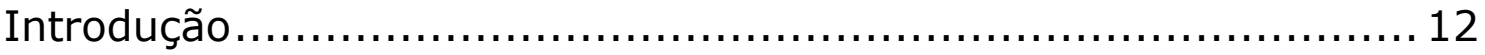

Capítulo 1:A formação histórico-ideológica do Brasil .................... 21

Capítulo 2:O Pensamento Econômico Brasileiro: perspectivas

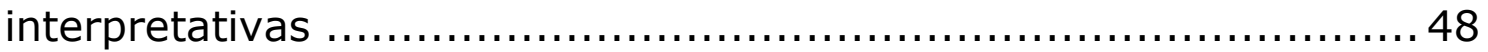

Capítulo 3:0 Pensamento Econômico Brasileiro no século XIX: teoria e expressçao prática ...................................................... 92

Conclusão ............................................................. 182

Referências Bibliográficas ........................................... 186 


\section{Introdução}

O certo é que vivemos postergando todo o postergável; talvez todos saibamos profundamente que somos imortais e que mais cedo ou mais tarde, todo homem fará todas as coisas e saberá tudo. (...)

Era o solitário e lúcido espectador de um mundo multiforme, instantâneo e quase intolerantemente preciso. (...)

Era-llhe muito difícil dormir. Dormir é distrair-se do mundo (...)

Suspeito, contudo, que não era muito capaz de pensar. Pensar é esquecer diferenças, é generalizar, abstrair. No mundo abarrotado de Funes não havia senão detalhes, quase imediatos.

Jorge Luís Borges em Funes, o memorioso do livro Fiç̧ões de 1944

Se procurar bem, você acaba encontrando

não a explicação (duvidosa) da vida, mas a poesia (inexplicável) da vida

Lembrete, Carlos Drummond de Andrade no livro Corpo de 1984

A tentação de iniciarmos esta tese com as epígrafes acima foi incontrolável. O fantástico conto Funes, o memorioso, de Jorge Luis Borges, permite inúmeras possibilidades de interpretação e associação. A história de Funes, um sujeito simples no interior do Uruguai, cuja vida se modificou para sempre após um tombo, é uma metáfora das mais apropriadas para os tempos atuais. Acometido da paralisia causada pelo acidente, adquiriu também uma curiosa doença, a incapacidade de esquecer. 
Contudo, apesar de sua memória precisa e milimétrica, Funes era incapaz de pensar, preso que sempre estava à precisão de todos os detalhes de tudo que acontecia. Solitário, era também incapaz de dormir, uma vez que dormir é desligar-se do tempo presente, distrair-se do mundo.

A metáfora com os dias de hoje é inevitável. Na era da informação, nada nos escapa. Tempo e espaço foram redefinidos, vivemos separados pela distância e pela espera de um click. Sutil e ironicamente, Borges aponta que a incapacidade de esquecer limita a capacidade de pensar, o que nos distancia do mundo e da realidade, cuja complexidade nos exige a habilidade de abstrair para entender e explicar os fenômenos.

Com as ciências humanas e sociais, especificamente a História e a Economia, não é diferente. A profusão de fontes, documentos, dados e informações pode levar historiadores e economistas à pretensa suposição de que seus trabalhos permitem-nos chegar à verdade inequívoca. À luz da metáfora de Borges, estaríamos, então, diante de um mundo repleto de Funes, onde a História e a Economia estariam reduzidas ao detalhe e as suas descrições. Ou, dito de outra forma, tanto a história quanto a economia tornar-se-iam cada vez mais descritivas e menos teóricas. É o que nos leva ao poema de Drummond.

Curto e preciso, nosso ilustre poeta nos lembra que, explicar o mundo e a vida é tarefa complicada. Não basta pesquisar, investigar e deter o máximo de informações que ofereçam subsídios para a sua explicação. Estes se manifestarão sempre através do inexplicável, por suas inúmeras possibilidades de interpretação, a poesia.

No campo da História Econômica esta questão se manifesta de forma singular, ao apontar para "abordagens que tornaram a esfera da economia auto-explicativa, ou seja, como se a sua compreensão fosse capaz de dar conta da complexidade dos fenômenos históricos". O mesmo poderia se observar com a ciência econômica, que " caminhou em direção 
a abordagens cada vez mais especializadas, tendo abandonado, no limite, o entendimento de que o seu objeto de reflexão são os fenômenos sociais". ${ }^{1}$

O resultado disso tem sido a valorização dos métodos quantitativos, das análises econométricas, em detrimento não só da teoria como da economia como conhecimento histórico. De certa forma, isso se manifesta na própria diminuição que disciplinas como a História Econômica e a História do Pensamento Econômico têm tido nos cursos de Ciências Econômicas. Tais disciplinas assumiram novas perspectivas, quantitativa e, por vezes, contrafactual, ${ }^{2}$ no caso da primeira, e excessivamente descritiva e despreocupada com a sua contribuição no campo da teoria, no caso da segunda.

Este movimento tem sua manifestação também na História, resultado da "fragmentação e da elevação dos fenômenos culturais à condição de forma; pela transferência para a dimensão simbólica do papel que fora antes ocupado pela economia". ${ }^{3}$ É o que François Dosse ${ }^{4}$ classificou como a História em Migalhas ao analisar como a Nova História dominou o método e o fazer histórico a partir de sua evolução, desde a Escola do Annales.

É o que leva José Jobson Arruda a propor uma História Econômica renovada, a partir da articulação entre a abertura de possibilidades, abordagens e assuntos oriundos da Nova história, e a valorização da teoria e da perspectiva mais totalizante e "que terá significado em si mesma e servirá aos propósitos de uma disciplina amplificada e de escopo

\footnotetext{
${ }^{1}$ ARRUDA, José Jobson de Andrade. Por uma História Econômica Renovada. Tempo. 38, 2015. No prelo

${ }^{2}$ Sobre a questão da história contrafactual ou New Economic History ver HOBSBAWN, E.

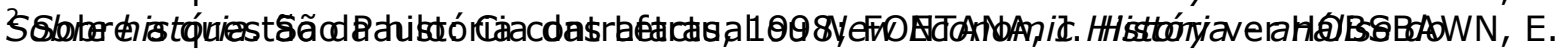
Sobre história. São Paulo: Cia das Letras, 1998; FONTANA, J. História - análise do passado e projeto social. Bauru: Edusc, 2004; FONTANA, J. A História do homens. Bauru: Edusc, 2004.

${ }^{3}$ ARRUDA (2015)

${ }^{4}$ DOSSE, François. A História em Migalhas. Bauru: EDUSC, 2003.
} 
alargado, espécie de micro análise a serviço de uma reflexão macro". ${ }^{5} \mathrm{E}$ que, portanto,

\begin{abstract}
"Em síntese, visualiza-se uma escrita histórica que não seja autocomplacente de si mesma, de sua criação científica ou estética. Consciente de que as circunstâncias produzem a história, do mesmo modo que a história produz as circunstâncias. Que vivenciamos o momento ideal para a escrita de uma história econômica inquieta, atenta às inovações do conhecimento, travejada na política e imbricada na cultura, que seja capaz de entender como os símbolos, verdadeiros hieróglifos sociais, simbolizam; por que meios se expressam 'para mediar os significados' e integrar a explicação histórica em qualquer uma de suas variedades, especialmente da história econômica". (ARRUDA, 2015)
\end{abstract}

Esta tese tem essa perspectiva, a que entende a História como "consciência crítica da experiência social da humanidade" ${ }^{6}$, bem como valoriza a relação dialógica entre a História e a Economia, entre a teoria e a História.

O que se vai ler aqui é um desafio de sistematizar uma História do Pensamento Econômico Brasileiro no século XIX, tendo como referência dois aspectos essenciais. De um lado, a possibilidade de um pensamento econômico nacional, brasileiro, e todas as consequências teóricas e metodológicas que disso decorre; de outro, a possibilidade de tal pensamento se manifestar no século XIX, partindo da discussão sistemática não só de personagens e temas que o compõe, como dos autores que discutiram tais personagens e temas sem a perspectiva da sistematização e do conjunto.

Discutir o Pensamento Econômico Brasileiro e sua condição de possibilidade é um desafio que remonta a Machado de Assis e sua

\footnotetext{
${ }^{5}$ ARRUDA (2015)

${ }^{6}$ ARRUDA, José Jobson de Andrade. Historiografia: Consciência Crítica da Produção Histórica. In: Historiografia: teoria e prática. São Paulo: Alameda, 2014. p.51.
} 
discussão a respeito da literatura brasileira no final do século XIX ${ }^{7}$. No artigo publicado na revista $O$ Novo Mundo $^{8}$, Machado percebe que se formava na literatura brasileira certo instinto de nacionalidade que representava a consideração dos aspectos característicos da realidade e cultura brasileira na produção de textos.

"Quem examina a atual literatura brasileira reconhece-
Ihe logo, como primeiro traço, certo instinto de
nacionalidade. Poesia, romance, todas as formas
literárias do pensamento buscam vestir-se com as
cores do país, e não há negar que semelhante
preocupação é sintoma de vitalidade e abono de futuro.
(...) Interrogando a vida brasileira e a natureza
americana, prosadores e poetas acharão ali farto
manancial de inspiração e irão dando fisionomia própria
ao pensamento nacional. Esta outra independência não
tem Sete de Setembro nem campo de Ipiranga; não se
fará num dia, mas pausadamente, para sair mais
duradoura; não será obra de uma geração nem duas;
muitas trabalharão para ela até perfazê-la de todo".
(Machado de Assis, 1873)

Evidentemente que não é nosso objetivo, aqui, por tratar-se de tema complexo e distante do escopo desta tese, explorar todas as simbologias e significados do texto do grande Machado de Assis, no entanto, partindo de uma perspectiva semelhante à tal reflexão, podemos considerar o Pensamento Econômico Brasileiro a partir de sua manifestação como reflexão e interpretação a respeito da realidade e da economia brasileira.

Naturalmente esta questão está relacionada a uma discussão mais ampla e que diz respeito a possibilidade da existência de pensamentos

\footnotetext{
${ }^{7}$ Machado de Assis. Instinto de Nacionalidade, publicado originalmente em $O$ Novo Mundo, 24/03/1873 e posteriormente em Obra Completa de Machado de Assis, Rio de Janeiro: Nova Aguilar, vol. III, 1994.

${ }^{8}$ O Novo Mundo foi um periódico liberal, progressista e abolicionista publicado entre 1870 e 1879 em Nova York para ser distribuído no Brasil. Ao que tudo indica, o artigo foi encomendado a Machado de Assis pelo editor do periódico José Carlos Rodrigues. Ver ASCIUTTI, Monica Maria Rinaldi. Um Lugar para o periódico O Novo Mundo (Nova Iorque, 1870-1879). Dissertação de Mestrado. Literatura Brasileira. FFLCH-USP, 2010; BERGAMINI, Atilio. "Instinto de nacionalidade" na imprensa liberal. Machado Assis em Linha, vol.6 no.12 Rio de Janeiro Dec. 2013.
} 
econômicos nacionais e da consideração ou não da universalidade da teoria econômica.

Além disso, e no que diz respeito específico ao nosso trabalho, consideramos a questão a partir do Brasil no século XIX. Isto remonta à outra questão: o enfoque tradicional da maioria dos trabalhos sobre Pensamento Econômico Brasileiro no século XX e nas questões relativas ao desenvolvimento econômico.

Alguns temas têm referências obrigatórias e, no caso do Pensamento Econômico Brasileiro, trata-se do livro homônimo de Ricardo Bielschowsky, cujo recorte temporal é século XX. O autor parte de uma metodologia inspirada em Schumpeter e na ausência de uma produção analítica ou teórica no Brasil, estuda o seu viés pratico, marcado por uma política econômica com uma finalidade específica. Trata-se de entender que a especificidade brasileira de meados do século passado e sua necessidade de transformação condicionavam o debate econômico, pouco teórico, mais voltado para ação. Esta seria uma das características principais do pensamento econômico brasileiro entre 1930 e 1980 para o autor. Diante disso, Bielschowsky avalia e debate a industrialização e o desenvolvimentismo na visão de algumas correntes de pensamento que ele mesmo estabelece, a partir de sua definição e conceitualização do que é o desenvolvimentismo.

Este trabalho clássico inspirou e inspira diversos outros cujo recorte temporal e analítico é parecido. Evidentemente que não é nosso objetivo aqui argumentar que Bielschowsky e outros autores, que trataram a respeito do tema, desconhecem a realidade brasileira e o seu pensamento econômico no século XIX, entretanto, é gritante a predileção pelo estudo do século $X X$, o que se justifica pela grande preocupação que temos com relação ao desenvolvimento econômico e a industrialização. Por outro lado, indiretamente tal postura ignora a possibilidade de um pensamento econômico brasileiro em períodos anteriores. 
A abordagem do Pensamento Econômico Brasileiro no século XIX, além de possível, é necessária. Reconhecemos a importância e a centralidade da industrialização e do desenvolvimento como fundadores de um pensamento econômico nacional, cujo principal expoente é Celso Furtado, contudo, é preciso resgatar as ideias e o Pensamento Econômico Brasileiro no século XIX como uma forma não só de melhor compreender nossa história econômica e social, mas também como uma possibilidade de melhor compreender nossa formação cultural e de identidade. Trata-se sobretudo de entender as inter-relações entre a formação nacional, sua especificidade e a formação do Pensamento Econômico Brasileiro.

Este é o objetivo desta tese. Para tanto, retomamos Machado de Assis no que há de mais essencial em seu texto de 1878,

"Não há dúvida que uma literatura, sobretudo uma
literatura nascente, deve principalmente alimentar-se
dos assuntos que Ihe oferece a sua região; mas não
estabeleçamos doutrinas tão absolutas que a
empobreçam. O que se deve exigir do escritor antes de
tudo, é certo sentimento íntimo, que o torne homem do
seu tempo e do seu país, ainda quando trate de
assuntos remotos no tempo e no espaço". (Machado de
Assis, 1878)

Ou seja, à luz da perspectiva machadiana, é preciso refletir sobre o Pensamento Econômico a partir dos problemas e das especificidades nacionais, mas também a partir da própria realidade de seus personagens, produtos que são de um tempo histórico.

Assim, abordamos nosso tema por um viés teórico, mas também prático. Sendo que, por prático entendemos, "o tratamento do modo como os acontecimentos históricos foram interpretados" e "dos circunstanciamentos mais gerais que estabelecem a conexão entre autorobra-meio, ou seja, uma relação produzida no interior da vida social em 
sua mais ampla acepção" 9 . Trata-se, portanto, da Historiografia em sua forma crítica ${ }^{10}$, como propõe José Jobson Arruda,

"Por que os historiadores escreveram o que escreveram? Por que o fizeram? Que influência as interpretações tiveram sobre 0 desenvolvimento histórico ulterior? São essas as questões de fundo que movem a história por meio da reconceituação da escrita historiográfica, especialidade que se aloja mais propriamente no campo da reflexão intelectual e que não pode ser enclausurada em temporalidades estanques, que recusa a unidirecionalidade do fluxo temporal, voltada à apreensão do seu direcionamento múltiplo, entrelaçamento e simultaneidade, cuja percepção e apanágio do ser pensante, do ser no tempo, com sensibilidade para o tempo, que em termos imagéticos não se identifica com 0 rio de sentido unívoco, e sim com as nuvens de fluxos múltiplos". (ARRUDA, 2014, p.57-58)

Esta tese está dividida em três capítulos. No primeiro capítulo, $A$ formação histórico-ideológica do Brasil, discutimos a herança ibérica, as interpretações do Brasil e a sua relação com a formação das ideias e a formação do Brasil. Aqui, um parênteses se faz necessário, quando nos

\footnotetext{
${ }^{9}$ ARRUDA, José Jobson de Andrade. Territórios Historiográficos Contemporâneos: por uma nova síntese histórica. In: Historiografia: teoria e prática. São Paulo: Alameda, 2014. p.66.

${ }^{10}$ A melhor expressão prática deste método, além dos trabalhos já citados de José Jobson Arruda, encontramos nos trabalhos de Roberto Pereira Silva sobre Celso Furtado. Em O Jovem Celso Furtado, o autor discute os textos da juventude de Furtado, imergindo sobre a sua obra e a multiplicidade de seus temas de interesse até o encontro e a seleção da Economia como objeto de estudo com a tese de doutorado sobre a Economia colonial brasileira. Para tanto, estabelece um paralelo entre a tese e o clássico Formação Econômica do Brasil, mostrando as rupturas entre as duas e como Furtado adéqua as suas perspectivas a partir da sua participação na CEPAL e da forma como apreende a questão do desenvolvimento e do subdesenvolvimento. Já em sua tese de doutorado, recentemente defendida, Roberto Pereira Silva amplia a sua discussão para entender a relação entre História e Teoria Econômica na obra de Celso Furtado entre 1948 e 1959. Analisando os trabalhos econômicos de Furtado, durante a década de 1950, o autor procura entender como Furtado se inseria no debate econômico da época e como, aos poucos, foi formulando o seu método de análise a partir de uma formulação teórica que conjugava a história e a teoria econômica. Finalmente, o autor analisa Formação Econômica do Brasil como uma resposta aos desafios teóricos e metodológicos aos quais enfrentou para interpretar a realidade brasileira e transformá-la a partir de tais diagnósticos. Ver SILVA, Roberto Pereira. O Jovem Celso Furtado; história, política e economia (1941-1948). Bauru: EDUSC, 2011 e SILVA, Roberto Pereira. Celso Furtado, Entre a História e a Teoria Econômica (1948-1959): uma interpretação historiográfica. Tese de Doutorado em História Econômica. FFLCH-USP, São Paulo, 2015.
} 
referimos à formação ideológica, estamos nos referindo ao sentido de acumulação de ideias e não de ideologia como falsidade ou expressão de uma determinada visão de mundo, desse modo, buscamos estabelecer uma relação entre a discussão política e a econômica, entre os elementos que marcam a formação da identidade, da cultura, da política e a formação do pensamento econômico no Brasil.

No segundo capítulo, O Pensamento Econômico Brasileiro: perspectivas interpretativas, procuramos fazer uma discussão teóricometodológica a respeito da possibilidade de um pensamento econômico nacional, com ênfase no Brasil e especificamente no século XIX. Trata-se, essencialmente, de entender que a Economia, como ciência social, não pode ser compreendida sem as especificidades que caracterizam cada tempo e lugar e de negar a sua pretensão universalizante.

No último capítulo, O Pensamento Econômico Brasileiro no século XIX: teoria e expressão prática, tentamos estabelecer uma síntese do que consideramos ser o Pensamento Econômico Brasileiro no século XIX, entendendo a sua formação e desenvolvimento e propondo uma maneira de abordar a questão. Para tanto, esboçamos uma construção teórica que justificasse a abordagem do tema no período indicando, continuando e concluindo uma discussão iniciada no capítulo anterior. Ademais, procuramos articular e organizar a produção historiográfica que, de alguma forma, aborda algum aspecto do Pensamento Econômico Brasileiro no século XIX dando a ela unidade e sentido. 


\title{
Capítulo 1
}

\section{A formação histórico-ideológica do Brasil}

\begin{abstract}
"Encheu-se-Ihe a fantasia de tudo que achava nos livros, assim de encantamentos, como pendências, batalhas, desafios, feridas, requebros, amores, tormentas, e disparates impossíveis; e assentou-se-Ihe de tal modo na imaginação ser verdade toda aquela máquina de sonhadas invenções que lia, que para ele não havia história mais certa no mundo." Miguel de Cervantes em D. Quixote de La Mancha

"Como as coisas humanas não são eternas e vão sempre em declinação desde o princípio até ao seu último fim, especialmente as vidas dos homens" Miguel de Cervantes em D. Quixote de La Mancha

"Não queria compor outro Quixote - o que é fácil -, mas o Quixote." Jorge Luis Borges no conto Pierre Menard, autor do Quixote, do livro Ficções
\end{abstract}

As epígrafes acima se referem a dois dos maiores escritores de todos os tempos. Miguel de Cervantes e Jorge Luis Borges, autores de tempos distintos, mas de obras igualmente complexas e repletas de metáforas e paráfrases possíveis para se entender e explicar a realidade.

A magnífica obra de Cervantes aborda a história de um fidalgo espanhol que, de tanto ler livros de cavalaria, enlouquece, se autodetermina e autodenomina o cavaleiro Dom Quixote de La Mancha e passa a percorrer o mundo a corrigir as suas mazelas. $O$ personagem, no auto de seus devaneios, procura reviver os tempos gloriosos das Cruzadas, onde a Espanha teve papel central na batalha pelo catolicismo em todo mundo. É uma obra também de intensa ironia. Em finais do século XVI a realidade europeia era outra. Como evidenciado pelos questionamentos protestantistas e as reformas católicas, o mundo estava se transformando, se desencantando dos valores e crenças medievais. A ironia da obra é a ironia da própria Espanha e porque não da própria região mediterrânea, tão bem retratada por Fernand Braudel.

No conto de Borges, por outro lado, não há propriamente uma história, mas a descrição e um comentário da obra de um escritor francês 
fictício, Pierre Menard, que tentou reescrever o Quixote de Cervantes. Não reescrever a obra do escritor espanhol adaptando-a ao seu tempo, mas escrevê-la novamente, com as mesmas palavras, pontos e vírgulas; não se tratava de copiá-la, mas sim de reescrevê-la. A diferença que parece sutil ou inexistente é essencial, pois Menard tentou reproduzir o ambiente, os costumes e o tempo de Cervantes para assim poder escrever a mesma obra, com a mesma estrutura e as mesmas frases. O enredo do conto é extremamente complexo e foi tema de diversas interpretações e discussões literárias. É um dos trabalhos mais importantes do escritor argentino conhecido por seus contos-ensaios imaginários, filosóficos e históricos. Não queremos aqui explorar as inúmeras possibilidades interpretativas que o conto oferece, desde os questionamentos sobre os significados que atribuímos a diversas leituras e livros, bem como o significado que atribuímos à literatura. O que nos interessa aqui é perceber um tema costumeiro na obra de Borges, o anacronismo. Seria impossível reescrever o Quixote de Cervantes porque é impossível restabelecer o tempo em que o ele viveu, suas especificidades e circunstancias. O tempo é implacável.

Menard e Quixote se assemelham e se aproximam através da ironia de seus destinos. Um enlouqueceu e tentou viver um tempo que a história já havia superado, o da grande Espanha territorialista, agente conquistadora e disseminador do catolicismo pelo mundo. Outro imaginou ser possível recriar a história e manipular o tempo, e essa seria a grande dificuldade da vida. O grande dilema do escritor, ou do próprio homem, seria recriar e reviver o tempo e a história, o livro no caso do escritor, ou a vida, no caso do homem, seria uma circunstância.

Mas por que recorrer a esta epígrafe para retratar a formação do Brasil bem como as ideias no Brasil? Há um consenso entre todos nós que a tradição ibérica tem um peso importante sobre nossa história. Nada melhor que Dom Quixote para ilustrar e metaforizar esta tradição. O personagem de Cervantes é a própria metáfora da sociedade ibérica no período de desencantamento do mundo, no período da colonização da 
América, é o retrato da Ibéria da tradição, do barroco como filosofia da tradição que tanto nos marca.

Ao longo das páginas seguintes procuramos tentar entender o peso da tradição ibérica em nossa formação, procuramos interpretar e discutir como a historiografia aborda tal tema e como podemos a partir daí refletir sobre a formação das ideias, mais precisamente as econômicas, no país.

Discutir as tradições e a cultura ibérica no mundo contemporâneo sempre nos remete a Fernand Braudel. Sua obra "O Mediterrâneo e o Mundo Mediterrânico na Época de Filipe II", publicada em 1949, retrata o mundo mediterrâneo em um momento essencial para a compreensão da história moderna. Filipe II, rei da Espanha entre 1555 e 1598, tentou continuar o projeto de seu pai, Carlos $V$, que tentou estabelecer na Europa um projeto de modernidade com o objetivo de manter estruturas sociais e de poder anacrônicas, através da ideia de uma monarquia universal; o século XVI, no entanto, é um século de transformações.

Enquanto a Europa conhecia as ideias de Lutero, Copérnico e questionava os valores medievais, Carlos $\mathrm{V}$ tentava impor um projeto anacrônico, a partir de instituições que já não faziam tanto sentido como o papado e o conceito de império. O século XVI na Europa é um século de negação dos valores medievais, da ideia do universal, da afirmação dos Estados, projetos e religião nacionais. Filipe II buscou continuar o projeto do pai, mas, em meados do século, a Europa já era outra e a derrota da Invencível Armada em 1588 foi um episódio marcante da decadência do poderio espanhol e ibérico e de certo projeto de modernidade.

Se na península ibérica encontramos a raiz da modernidade a partir do pioneirismo na unificação nacional com Espanha e Portugal, é também na Ibéria que encontramos o fim de uma era, a medieval. Não é nosso intuito aqui conceituar modernidade, mas por ela podemos entender a superação do mundo medieval a partir dos valores iluministas. É certo, entretanto, que a modernidade ibérica voltou-se para o passado, procurou reformar os valores através da manutenção das estruturas do passado e por isso mostrou-se parcial, limitada, aprisionada e conservadora. Logo, 
como nos mostra brilhantemente Braudel, refletiu a própria decadência da região mediterrânea durante o século XVI e o reinado de Filipe II. ${ }^{11}$

Entender como este período reflete de forma decisiva o que há de mais marcante na tradição e na cultura ibérica é fundamental. $O$ trabalho de Rubem Barboza Filho, Tradição e Artifício, nos parece essencial ${ }^{12}$. O autor procura entender o que é a tradição ibérica e como o iberismo e o barroco influenciaram de forma decisiva a formação das nações da América ibérica. Este trabalho pode ser explorado e discutido em vários aspectos. Em um primeiro momento, nos interessa explorar a obra a partir do período histórico abordado nos parágrafos anteriores.

Barboza Filho procura apresentar no início de seu trabalho qual seria a tradição ibérica. Ao final da Idade Média, a Península Ibérica ocupava um lugar central na cena mundial e foi personagem principal dos mais significativos episódios da época, da expulsão dos muçulmanos ao desbravamento dos mares e a exploração e o "descobrimento" de novos "mundos". Os ibéricos se imbuíram da missão da universalização e na defesa da divindade e da fé.

Discutindo os Séculos de Ouro da Ibéria, o autor argumenta que a tradição é um elemento essencial de sua cultura, costumes e sociedade, ora responsabilizada pelas mazelas do presente, ora evocada para a manutenção de estruturas e privilégios. Temos aqui clara a ideia da modernidade aprisionada, da reforma do mundo medieval a partir da reforma dos valores, porém ancorado sobre a mesma estrutura social e de poder. Assim,

"Na verdade, a Ibéria dos Séculos de Ouro e dos séculos anteriores é uma vertigem, um labirinto, uma polissemia constante e um enigma renovado. Sua natureza parece dotada de extrema plasticidade. Aceita e acolhe os significados históricos que lhe são permanentemente conferidos, ao mesmo tempo que teima em esconder um núcleo fugidio e inacessível.

\footnotetext{
${ }^{11}$ BRAUDEL, Fernand. O Mediterrâneo e o Mundo Mediterrânico no Época de Filipe II. São Paulo: Martins Fontes, 1983. 3 Vol.

12 BARBOZA FILHO, Rubem. Tradição e artifício: iberismo e barroco na formação americana. Belo Horizonte: Ed UFMG; Rio de Janeiro: IUPERJ, 2000.
} 
Parte desta polissemia deve-se à forma sistematicamente dramática com que a tradição é capturada para o presente pelos próprios ibéricos. Ora ela é responsabilizada pelo atraso material e cultural de Espanha e Portugal, ora transmuta-se em fonte de sentido para restauração de corte nacional e identitário, ora é nela que se buscam as bases para programas de democratização das nações que nasceram em seu interior. O mesmo ocorre nos países ibero-americanos. Para todos, a tradição é ainda elemento vivo, "virtualmente presente" para usar uma expressão de Mannheim, mesmo que se deixe vislumbrar em fragmentos na superfície da vida social. Ela é um protagonista do presente, destinada a ser reiterada, explorada, saqueada ou destruída. Cadáver insepulto a travancar o nosso caminho, ou uma espécie de Lázaro que deve sempre voltar à vida para a nossa plena identidade, ela é ainda horizonte do nosso presente." (BARBOZA FILHO, 2000, p.32)

O autor avança na discussão a respeito dos Séculos de Ouro da Ibéria procurando entender como a região pioneira da modernidade viu-se decadente diante da concretização das transformações sociais e econômicas provenientes do final da Idade Média. Para tanto, discute trabalhos de Perry Anderson, Antonio Manuel Hespanha, Fernand Braudel, Giovanni Arrighi e Richard Morse ${ }^{13}$. Dessa forma, analisa a formação e consolidação do absolutismo nas nações ibéricas. Nesse sentido nos mostra como tais sociedades consolidaram privilégios de seus fidalgos e nobres, consolidaram práticas políticas medievais, negaram os pressupostos de centralização e racionalização administrativa e política, privilegiaram e defenderam a fé em detrimento da razão calculista, bem como a expansão territorial e populacional (que beneficiava e alimentava uma sociedade de corte tradicional) em detrimento de transformações estruturais.

\footnotetext{
${ }^{13}$ Ver ANDERSON, Perry. Linhagens do Estado absolutista. São Paulo: Brasiliense, 1989; BRAUDEL (Op. Cit); HESPANHA, A.M. As vésperas do Leviathan: instituições e poder político. Portugal - século XVII. Coimbra: Livraria Almedina, 1994; ARRIGHI, Giovanni. O longo século $X X$ - Dinheiro, poder e origens de nosso tempo. Rio de Janeiro: Contraponto, 1996; MORSE, Richard. O espelho de Próspero: cultura e ideias nas Américas. São Paulo: Companhia da Letras, 1988.
} 
Nos autores acima citados, Barboza Filho busca inspiração para elucidar o eixo central do seu trabalho, a ideia de que a Ibéria se ergueu como alternativa civilizatória do Ocidente ao estabelecer a prioridade do "espaço sobre o tempo, do movimento no espaço sobre o movimento da história, da permanência sobre a mudança, estimulada e sustentada por premissas especificas e particulares sobre a vida, a sociedade e suas finalidades". (BARBOZA FILHO, 2000, p. 101)

Assim, para o autor, a Ibéria, apesar de seu pioneirismo na unificação territorial e consolidação dos Estados-nação, bem como sua liderança na vitória sobre o Oriente, não incorpora os valores da modernidade incorporados por outras regiões europeias. O iluminismo, 0 desencantamento do mundo e a valorização das ciências naturais proporcionaram nestas regiões o avanço do capitalismo enquanto os ibéricos permaneceram aprisionados em outro projeto modernizante e de civilização e se veem obrigados a aceitar, de forma subordinada, um projeto de modernização e civilizatório que the parece estranho. Este dilema marcou e ainda marca os povos ibéricos e de origem ibérica. A estrutura da sociedade e os valores que se impuseram às sociedades a partir da consolidação do capitalismo em escala global the parecem distantes.

Mas como podemos refletir a respeito de tais questões quando nosso objeto é o Brasil?

Compreender o Brasil é, antes de tudo, um desafio à crítica e à ação daqueles que acreditam que é possível mudar e construir um futuro melhor. Desafio esse, que exige, de alguma forma, um olhar sobre o processo de formação e constituição do Brasil a partir da análise do Estado e da cultura.

A historiografia já produziu diversas obras e estudos que ajudam a compreender o tema. Podemos destacar o grande Sérgio Buarque de Holanda, cujo pioneirismo na interpretação Weberiana da história do país pode ser dividido com Raymundo Faoro. Na mesma linha Weberiana podemos recordar os trabalhos de Simon Schwartzman e Fernando 
Uricoechea. Não há como falar em trabalhos clássicos sem citar Caio Prado Junior e Gilberto Freyre. Menção importante também deve ser feita aos estudos de Ilmar Mattos e José Murilo de Carvalho, cabendo lembrança, ainda, à interpretação de Richard Morse.

Comum entre todos esses trabalhos é a preocupação em interpretar o país, iluminando e elucidando a compreensão do presente. É certo que o processo de construção do Brasil (formação do Estado e da cultura) é dos assuntos mais fundamentais à compreensão de nossa história política e econômica, fundamental para se entender as raízes do pensamento brasileiro.

Talvez seja consenso entre historiadores e cientistas sociais que um estudo que pretenda refletir sobre o país deva, necessariamente, passar pela análise de três obras clássicas essenciais. Casa Grande e Senzala de Gilberto Freyre, publicado em 1933, Raízes do Brasil de Sérgio Buarque de Holanda publicado em 1936 e Formação do Brasil Contemporâneo de Caio Prado Junior publicado em 1942 são trabalhos pioneiros na tentativa de interpretar o Brasil e entender as suas origens. ${ }^{14}$ Como bem aponta Antonio Cândido, refletem o movimento modernista, inaugurado pela Semana de 1922 e que tem na década de 1930 um momento importante, marcado pela esperança política sintetizada na Revolução de Outubro e nas mudanças econômicas e sociais pelas quais o país passava. Tais trabalhos, como bem lembram Novais e Arruda ${ }^{15}$, inauguram uma tradição no pensamento social brasileiro, a incessante busca por nossas raízes, pelas características essenciais de nossa identidade. A necessidade de compreensão do passado para superação do presente, para o desenvolvimento e modernização da sociedade brasileira.

\footnotetext{
${ }^{14}$ Ver CANDIDO, Antonio, Literatura e Sociedade., São Paulo: Publifolha, 2000 e CANDIDO, Antonio. O Significado de Raízes do Brasil. In: HOLANDA, Sérgio Buarque de. Raízes do Brasil. São Paulo: Cia das Letras, 1995.

${ }^{15}$ NOVAIS, Fernando A.; ARRUDA, Maria Arminda do Nascimento. Apresentação: revisitando intérpretes do Brasil. Revista USP, (38): 6-9, Junho/Agosto, 1998.
} 
O trabalho de Gilberto Freyre ${ }^{16}$, de 1933 , tem forte influência da sociologia norte-americana e, já a partir do título, nos sugere seu objetivo central: entender a formação da família brasileira sob o regime da economia patriarcal. Assim, uma de suas preocupações centrais é tentar entender a miscigenação e o seu papel na formação do povo e da cultura brasileira.

Para o autor, a relação do branco e das demais raças no Brasil foi condicionada por dois fatores primordiais: de um lado, a monocultura e o latifúndio, de outro, a ausência de mulheres brancas na colônia. O primeiro fator impôs um sentido aristocratizante e segregador na relação entre senhores e escravos, enquanto o segundo impôs a mistura das raças. Dessa contradição nasce, para Freyre, uma democracia social. Dito de outra forma, daí nasce o Brasil. Assim, essa contradição na relação entre as raças marcará a formação da sociedade em duas polaridades: em uma, a diferença social ou a Casa-grande, na outra a mistura, a miscigenação, a senzala, que acabaria impondo uma relação mais suave entre "opressores" e "oprimidos".

Desse encontro de raças e culturas surge a família patriarcal e todo um sistema econômico, social e político que organizaria a sociedade. Assim, a família teria sido o eixo central da colonização brasileira em detrimento do Estado ou das companhias de comércio, eixos da colonização espanhola e holandesa respectivamente. O patriarcalismo, para o autor, possibilitou unidade para o país e permitiu a formação de uma cultura brasileira, diferente e não um simples prolongamento da europeia. O brasileiro seria o mestiço adaptado aos trópicos. Essencial é perceber que, para Gilberto Freyre, as relações raciais no Brasil seriam relativamente harmônicas.

Casa Grande e Senzala gerou diversas interpretações. De um lado, aqueles que procuraram negar a ideia da democracia racial e ressaltar a relação de opressão e violência entre senhores e escravos. De outro,

\footnotetext{
${ }^{16}$ FREYRE, Gilberto. Casa-grande \& senzala: formação da família brasileira sob o regime da economia patriarcal. 51a Ed. Ver., São Paulo: Global, 2006.
} 
aqueles que, a partir de tal ideia, buscaram explicar uma escravidão benevolente, bem como as peculiaridades da relação senhor e escravo no Brasil e o sentido e a organização do escravismo no país ${ }^{17}$.

Evidentemente esta não é a nossa preocupação central. Gilberto Freyre parece valorizar, de certa forma, o passado colonial, logo, tudo que o caracteriza, diferenciando-se, assim, da maior parte dos intelectuais de sua geração. Por outro lado, seu trabalho chama atenção para a inegável realidade cultural brasileira, formada a partir da miscigenação e do patriarcalismo. A despeito de posições conservadoras, é essencial refletir sobre esta contribuição. Se, por um lado, o passado colonial e a herança ibérica nos marcam profundamente, como veremos mais adiante, por outro, a mistura de raças e a família patriarcal também são elementos essenciais na compreensão do Brasil e da cultura brasileira.

Três anos após a publicação da obra do sociólogo pernambucano, em 1936, Sérgio Buarque de Holanda publica Raízes do Brasil ${ }^{18}$. A obra busca através do passado, enxergar o futuro a partir da compreensão da identidade nacional. De inspiração Weberiana, o texto busca a essência do homem brasileiro. O "homem cordial" é apresentado por Sérgio Buarque como fruto da nossa história, marcada pela colonização portuguesa e por uma estrutura econômica, social e política influenciada pelo patriarcalismo e pela escravidão.

Para o autor, a cultura ibérica é marcada pela negação ao trabalho e à racionalização da vida social, o que resulta em uma estrutura social frágil que necessita de uma força exterior "respeitável e temível" para manter a coesão da sociedade. Através da colonização, o Brasil herda esse traço da tradição ibérica que resultará em uma sociedade marcada pela estrutura rural e patriarcal, fruto da personalidade "aventureira" do português, avesso ao trabalho e ávido pela busca do ganho fácil e imediato (traduzido na escolha do modelo de produção ancorado no latifúndio e na escravidão).

17 Sobre esta questão ver GORENDER, Jacob. A Escravidão Reabilitada., São Paulo: Ática, 1991. E SCHWARTZ, Stuart S. Escravos, roceiros e rebeldes. Bauru, SP: EDUSC, 2001. ${ }^{18}$ HOLANDA, Sérgio Buarque de. Raízes do Brasil. São Paulo: Cia das Letras, 1995. 
Dessa forma, o "homem cordial" é a síntese da herança ibérica, ou da forma como tal cultura se adaptou ao Brasil. Isso irá se refletir de forma decisiva na formação do Estado. O meio rural e patriarcal irá marcar tal processo, centrado no predomínio dos valores pessoais e particulares em detrimento da impessoalidade e do racionalismo. 0 resultado é um Estado marcado pela confusão entre o público e o privado, pela invasão do público pelo privado, pela ausência dos princípios da racionalidade calculista.

Assim, para Sergio Buarque, a herança ibérica gerou uma modernização inautêntica no Brasil. As formulas modernizantes oriundas da Europa e da América do Norte nunca se ajustaram da melhor maneira ao país. Se no velho continente as reformas liberais serviram para acabar com o poder da aristocracia em favor de uma sociedade e Estado burguês, no Brasil tais reformas partiram da própria aristocracia mantendo seu poder e privilégios.

Logo, para o autor, é a partir da constatação e consideração de tal herança ibérica que se deveria partir para o estabelecimento da democracia e coesão social no Brasil. Nesse sentido, ao mesmo tempo em que se rejeita a herança ibérica, se prega uma alternativa que não seja simples cópia de um modelo que pode nos parecer inautêntico e estranho.

Em uma linha diferente das de Sergio Buarque e Gilberto Freyre, Caio Prado Junior apresenta uma outra interpretação a respeito da realidade brasileira ${ }^{19}$. No clássico Formação do Brasil Contemporâneo, de 1942, o autor procura entender a influência da colonização sobre a formação nacional a partir de uma perspectiva marxista. Assim, o primeiro capítulo Sentido da colonização tem importância central no trabalho.

Para Caio Prado, a colonização foi um capítulo do desenvolvimento do comércio europeu, dessa forma, era ditada pela acumulação do capital comercial na Metrópole. Assim, para ele, a colonização teve finalidade comercial, que definiu todas as estruturas coloniais brasileiras.

\footnotetext{
${ }^{19}$ PRADO JUNIOR, Caio. Formação do Brasil Contemporâneo: colônia. São Paulo: Cia das Letras, 2011.
} 
Assim, o sentido da colonização foi a extração de lucros comerciais para a Metrópole através da Colônia. A noção de sentido é fundamental na obra do autor. Ela confere a ideia de direção permanente e continua, o sentido determina a totalidade. Logo, o sentido da colonização determinou toda a organização social e econômica do Brasil ${ }^{20}$. Para Caio Prado, a independência do país rompeu os laços de dominação política entre a metrópole e a colônia mas não interrompeu o sentido e a organização econômica do país, voltados para fora. Assim, qualquer mudança dependeria da revolução e da transformação radical das estruturas.

Para Bernardo Ricupero ${ }^{21}$,

"A grande contribuição de Caio Prado Jr. ao estudar a colônia é mostrar que se pode entender o Brasil sobretudo pelo "sentido" que assumiu a colonização no país. Por ter compreendido esse sentido, de empreendimento comercial voltado para a produção de gêneros tropicais para o mercado externo - pôde revelar o que foi a essência da experiência colonial brasileira. Assim, o retrato que fornece da colônia não é de mero amontoado de eventos e características combinados aleatoriamente, mas de uma certa sociedade que, mesmo problematicamente, começa a se formar." (RICUPERO, 2008, p. 147)

Portanto, o sentido da colonização marcou de forma decisiva toda a formação nacional desde a organização do Estado, até a formação das ideias e do pensamento. Mais à frente exploraremos melhor a questão.

Raymundo Faoro é outro intelectual que tentou interpretar o Brasil e explicar o processo de formação do Estado. Seu trabalho mais importante, Os Donos do Poder: formação do patronato político brasileiro ${ }^{22}$, foi publicado pela primeira vez em 1958. A obra tem forte inspiração Weberiana, utilizando-se da noção de estamentos burocráticos para compreender a evolução histórica do país. A partir de uma análise a

\footnotetext{
${ }^{20}$ Ver NOVAIS, Fernando A. Caio Prado Jr. na historiografia brasileira. In: MORAES, R. e outros (orgs.). Inteligência brasileira, São Paulo, Brasiliense,1986.

${ }^{21}$ RICUPERO, Bernardo. Sete lições sobre as interpretações do Brasil. São Paulo: Alameda, 2008.

22 FAORO, Raymundo. Os Donos do Poder: formação do patronato político brasileiro. São Paulo: Publifolha, 2000.
} 
respeito das origens do Estado português, passando pela colonização, independência, Império, República até chegar ao Estado Novo, o autor ressalta a permanência de uma estrutura política e social ancorada no patrimonialismo e na sociedade estamental. Para Faoro, a história de Portugal e do Brasil sempre refletiu a subordinação da sociedade ao Estado.

Para o autor, as origens do nosso sistema político estariam em Portugal, cuja estrutura de dominação patrimonial impediu a formação de uma nobreza autônoma abaixo do rei, gerando subordinação e dependência na nomeação de cargos e distribuição de recursos. Nesse sentido, o sistema político português não se enquadraria ao tipo ideal Weberiano de dominação patrimonial feudal, mas sim a um tipo de dominação patrimonial estamental, não feudal em suas origens. Faoro constrói um tipo ideal diferente do proposto por Weber, dotado de características próprias, como a confusão entre o público e o privado na administração do Estado e a administração do território, não como propriedade de um senhor, mas do estamento. Sendo que este, dotado de características aristocráticas, se burocratiza, modernizando-se com 0 Estado. Paro o autor, portanto, o patrimonialismo adquiriria uma especificidade ibérica. Diferentemente do que propõe a analise Weberiana, os estamentos cresceram fora da ordem feudal sem quebrar, necessariamente, a ordem patrimonial.

Esta estrutura patrimonialista estamental acaba por influenciar o pensamento e o sistema político brasileiro perpetuando-se por toda história desde a sua origem ibérica. Dessa forma, Faoro mostra a grande influência e força exercida por um poder central, cujo exercício se dava em causa e benefício próprio. O domínio da máquina política e administrativa do país levava aos benefícios privados de poder, prestígio e riqueza, portanto, caracterizando uma confusão e mistura de interesses públicos subjugados a interesses privados e particulares. Assim, a forma como se constitui o Estado no Brasil, para o autor, irá marcar 
decisivamente o pensamento político que procura justificar esse tipo de dominação patrimonialista.

Em texto mais recente ${ }^{23}$, Faoro se questiona sobre a existência de um pensamento político brasileiro. A resposta dada por ele, abarca, ponto de vista histórico, o pensamento português, bem como, do ponto de vista filosófico, as apropriações das doutrinas liberais. Segundo o autor, o que permite afirmar que há um pensamento político brasileiro é a existência de um quadro cultural autônomo, constituído a partir de uma realidade social específica, que permite a sua constituição e que se consolidará sob forte determinação e influência de paradigmas e modelos culturais importados. A dificuldade de emancipação intelectual é uma marca do universo mental no Brasil. O desenvolvimento de um pensamento político nacional autônomo sempre foi limitado.

A apropriação do Liberalismo no Brasil sempre esteve limitada aos interesses políticos privados, sendo moldado de forma a justificá-los. Tem-se, portanto, a formação de um pensamento marcado por incoerências e que, da mesma forma que o processo de constituição do Estado, refletirá o patrimonialismo e o privilégio de interesses particulares em detrimento dos interesses nacionais e coletivos. Assim, o Liberalismo, que no país, foi usado para justificar a emancipação, a superação da fase colonial, conviveu com a escravidão, com o autoritarismo, com a desigualdade, etc. Dessa forma,

"O que importa acentuar é que esse Liberalismo não pôde, em nenhum momento, compatibilizar-se com o Estado brasileiro. Os liberais têm, com o poder, uma relação tempestuosa e ambígua: serão potencialmente ou realmente sediciosos, ou, sem tocar no Estado, farão a política conservadora. Esta cisão está na base do pensamento político brasileiro e terá consequências que impedem o desenvolvimento, a adequação do pensar e o fazer. Melhor: de incorporar ao fazer 0 pensar.

\footnotetext{
${ }^{23}$ FAORO, Raymundo. Existe um pensamento político brasileiro?. Estudos avançados.USP, vol.1 no.1, São Paulo Out/Dec. 1987.
} 
O Liberalismo não conseguiu alterar a estrutura do Estado, instituindo um Estado protetor de direitos." (FAORO, 1987, p. 47)

Assim, para Faoro, seria como se o Liberalismo tivesse sido utilizado em benefício das elites políticas para a emancipação e construção de um Estado que privilegiou seus interesses. Sendo, posteriormente, excluído do pensamento e da ação nacional. O que, para ele, estagnou movimento político nacional e impediu o desenvolvimento e a emancipação política e econômica do país, que universalizasse e democratizasse direitos. Em suma,

"A ausência do Liberalismo, que expressava uma dinâmica dentro da realidade social e econômica, estagnou o movimento político, impedindo que, ao se desenvolver, abrigasse a emancipação, como classe da indústria nacional. Seu impacto revelaria uma classe, retirando-a da névoa estamental na qual se enredou. Interrompida ficou, em consequência, a luta do produtor na crise do sistema colonial e do produtor quando a Revolução Industrial penetra no País. $O$ Liberalismo, ao se desenvolver autenticamente, poderia, ao sair da crisálida da consciência possível, ampliar o campo democrático, que lhe é conexo, mas pode ser-lhe antagônico. Por meio da representação nacional - que necessária ao Liberalismo - amplia-se o território democrático, e participativo, conservando, ao superar, o núcleo liberal. Chegar-se-ia a um ponto em que $o$ que fosse democrático pressupusesse o espaço dos direitos e garantias liberais, ampliáveis socialmente.(...) O Estado seria outro, não o monstro patrimonial-estamental-autoritário que está vivo na realidade brasileira." (FAORO, 1987, p. 55)

Discutimos até agora quatro autores fundamentais para qualquer interpretação da realidade brasileira. Os trabalhos de Gilberto Freyre, Sérgio Buarque, Raymundo Faoro e Caio Prado apresentam uma interpretação de conjunto de nossa realidade buscando respostas para transformação do presente. Tais obras apresentam visões distintas da formação do país. Enquanto Freyre atribui à família o eixo central da colonização, Sérgio Buarque destaca o papel do aventureiro, enquanto 
Caio Prado dá maior importância ao seu caráter comercial e Faoro privilegia a questão do Estado. São interpretações distintas, mas que contribuem para melhor compreensão da realidade brasileira.

Mas se já abordamos e atribuímos importância à questão colonial para discutir formação nacional, a questão da independência do país é essencial na tentativa de interpretação de nossa realidade. No vasto debate e na ampla produção historiográfica sobre a independência do Brasil, encontramos elementos importantes que nos permitem pensar 0 processo de construção do Estado e do pensamento brasileiro. São importantes os trabalhos de Emilia Viotti ${ }^{24}$, que procurou mostrar a influência do pensamento liberal no movimento político de 1822. A autora explora a incoerência desse pensamento que criticava o absolutismo e o colonialismo de um lado, pregando o rompimento dos laços coloniais, mas, por outro lado, mantendo a escravidão como elemento unificador da sociedade imperial que se formara com a emancipação política.

Devemos recordar, também, os trabalhos de Fernando Novais ${ }^{25}$, nos quais o autor argumenta que a Independência foi um processo revolucionário que conduziu ao poder uma nova classe, a dos grandes proprietários de escravos, que se constituíram como força política hegemônica no governo imperial. A emancipação política criou a nação, mas uma nação identificada com os interesses escravistas, resultando daí um país que rompeu com a dominação colonial, mas que caminhou para um novo modelo mundial de subordinação. $O$ movimento emancipacionista se apoiou no liberalismo emergente no século XIX, assim como nas transformações em curso na esfera mundial. Entretanto, ao mesmo tempo, manteve os interesses escravistas e criou uma nação independente em relação à metrópole portuguesa, mas dependente economicamente da ordem econômica mundial que se desenhava, tendo a

${ }^{24}$ COSTA, Emilia Viotti da. Da Monarquia a República. São Paulo: Unesp, 1998. Capítulos "Introdução ao Estudo da Emancipação Política do Brasil" e "Liberalismo: teoria e prática".

${ }^{25}$ NOVAIS, Fernando A. As Dimensões da Independência. In: MOTA, Carlos Guilherme. 1822: Dimensões. São Paulo: Editora Perspectiva, 1972. E NOVAIS, Fernando A.; MOTA, Carlos Guilherme. A Independência política do Brasil. São Paulo: Hucitec, 1996. 
Inglaterra como potência hegemônica. Novais procurou mostrar que o processo de independência extinguiu o exclusivo metropolitano e internalizou o excedente econômico, sendo que a escravidão, o poder dos grandes senhores e todos os laços que remetiam ao passado eram reiterações surgidas no bojo do processo de luta política.

Cabe também recordar Maria Odila da Silva Dias ${ }^{26}$ que, em seu trabalho clássico, procura retomar a visão propagada por Sérgio Buarque $^{27}$ ao afirmar que a independência foi um processo conservador. A autora acredita que a independência não ocorreu simultaneamente à consolidação da unidade nacional, que, a seu ver, só se daria em meados do século. Assim, a emancipação política continha uma continuidade conservadora ao constituir um Estado que reafirmava os laços com o passado colonial e com a metrópole. Desta forma, a metrópole se via interiorizada no país independente. Ao mesmo tempo em que se constituía como país soberano, a interiorização da metrópole, para Maria Odila, dava continuidade ao passado colonial, do qual o país só se separou com a queda de Dom Pedro I e o fim do $1^{\circ}$ reinado, em 1831.

Para Wilma Peres $\operatorname{Costa}^{28}$, é na herança colonial e na forma de sua desagregação que se encontram os principais impulsos centrífugos e centrípetos da construção do Estado na América Latina, portanto, para compreender tal processo é preciso analisar o processo de Independência. Como ressaltado anteriormente, o processo brasileiro teve uma trajetória social conservadora, mantendo e reiterando traços principais do seu passado colonial, as quais, a grande propriedade agrária exportadora e o trabalho escravo.

26 DIAS, Maria Odila da Silva. A interiorização da metrópole (1808-1853). In: MOTA, Carlos Guilherme. 1822: Dimensões. São Paulo: Editora Perspectiva, 1972.

27 HOLANDA, Sérgio Buarque de. A Herança colonial - sua desagregação. In: História Geral da Civilização Brasileira - O Brasil Monárquico: o Processo de Emancipação. Tomo II, $1^{\circ}$ Volume, São Paulo - Rio de Janeiro: DIFEL, 1976.

${ }_{28}$ COSTA, Wilma Peres. A Espada de Dâmocles, o Exército, a Guerra do Paraguai e a crise do Império. SP/Campinas, Ed. Unicamp, Hucitec, 1996. cap. 1. e COSTA, Wilma Peres. O processo de construção do Estado no Brasil (1808-1850) In: SZMRECSÁNYI, Tamás; LAPA, José Roberto do AmaraL(orgs.). História Econômica da Independência e do Império. São Paulo: Hucitec/ABPHE/Edusp/Imprensa Oficial, 2002. 
A autora argumenta que a formação do Estado no Brasil se fez reafirmando e garantindo a escravidão. Assim, por um lado, favoreceu a unidade territorial, a monarquia e a centralização. Por outro lado, no entanto, representou um limite ao Estado, já que, instaurado a partir de uma ordem fundada na violência privada, resistiu ao desarmamento e ao monopólio da violência pelo poder central.

Dos trabalhos que trataram da construção do Estado Imperial no Brasil, certamente um dos mais relevantes é o de José Murilo de Carvalho ${ }^{29}$. Seu estudo procura mostrar a formação das elites que conduziram o processo de emancipação política e construção do Estado Nacional. Para o autor, a unidade territorial na qual se formou o Império do Brasil foi obra de uma elite intelectual que foi capaz de abafar os movimentos centrífugos comandados por forças regionais. Para ele, a construção do Estado apoiava-se em um "processo de acumulação primitiva do poder" ocorrido entre 1837 e 1850. A vitória da elite imperial significou, para ele, a derrota das elites regionais que, submetidas e subordinadas a um poder central, ficavam isoladas em suas províncias.

"Do processo de geração mútua entre Estado e elite resultaram, segundo minha visão, alguns traços marcantes do sistema político imperial, como sejam a monarquia, a unidade, a centralização, a baixa representatividade. A elite produzida deliberadamente pelo Estado foi eficiente na tarefa de fortalecê-lo, sobretudo em sua capacidade de controle da sociedade. Ela foi eficiente em atingir o objetivo da construção da ordem, o objetivo que, parafraseando Marx, chamei de acumulação primitiva do poder." (CARVALHO, 1996, p.229).

Não menos importante é o trabalho de Ilmar Mattos ${ }^{30}$. Assim como José Murilo de Carvalho, o trabalho do autor pensa o Estado Imperial como construção através da ação de uma classe senhorial que se articulou

\footnotetext{
${ }^{29}$ CARVALHO, José Murilo de. A Construção da Ordem: a elite política imperial e Teatro das Sombras: a política imperial. 2.ed. ver. Rio de Janeiro: Editora UFRJ, RelumeDumará, 1996.

30 MATTOS, Ilmar Rohloff de. O tempo saquarema. A formação do Estado imperial. Rio de Janeiro: ACCESS, 1994.
} 
em torno do centro político do Império. Para ele, o processo de construção do Estado e de constituição da classe senhorial são processos interdependentes. A elite saquarema, que dominou o Partido Conservador do Rio de Janeiro, constituiu um projeto nacional, capaz de consolidar uma hegemonia política e de construir o Estado, impondo-se sobre as elites regionais, que detinham projetos descentralizadores e locais. Os saquaremas, portanto, cresceram e se consolidaram, confundindo-se com a própria consolidação do Império. E conseguiram fazê-lo, de modo progressivo. $\mathrm{O}$ autor conclui que,

"Para os Saquaremas a manutenção de uma Ordem e a difusão de uma Civilização apareciam como objetivos fundamentais; eram também os meios pelos quais empreendiam a construção de um Estado e constituição de uma classe. Por sua vez, e de modo necessariamente complementar, a construção do Estado imperial e a constituição da classe senhorial, enquanto processos intimamente relacionados, tornavam-se não apenas resultados de uma intenção traduzida em ação, mas também os requisitos que asseguravam a Ordem e difundiam a Civilização." (MATTOS, 1994, p.267).

Pode-se dizer, a partir disso, que, do processo de construção do Estado no Brasil, consolidou-se a hegemonia de uma classe dominante, na visão de Ilmar Mattos, os saquaremas. Elite política que, alicerçada na escravidão, centralizou o poder e conduziu o governo imperial de forma a garantir os seus interesses, os interesses dos proprietários escravistas, que eram a sua base de constituição e apoio.

Já em Bases do Autoritarismo Brasileiro e, em O Minotauro Imperial, Simon Schwartzman e Fernando Uricoechea ${ }^{31}$ retomam a discussão do patrimonialismo no processo de construção nacional; eles acreditam que este é um traço fundamental da sociedade tradicional e que tenderia a desaparecer com a modernidade. O trabalho de Uricoechea, por exemplo,

\footnotetext{
${ }^{31}$ URICOECHEA, Fernando. O minotauro imperial: a burocratização do Estado patrimonial brasileiro no século XIX. Rio de Janeiro: Difel, 1978. E SCHWARTZMAN, Simon. As bases autoritárias do Estado brasileiro. Rio de Janeiro: Campus, 1988.
} 
apresenta a Guarda Nacional e como essa instituição desaparece com a profissionalização das forças armadas.

Com forte inspiração Weberiana, Uricoechea aponta para as incoerências e contradições do Império Brasileiro a partir da grande presença do poder privado e da grande centralização administrativa e burocrática do poder central. Nesse sentido, a Guarda Nacional teve um papel essencial, por ser tanto privada quanto pública, por ser a ligação entre o poder local e o poder público, entre o moderno e o arcaico, entre a sociedade e o Estado.

O Estado que emerge desta construção, cooptou as elites locais e consolidou uma ordem pública que transcendeu a sociedade patriarcal da qual emergiu. Para o autor, tal processo representou o enfraquecimento do poder privado e o fortalecimento do poder centralizado. Nesse sentido, sempre predominou no país lideranças políticas que se preocupassem em intermediar os interesses, refletindo assim a fraqueza e atonia dos interessados.

Já para Schwartzman, a formação social do Estado no Brasil é marcada pela condução da "coisa pública", a partir de grande centralização política com forte presença do seu caráter patrimonial. O caráter autoritário assumido pelo Estado em diversos momentos sempre representou diminuta participação política da sociedade e contribuiu decisivamente para a consolidação e afirmação dos interesses da classe dominante.

Já Richard Morse procura retomar alguns dos passos de Sérgio Buarque em Raízes do Brasil ao propor, em seu O Espelho de Próspero, a inversão do espelho que o norte apresenta ao sul, através da busca das raízes de civilizações que se constituíram de maneira diversa e original.

Para Morse, há uma contraposição entre a modernidade inglesa e a ibérica que se refletem na formação anglo-americana e ibero-americana. A adaptação ao pensamento liberal, a libertação às tradições religiosas são marcas importante da formação da Inglaterra. Não por menos, assume papel decisivo no desenvolvimento econômico e na consolidação 
da democracia na América do Norte após a independência das trezes colônias.

De forma distinta, a América Latina incorpora toda a tradição ibérica, que, ligada a uma tradição culturalmente rica e consolidada, foi menos afeita às transformações promovidas e propostas pelas revoluções religiosas e científicas e, desta forma, buscou acomodar e promover uma ordem cultural mais universal. Assim, após seus processos de independência, a sociedade latina sempre teve dificuldades de compreender e se adaptar ao liberalismo e à democracia, criações que, em diversos momentos, Ihe parecem estranhas.

Assim, para Morse, é preciso negar o espelho e o modelo de civilização que nos parece imposto e que nos é estranho diante de nossas raízes culturais. Por outro lado, e tentando retomar o nosso argumento, é preciso refletir acerca de todo o processo de construção da sociedade latino-americana. No campo das ideias e, especificamente, no Brasil, parece cada vez mais claro que o pensamento liberal sempre teve um caráter próprio e peculiar, resultado desta aporia cultural, sempre colocada através de modelos e padrões a serem seguidos e copiados de um centro que assume seu papel de centro por uma periferia que assume seu papel de periferia.

O trabalho de Morse suscitou muitas polêmicas por apresentar uma interpretação que, em vez de negar o passado ibérico, nega o modelo de civilização baseado na lógica europeia e americana. O principal debate a respeito do tema se deu entre o próprio Morse e Simon Schwartzman, em uma série artigos na Revista Novos Estudos CEBRAP. ${ }^{32}$

Este debate, de certa forma, polariza também uma polêmica comum nas reflexões sobre o Brasil desde o século XIX, como nos alerta Luiz

\footnotetext{
32 O debate se inicia com o comentário (resenha) que Schwartzman faz do livro de Morse e é seguido por uma resposta de Morse e por uma réplica de Schwartzman. Ver SCHWARTZMAN, Simon. O Espelho de Morse. Novos Estudos CEBRAP, 22, Outubro, 1988; MORSE, Richard. A Miopia de Schwartzman. Novos Estudos CEBRAP, 24, julho, 1989; SCHWARTZMAN, Simon. O gato de Cortázar. Novos Estudos CEBRAP, 25, outubro, 1989.
} 
Werneck Vianna ${ }^{33}$, ou seja, o debate entre americanistas e iberistas. Enquanto americanistas veem na herança ibérica a raiz do atraso e o elemento a ser superado pela modernização, iberistas acreditam que tal herança seria a matriz de um outro tipo de modernização menos individualista e que por isso deveria ser valorizada na busca pelo desenvolvimento e reafirmação da cultura e identidade nacional. Lucia Lippi de Oliveira ${ }^{34}$ sintetiza bem a questão,

"Para muitos intelectuais e pensadores, o atraso é consequência da persistência histórica do mundo ibérico, incapaz de possibilitar a criação dos fundamentos da razão moderna. A herança ibérica seria assim uma espécie de determinação estrutural, a matriz de uma gramática, que regularia a marcha da história. Frente à esta matriz é possível identificar duas posições: a dos "americanistas", que identificam na herança ibérica o obscurantismo, o autoritarismo e o burocratismo presentes na vida política e social do Brasil; e a dos "iberistas", para quem esta matriz, ao contrário, foi capaz de preservar uma ética moderna, não individualista e comunitária." (OLIVEIRA, 2000, p. 47)

Na visão "iberista" de Morse, o modelo civilizatório anglo-saxão, baseado no liberalismo e no indivíduo racional e maximizador, não é garantia de sucesso para uma sociedade. Pelo contrário, na visão do autor, tal modelo estaria em crise e ao contrário do que se poderia supor, a América Ibérica seria uma alternativa à crise da sociedade individualista e racional norte-americana e não o contrário. Enquanto contemplamos e buscamos na América Anglo-Saxônica a solução para nossos dilemas, não conseguiríamos perceber que ela está em crise, não fornece resposta e que a chave para os problemas justamente seria a valorização de nossa própria cultura.

Já para Schwartzman, em uma visão que poderia ser considerada "americanista", não se trata de opor duas culturas. O autor aponta que a

33 WERNECK VIANNA, Luiz. A revolução passiva: iberismo e americanismo no Brasil. Rio de Janeiro: Revan, 1997.

${ }^{34}$ OLIVEIRA, Lúcia Lippi. Americanos: representação da identidade nacional no Brasil e nos EUA. Belo Horizonte: Ed. UFMG, 2000. 
herança ibérica foi decisiva na construção do Estado no país, constituindose a partir de estruturas burocrático-patrimonialistas que impediram a modernização política e a racionalização das instituições. Nesse sentido, a chave para a solução dos dilemas nacionais é mais política que cultural.

Criticando Morse, o autor acredita que a visão de que os dilemas da América Latina se resolveriam a partir da valorização da cultura nacional e da rejeição à cultura "importada" é sedutora, uma vez que,

"É fácil deixar-se fascinar pela inteligência, erudição, elegância e agudeza deste livro, fruto de um trabalho de scholarship dificilmente encontrável fora dos circuitos acadêmicos do Norte. É difícil também não deixar-se seduzir pela mensagem que nos transmite este espelho, que confirma aquilo que sempre pensamos, ou ansiamos, no recôndito de nossas almas: apesar de nossa pobreza, de nossas tragédias, de nossos horizontes truncados, e da riqueza e segurança de si que 'eles' exibem todo o tempo, nós somos superiores, temos o segredo da vida e do futuro. Agora, finalmente, eles reconhecem. Não importa que toda a evidência empírica, toda a vivência do dia a dia, sugiram o contrário; que é o empírico, afinal, senão o aspecto mais superficial da realidade, 'um mosquito' que pode até nos ser inacessível e nos importunar, mas que é indigno do 'rolo compressor' de nossa atenção."

"E, no entanto, é preciso não cair na tentação deste jogo de espelhos traiçoeiro, e dizer, com todas as letras, de que se trata de um livro profundamente equivocado e potencialmente danoso em suas implicações. Não é uma tarefa fácil, para quem não dispõe da erudição e da facilidade expressiva de Morse. Mas não é uma tarefa impossível, e acredito que deve ser tentada". (SCHWARTZMAN, 1988, p.186)

Evidentemente que a ironia é uma peça importante da retórica utilizada pelos autores durante o debate. $O$ início do trabalho de Schwartzman expõe com sarcasmo que o trabalho de Morse nos diz ser inútil a imitação e que "o liberalismo, a democracia representativa, o racionalismo, o empirismo científico, o pragmatismo" seriam meros ideais alardeados por nosso "irmãos ricos", mas que não se enquadrariam e não serviriam a nossa realidade cultural, menos presa a mesquinharia e a 
valorização das pequenas coisas dado nosso apego a essência espiritual dos homens.

Outro ponto que incomoda o autor em $O$ espelho de Próspero seria uma suposta desvalorização do cientificismo e de acadêmicos latino americanos que seriam meros copiadores das Universidades do norte e que, assim, "a poetas, romancistas e artistas restaria a tarefa de expressar seu mundo 'como centro e não como periferia' ".

O debate continua com uma resposta também intensamente irônica de Morse a Schwartzman, em que o autor começa ironicamente elencando pontos em comum com o seu crítico, como o gosto pela racionalidade, pelos direitos humanos e pela ciência humanística em contraste à opressão, o misticismo e niilismo intelectual. Contudo, aponta uma série de discordâncias.

Para ele, "seu crítico", como a ele se refere ao longo do texto, tem uma visão linear da história e uma confiança grande na capacidade de acadêmicos e cientistas de prever o futuro e de serem os heróis da transformação da sociedade. Morse reafirma suas críticas à academia e à necessidade de revalorização das culturas nacionais Latino-Americanas expressas, sobretudo na obra de escritores como Guimarães Rosa, Borges, Garcia Márquez, Cortázar, entre outros. Trata-se, portanto, de valorizar as raízes da cultura nacional. Em grande medida, a crítica de Morse não é relacionada à incapacidade intelectual dos acadêmicos LatinoAmericanos, mas à incapacidade de criar algo próprio, de teorizar a agir a partir das especificidades nacionais. $O$ autor valoriza os acadêmicos das primeiras gerações da formação da Universidade no Brasil, por exemplo na USP, entre os anos 40 e 60. Mas lamenta que a Universidade brasileira tenha perdido o sentido inicial, ou seja, de busca pela cultura nacional e sua reafirmação.

A réplica de Schwartzman retoma a tendência irônica e sarcástica dos textos anteriores logo em seu título, O gato de Cortázar, eu referência 
ao celebre escritor argentino e a um de seus mais conhecidos $\operatorname{contos}^{35}$. No texto procura refutar a ideia que, segundo ele, Morse tentou passar de sua visão como reacionário, empirista primitivo, racionalista ingênuo, defensor do status quo acadêmico. Para tanto, retoma os seus argumentos e conclui pela necessidade da América Latina superar os seus dilemas através da modernização de suas instituições, principalmente, educacionais, políticas, culturais e científicas, reafirmando o papel central do trabalho acadêmico-científico sistemático e de longo prazo.

Trata-se, portanto, de um debate importante, que expõe visões essenciais e que, de certa forma, nos permite conectar toda a discussão que tentamos apresentar neste trabalho. Devemos, entretanto, lembrar que tal debate necessita ser contextualizado. O livro de Morse foi publicado no Brasil em 1988 e o debate acima citado se desenvolveu entre 1988 e 1989. O momento histórico é importante por vários aspectos. No campo político, o neoliberalismo e a crítica ao Estado interventor e de bem estar social começam a se desenhar na cabeça de certa parte da intelectualidade brasileira, bem como, em escala internacional, o socialismo soviético, que se encontrava em crise. No campo das ciências sociais, novos temas de investigação e pesquisa começam a tomar conta da agenda de pesquisadores e intelectuais. No campo da história, novos temas e novas abordagens, ou se quisermos usar o termo de Dosse, a "história em migalhas". As ciências sociais encontravam-se em plena transformação, sai-se das grandes questões das décadas de 1940, 1950 e 1960 para os micro temas, da história totalizante para a Micro-História. Mudam-se as perguntas, mudam-se os temas, mudam-se as abordagens. É dentro desta perspectiva que devemos analisar este debate. A visão de Morse mostrou-se polêmica porque se opôs à visão americanista, de reforma do Estado, da política, da economia, da cultura, etc, que começava a se impor naquele momento.

No que nos interessa, aqui, cabe tentar entender tal debate dentro da perspectiva da formação das ideias, no Brasil. Todos os trabalhos até

\footnotetext{
${ }^{35}$ Ver o conto "Orientação dos Gatos" de Julio Cortázar.
} 
agora discutidos, uns de uma forma, outros de outra, tentaram entender como a herança do passado colonial influenciou a nossa formação e o que somos hoje. Cabe a nós tentar compreender como essa questão se relaciona com a formação do pensamento brasileiro.

Em texto anteriormente citado, Faoro questiona a existência de um pensamento político brasileiro. Tal questão poderia estender-se a outros campos das ciências sociais; existe um pensamento econômico brasileiro, existe um pensamento filosófico brasileiro ${ }^{36}$

Faoro aponta para uma questão essencial e, ao analisar o liberalismo, argumenta que sempre esteve vinculado à prática política no país e não ao pensamento político. Em parte, na visão do autor, uma das limitações ao pensamento político brasileiro seria a necessidade de se ter um quadro cultural autônomo, que permitisse a sociedade produzir a suas próprias ideias.

Notamos, portanto, que a discussão a respeito do pensamento político brasileiro gira muito entorno da apropriação da noção de liberalismo no país, principalmente no século XIX, a partir da Independência. Alguns trabalhos importantes, além do de Faoro, buscaram compreender a questão ${ }^{37}$.

Wanderlei Guilherme dos Santos aponta que o liberalismo foi adaptado a realidade social brasileira desde o século XIX. Durante o Império, na visão do autor, o ideário liberal povoou a cabeça de conservadores e liberais de maneira distinta. Conservadores acreditavam que seria possível, a partir das ideias liberais, transformar as estruturas e manter a realidade social. Enquanto liberais acreditavam que o liberalismo e adoção de suas intuições, vigentes nas sociedades dos EUA e Europa,

\footnotetext{
${ }^{36}$ Este tipo de problemática aparece também quando se discute a questão da literatura nacional. Ver CANDIDO, Antonio. Literatura e Sociedade. $8^{a}$ edição, São Paulo: Publifolha, 2000.

${ }^{37}$ Ver FAORO, Raimundo. Existe um pensamento político brasileiro?. Op. Cit.; SANTOS, Wanderley Guilherme dos. Ordem burguesa e liberalismo político. São Paulo: Livraria Duas Cidades, 1978; SCHWARZ, Roberto. Ao vencedor as batatas. São Paulo: Ed. 34, 2000. Cap. "As ideias fora do lugar".
} 
seriam suficientes para transformar a sociedade brasileira em algo similar a estas.

Para Roberto Schwartz havia uma inadequação das ideias liberais à realidade social brasileira. A escravidão fez com que o liberalismo tivesse um conteúdo bastante específico no país, atendendo a interesses particulares e não à sua finalidade universal. Tal interpretação gerou uma série de debates que se pode vincular aos debates a respeito da Teoria da Dependência. Não é o caso aqui de explorar mais a fundo tal questão ${ }^{38}$.

O fato é que, de uma forma ou de outra, há uma dificuldade de se compreender o pensamento estritamente nacional por algumas razões. Se o pensamento político brasileiro se estruturou a partir do liberalismo, a herança colonial ou a herança ibérica impõe diversas questões à nossa interpretação.

Se a herança ibérica nos impõe um outro tipo de matriz civilizatória, ou de cultura, avessa aos ideais individualistas e maximizadores do mundo moderno, nos quais o liberalismo se apoia, o pensamento político, econômico e social brasileiro, ao se apropriar do ideário liberal, somente poderia produzir algo adaptado, enquadrado à realidade brasileira diferente. Nasce daí o primeiro problema, seria, esse pensamento, original? A adaptação de ideias produzidas fora da Brasil poderia caracterizar originalidade?

Por outro lado, se a herança colonial e ibérica são um fardo a ser superado e tal superação viria pela adoção dos princípios modernizadores que tomam conta do primeiro, nosso pensamento político, econômico e social seria mera cópia do que se produz ou produziu lá fora?

No que tange ao pensamento econômico, acreditamos que existem lacunas e diversas possibilidades de pesquisa. Entender o pensamento econômico brasileiro e suas possibilidades é tarefa para os próximos capítulos.

\footnotetext{
${ }^{38}$ Para tanto ver o trabalho de FRANCO, Maria Sylvia de Carvalho. As ideias estão em seu lugar. Cadernos de Debate, 1976.
} 
A questão metodológica é um aspecto fundamental a todos os trabalhos que pretendem abordar a História do Pensamento Econômico Brasileiro. A questão sobre o que é e como expor o pensamento econômico brasileiro não é trivial e por isso sua discussão é difícil. São poucas as obras a respeito do tema e nem sempre estas obras se preocupam em responder tais questões.

Os dois trabalhos clássicos a respeito do pensamento econômico brasileiro apresentam discussões limitadas a respeito da questão metodológica. Além disso, limitam ao século XX o ponto de partida das análises. ${ }^{39}$

Algumas questões nos parecem essenciais. Primeiro, para discutir o pensamento econômico brasileiro é fundamental defini-lo e tal definição passa, sobretudo, por uma discussão a respeito das possibilidades da existência de um pensamento econômico nacional. Além disso, definida e delimitada a questão, nos cabe entender porque grande parte dos trabalhos sobre o tema se limitam ao século $X X$, ignorando assim o século XIX.

Contudo, será que não seria importante tentar entender como caminharam as ideias econômicas no Brasil durante o século XIX?

Não há como ignorar o caso do pensamento político brasileiro. Toda discussão se origina a partir da formação e consolidação da nação no século XIX, partindo da discussão de como tais ideias se apropriam do liberalismo, bem como têm uma influência decisiva de nossa herança ibérica e colonial. Por que não analisar o pensamento econômico sob perspectiva semelhante? Nos parece claro que, assim como a questão política, o aspecto econômico sempre ocupou um papel central na formação e na evolução do país.

Nos capítulos que se seguem, procuramos definir o que seria 0 pensamento econômico brasileiro, bem como apresentar a sua possibilidade de consideração durante o século XIX.

39 BIELSCHOWSKY, Ricardo. Pensamento Econômico Brasileiro: o ciclo ideológico do desenvolvimentismo. Rio de Janeiro: Contraponto, 2004; MANTEGA, Guido. A economia política brasileira. São Paulo/Petrópolis: Vozes, 1985. 


\section{Capítulo 2}

\section{O Pensamento Econômico Brasileiro: perspectivas interpretativas}

Uma das grandes dificuldades do historiador é delimitar seu objeto de estudo, bem como estabelecer uma periodização para sua análise. Diante desta dificuldade, o pesquisador faz escolhas, que, quase sempre, evidenciam opções teóricas e determinam os rumos do seu trabalho. $O$ desafio se coloca quando nos propomos a abordar o Pensamento Econômico Brasileiro. Trata-se, antes de tudo, de uma discussão metodológica.

Todo trabalho de História do Pensamento Econômico parte de uma escolha, ou seja, depende, essencialmente, de uma seleção de quais autores ou pensadores serão abordados, portanto, de uma opção metodológica, que reflete posições teóricas. Assim, há um sentido em estudar um determinado grupo de pensadores em detrimento de outros.

Isso pode, aparentemente, fazer pouco sentido. Afinal, é mais ou menos consensual o conteúdo de obras e disciplinas de História do Pensamento Econômico. Geralmente, relacionamos a questão à evolução das ideias econômicas desde os seus primórdios, com Adam Smith até as evoluções neoclássicas e keynesianas do século $\mathrm{XX}$, passando pela crítica marxista da economia política clássica. Contudo, até mesmo esse consenso reflete uma opção, ou, dito de outra forma, reflete como tendemos a associar História do Pensamento Econômico à evolução do capitalismo.

Mas isso não encerra a questão. Por trás das opções metodológicas, além de um consenso, existem posições teóricas divergentes, visões de mundo que se contrapõem. A História do Pensamento Econômico, assim sendo, não é neutra e a maneira como a enxergamos diz muito da nossa realidade e da forma como refletimos sobre a Economia e o mundo que nos cerca.

Refletir a respeito do Pensamento Econômico Brasileiro, bem como sobre sua história, implica, inevitavelmente, na discussão a respeito da 
possibilidade de reconstituição histórica de pensamentos econômicos nacionais, contemplando aspectos geográficos, históricos e sociais. Tal discussão envolve a afirmação do pluralismo metodológico, bem como uma crítica à pretensa universalidade da teoria econômica. Ao longo deste capítulo abordamos tal questão a partir de três aspectos específicos.

Primeiro, a partir da possibilidade da existência de um pensamento econômico nacional. Tal discussão remete, essencialmente, à distinção levantada por Schumpeter entre análise econômica e pensamento econômico e seus desdobramentos. Esta questão está relacionada à suposição de que o conhecimento econômico, a análise econômica ou a teoria econômica teriam caráter universal. Assim, haveria apenas a ou uma história do pensamento econômico, aquela que abordaria a evolução das ideias econômicas desde a sua emergência até o período contemporâneo. A partir desta perspectiva, qualquer especificidade teórica relacionada a problemas nacionais ou regionais específicos seriam ignoradas, assim como qualquer possibilidade de admitir qualquer diversidade teórica na economia.

Evidentemente discordamos desta proposição. A Economia, como uma ciência social, está sujeita a diferentes abordagens metodológicas e teóricas, bem como suas perspectivas de reflexão estão condicionadas por fatores históricos e regionais. Ou seja, a natureza e o tipo de reflexão econômica têm sim relação com espaços nacionais específicos e não só podem, como devem, ser abordados a partir da perspectiva nacional. Como bem lembram Almodóvar \& Cardoso $^{40}$, reconhecer as possibilidades de histórias do pensamento econômico nacionais é não só reforçar o pluralismo metodológico na economia, bem como reconhecer que a teoria e as reflexões econômicas são resultados das diversas formações históricas e culturais. Assim, o segundo aspecto que pretendemos abordar nas páginas que seguem é como definir um pensamento econômico nacional.

\footnotetext{
${ }^{40}$ ALMOdOVAR, António; CARDOSO, José Luís. A History of Portuguese Economic Thought. Londres: Routledge, 1998.
} 
Por fim cabe definir o que seria o Pensamento Econômico Brasileiro. Tal questão remete ainda à pouca atenção dada ao século XIX nos trabalhos e discussões a respeito do tema. Os trabalhos clássicos de Ricardo Bielschowsky e Guido Mantega ${ }^{41}$, por exemplo, concentram toda a atenção no século $X X$, considerando apenas como Pensamento Econômico Brasileiro o debate intelectual e reflexivo em torno das questões pertinentes ao desenvolvimento econômico e a superação do subdesenvolvimento no país.

A partir desta discussão, e levando em consideração a possibilidade, bem como a definição do que é o Pensamento Econômico Brasileiro, pretendemos apontar para a existência de um Pensamento Econômico Brasileiro no século XIX e a sua importância para a melhor compreensão da formação histórica e econômica nacional.

$$
===
$$

O importante trabalho de Joseph Schumpeter ${ }^{42}$, História da análise econômica, levanta alguns pontos importantes. Logo no início do livro, discutindo a questão do método, o autor, ao buscar justificar o estudo de história, argumenta que "a matéria econômica é um processo histórico único, de modo que, a largo alcance, a economia de diferentes épocas trata de diferentes conjuntos de fatos e problemas". Portanto, a história das doutrinas econômicas seria de grande interesse. Entretanto, para ele, "a economia científica não carece de continuidade histórica" e seu objetivo principal com a obra seria descrever "o processo pelo qual o esforço dos homens para compreender o fenômeno econômico produz, aperfeiçoa e destrói as estruturas analíticas numa sucessão interminável" (SCHUMPETER, 1964, p.26). Esta seria a sua tese ao longo do livro, mostrar que a economia não difere de outros campos do conhecimento. Ou seja, a teoria econômica (que importa) seria uma sucessão de

\footnotetext{
${ }^{41}$ BIELSCHOWSKY, Ricardo. Pensamento Econômico Brasileiro: o ciclo ideológico do desenvolvimentismo. Rio de Janeiro: Contraponto, 2004; MANTEGA, Guido. A economia política brasileira. São Paulo/Petrópolis: Vozes, 1985.

42 SCHUMPETER, Joseph. História da Análise Econômica. $1^{\circ}$ Volume, Rio de Janeiro:

Fundo de Cultura, 1964.
} 
análises, específicas de seu tempo, carregadas de verdades científicas, que ao longo do tempo se aperfeiçoam em busca da verdade absoluta.

Schumpeter descreve também, já no segundo capítulo, o que seriam as técnicas da análise econômica. Nesta parte, começa a diferenciar a análise econômica dos sistemas de economia política, bem como do pensamento econômico. É no quarto capítulo que o autor irá esclarecer essencialmente $\mathrm{o}$ objetivo e a metodologia de seu trabalho. Para Schumpeter, a Análise Econômica é a economia em si, que junta História, Sociologia, teoria e Estatística para explicar a realidade, portanto, Economia Aplicada. Já os Sistemas de Economia Política estariam ligados a questões ideológicas e políticas, enquanto o Pensamento Econômico estaria ligado à prática, ou, por assim dizer, à ideia de política econômica. Assim, a História da Análise Econômica seria diferente da História dos Sistemas de Economia Política e da História do Pensamento Econômico.

Logo, para ele, pensamento econômico estaria ligado "à exposição de um amplo conjunto de políticas econômicas que seu autor sustenta tendo por fundamento determinados princípios unificadores (normativos), como princípios do liberalismo econômico, do socialismo, etc." ou "a soma total de todas as opiniões e desejos referentes a assuntos econômicos, especialmente relativos à política governamental que, em determinado tempo e lugar, pertencem ao espírito público. Daí surge a diferença essencial, porque a análise econômica não estaria interessada no que determinado autor "defendeu, mas, sim, em como defendeu e quais instrumentos de análise usados para isto." (SCHUMPETER, 1964, p.65)

A perspectiva lançada por Schumpeter teve importantes desdobramentos para a História do Pensamento Econômico. Vejamos, por exemplo, o respeitado Mark Blaug ${ }^{43}$. Inicialmente, o autor nos apresenta a História do Pensamento Econômico como um estudo crítico das teorias do

\footnotetext{
${ }^{43}$ Ver, BLAUG, Mark. On the Historiography of Economics. Journal of the History of Economic Thought, 12, 1990; BLAUG, Mark. No History of Ideas, Please, We're Economists. The Journal of Economic Perspectives, Vol. 15, No. 1, 2001; BLAUG, Mark. Economic theory in retrospect. 3. ed. Cambridge; London: Cambridge University, 1983.
} 
passado, onde a crítica tem, inevitavelmente, como referência, a teoria moderna e contemporânea.

"This is a critical study of theories of the past: it concentrates on the theoretical analysis of leading economists, neglecting their lives, their own intellectual development, their precursors, and their propagators. Criticism implies standards of judgment, and my standards are those of modern economic theory. This would hardly be worth saying were it not for the fact that some writers on the history of economic thought have held out the prospect of judging past theory in its own terms. Literally speaking, this is an impossible accomplishment for it implies that we can erase from our minds knowledge of modern economics". (BLAUG, 1983 , p. 1)

Assim, apresenta uma visão a partir de uma perspectiva voltada para a questão do avanço, aperfeiçoamento das ideias. E, portanto, a teoria econômica e o pensamento econômico seriam encarados sob a perspectiva da constante evolução e aperfeiçoamento dos instrumentos analíticos.

"No idea or theory in economics, physics, chemistry, biology, philosophy and even mathematics is ever thoroughly understood except as the end-product of a slice of history, the result of some previous intellectual development. (...) Economic knowledge is pathdependent. What we now know about the economic system is not something we have just discovered, but it is the sum of all discoveries, insights and false starts in the past." (BLAUG, 2001, p.156)

Dessa forma, a História do Pensamento Econômico deveria partir de uma reconstrução do passado de modo racional, pois só assim se poderia chegar à verdade do que determinados autores pensavam. Aparentemente o autor procura fugir do anacronismo, contudo, o que o guia é uma preocupação do presente, portanto, sua análise tem um propósito teórico, qual seja, o avanço, o progresso na teoria econômica.

"I have come to the conclusion that the only approach to the history of economic thought that respects the unique nature of the subject material, rather than just turning it into grist for the use of modern analytical 
techniques, is to labor at historical reconstructions, however difficult they are. Rational reconstruction makes past thinkers appear to be a bit more like us than they were; historical reconstructions make them out to be a little less like us than they were. (...) There is progress in history of economic thought just as there is in economics as a whole: to read even such great scholars of yesterday as Jacob Hollander and Jacob Viner on Adam Smith is to realize how far we have come in Smithian studies in recent decades. (...) historical reconstructions, which involve accounting for the ideas of past thinkers in terms that these thinkers and their contemporary followers would have accepted as a correct description of what they intended to say, are very difficult to carry out. They require careful reading not only of the texts of the economists that one is studying, but also of the previous generation of thinkers in order to understand the context in which the economists in question were writing. Historical reconstructions require us to travel backwards in time, to drive the intellectual vehicle of economics by looking in the rearview mirror." (BLAUG, 2001, p.150-151)

Nesta perspectiva apresentada por Blaug, os autores ou pensadores econômicos são apreendidos e analisados independentemente dos aspectos históricos ou sociais em que estão envolvidos e suas proposições avaliadas de acordo com os desdobramentos contemporâneos da teoria econômica.

O autor também coloca a questão a partir de outra perspectiva, de forma semelhante à visão de Schumpeter ao apresentar a distinção entre absolutismo e relativismo na construção da História do Pensamento Econômico. A posição relativista, levando em consideração o contexto histórico e social, avaliaria a teoria econômica e seus pensadores a partir da sua capacidade de responder aos problemas específicos de seu tempo, tendo pouco importância a sua contribuição para a evolução da teoria econômica moderna. Por outro lado, a posição absolutista avaliaria as formulações teóricas e seus pensadores em sua capacidade de contribuir com o avanço da teoria econômica contemporânea, independentemente de sua relação com o contexto histórico e social. 
"The relativist regards every single theory put forward in the past as a more or less faithful reflection of contemporary conditions, each theory being in principle equally justified in its own context; the absolutist has eyes only for the strictly intellectual development of the subject, regarded as a steady progression from error to truth. Relativists cannot rank the theories of different periods in terms of better or worse; absolutists cannot help but do so. Now, of course, few commentators have ever held either of these positions in such an extreme form, but almost every historian of economic thought can be placed near one or the other pole of what is in fact a continuum of attitudes to the theories of the past. (BLAUG, 1983, p. 2)

Tal abordagem se assemelha à análise econômica schumpeteriana ao apontar a teoria como uma construção autônoma e independente dos fenômenos históricos e sociais. Para Blaug, não haveria uma abordagem mais ou menos adequada e esse julgamento dependeria do historiador e dos objetivos de seu trabalho.

De maneira semelhante ${ }^{44}$, José Luiz Cardoso argumenta que a História do Pensamento Econômico é heterogênea, sendo que as abordagens não seriam excludentes, vendo como legítimo o desejo de uma abordagem que congregue as duas vertentes. Para ele, "as distintas formas de se fazer a História do Pensamento Económico possuem validade e pertinência que não podem ser julgadas por uma arbitragem epistemológica pretensamente neutra" (CARDOSO, 1989, p.18). Caberia ao pesquisador escolher a opção de acordo com a natureza e o objetivo que sua pesquisa pretende cumprir. ${ }^{45}$

\footnotetext{
44 "De forma abreviada, teremos: absolutismo ou reconstrução racional como a visão que privilegia o processo interno de evolução positiva da ciência econômica tomando como referência os avanços teóricos alcançados no tempo presente; e relativismo ou reconstrução histórica como a visão que privilegia as condições e circunstâncias históricas, de tipo social, econômico, institucional ou político, em que emerge e se desenvolvem a ciência econômica". (CARDOSO, 1997, p.216)

${ }^{45}$ Neste sentido, apesar de aceitar a tipologia proposta por Blaug, Cardoso adverte que a abordagem absolutista é uma forma de tratar o problema mas não a única e que sua aceitação irrestrita pode representar, em grande medida, a perda de significado cultural e histórico da história do pensamento econômico. Ver CARDOSO, José Luís. $O$ pensamento econômico em Portugal nos finais do século XVIII (1780-1808). Lisboa: Editorial Estampa, 1989; Cardoso, José Luis. Pensar a Economia em Portugal. Digressões históricas. São Paulo: Difel, 1997; CARDOSO, José Luis. História do Pensamento
} 
Portanto, esta polarização entre análise econômica e pensamento econômico, ou entre abordagem absolutista e abordagem relativista, se apresentam como alternativas metodológicas aos historiadores do pensamento econômico.

Contudo, esta questão metodológica levantada por Schumpeter expõe um problema. Ao tentar diferenciar análise econômica do pensamento econômico, o autor não consegue perceber que não se pode separar uma da outra. Esta separação carrega consigo uma concepção, a nosso ver equivocada, da história, como a história "do que se impôs". Ou seja, a concepção de Schumpeter ignora o fato de que o pensamento econômico é resultado de determinada realidade histórica, assim como a própria Economia, e que não faria sentido separá-las, pois não há só uma Economia, como também não há só um pensamento econômico. A visão de Schumpeter é anacrônica, pois não consegue perceber e entender que a Economia ou a teoria econômica não fazem nem podem fazer sentido se não considerarmos a realidade e o sentido histórico nas quais estão inseridas. Ou seja, não se pode pensar o passado a partir de elementos que só fazem sentido no presente. Logo, fazer uma História da Análise Econômica, tendo como referência o método do equilíbrio geral walrasiano e como os instrumentos e métodos do passado se aproximavam de tal método, ou contribuíram para ele, é incorrer no grave equívoco do anacronismo.

Maurice Dobb, por exemplo, no clássico Teorias do Valor e Distribuição desde Adam Smith, procura se contrapor a Schumpeter. A partir de uma perspectiva marxista, Dobb argumenta que o pensamento econômico é sempre uma resposta aos problemas da sociedade, portanto, a teoria econômica responde a um contexto social e histórico, procurando justificá-lo, ou mesmo, questioná-lo. Assim, há sempre alguma coisa por trás do pensamento econômico, que dá a ele sentido. Nas palavras de Dobb, "Independentemente do que se possa esperar a priori, a História da

Econômico Português. Temas e problemas. Lisboa: Livros Horizonte, 2001; ALMODÓVAR, António; CARDOSO, José Luís. A History of Portuguese Economic Thought. Londres:

Routledge, 1998. 
Economia Política, já a partir de sua origem, revela com abundante clareza o quão próxima (e até mesmo de forma deliberada) a formação da teoria econômica esteve ligada à formação e defesa de políticas econômicas" ${ }^{\prime 46}$.

Assim, para Dobb, nem a Economia nem a História do Pensamento Econômico são neutras, ou seja, toda opção metodológica ou teórica reflete também um posicionamento político, uma visão de mundo. Não há como entender a Economia e o pensamento econômico sem entender a História; uma faz parta da outra. Trata-se, portanto, de entender as ideias econômicas diretamente ligadas e relacionadas ao seu contexto histórico.

O trabalho de Schumpeter reflete uma visão de mundo e uma opção teórica. Uma visão de mundo que crê na necessidade da exatização das ciências sociais, na concepção falsificacionista e positivista da Filosofia da Ciência e na crença da existência de uma verdade econômica única e universal. Uma opção teórica, também, que apontaria a teoria econômica neoclássica e seus princípios fundamentais do equilíbrio geral como o fim da História. Nos termos de Pérsio Arida ${ }^{47}$, seria uma forma de encarar a Economia como uma hard science, quase uma ciência exata, desvalorizando, assim, o conhecimento da História do Pensamento Econômico.

A questão que se coloca é: quais as implicações de se fazer ou não a distinção entre análise econômica e pensamento econômico? Fazê-la implica no reconhecimento de que a Economia é uma ciência metodologicamente próxima das ciências exatas, ainda que se admita a heterogeneidade do pensamento econômico. Significa entender a Economia como um conjunto de conhecimentos que se acumulam e se aperfeiçoam ao longo do tempo, sempre apresentando teorias de fronteira

\footnotetext{
${ }^{46}$ Ver DOBB, Maurice. Teorias do Valor e Distribuição desde Adam Smith. Lisboa: Presença, 1976.

${ }^{47}$ ARIDA, Pérsio. A História do Pensamento Econômico como teoria e retórica. In: RÊGO, J.M.; GALA, P. (orgs.). A História do Pensamento Econômico como teoria e retórica: ensaios sobre metodologia em Economia. São Paulo: Ed. 34, 2003. Também sobre o assunto, ver BIANCHI, Ana Maria. A pré-história da Economia. São Paulo: Hucitec, 1988. (capítulo 1)
} 
que representariam o conhecimento atual e válido. Mas a implicação mais importante é a aceitação de que o saber econômico é universal e de que o saber econômico original não tem nacionalidade. A Economia, como ciência, pensa o mundo abstratamente e, por isso, pouco importa o lugar onde é produzida. Nacionalidade e originalidade são questões que não merecem figurar numa discussão desse tipo.

Contudo, não fazer tal distinção implica em reconhecer a Economia como uma ciência social. Significa entendê-la como resultado de determinações históricas e sociais, e respeitá-la em sua diversidade. Tal diversidade exige histórias do pensamento econômico plurais, tornando relevante a discussão da nacionalidade e originalidade em sua elaboração. A questão da universalidade ou nacionalidade do conhecimento é geral nas ciências humanas, assim como o debate sobre a originalidade desse conhecimento $^{48}$. Reclamar a nacionalidade e a originalidade do conhecimento poderia ser uma atitude menor, mero desejo vaidoso de afirmar uma identidade. Se a Economia é análise econômica, essas questões são realmente menores. Contudo, se não há distinção entre análise econômica e pensamento econômico, nacionalidade e originalidade tornam-se relevantes, porque as determinações sócio-históricas são fundamentais para a formação do pensamento econômico e para a formulação de teorias econômicas. Além disso, estão no cerne de reflexões autônomas sobre a própria realidade, o que é ainda mais dramático nos espaços econômicos periféricos, onde a busca por identidade se apresenta como necessidade histórica para superação de seus problemas específicos. ${ }^{49}$

\footnotetext{
${ }^{48}$ Ver por exemplo CANDIDO, Antônio. Literatura e sociedade. São Paulo: Publifolha, 2000; FAORO, Raymundo. Existe um pensamento político brasileiro?. Estudos avançados, vol.1 no.1 São Paulo Oct./Dec. 1987; ARANTES, Paulo. Providências de um crítico literário na periferia do capitalismo. In: ARANTES, Paulo; ARANTES, Otília. SENTIDO DA FORMAÇÃO. São Paulo: Paz e Terra, 1997.

${ }^{49}$ Ver COSENTINO, Daniel; GAMBI, Thiago; SILVA, Roberto. Adaptação e originalidade na construção de um pensamento econômico nacional. In: XVIII Encontro Nacional de Economia Política, 2013, Belo Horizonte. Anais XVIII Encontro Nacional de Economia Política, 2013.
} 
Nas palavras de Novais e Arruda, "se, como historiadores, considerarmos a Economia Política uma ciência social, então a sequência temporal das ideias econômicas começará a ser vista em correlação aos contextos históricos, dentro dos quais se formularam e sobre os quais incidiram" ${ }^{50}$.

Analisando as determinações históricas nacionais do conhecimento, Paula, Cerqueira \& Albuquerque ${ }^{51}$ caracterizam a Economia Política clássica como uma invenção inglesa, resultado do contexto, da realidade e da cultura inglesa do período de emergência e consolidação do capitalismo.

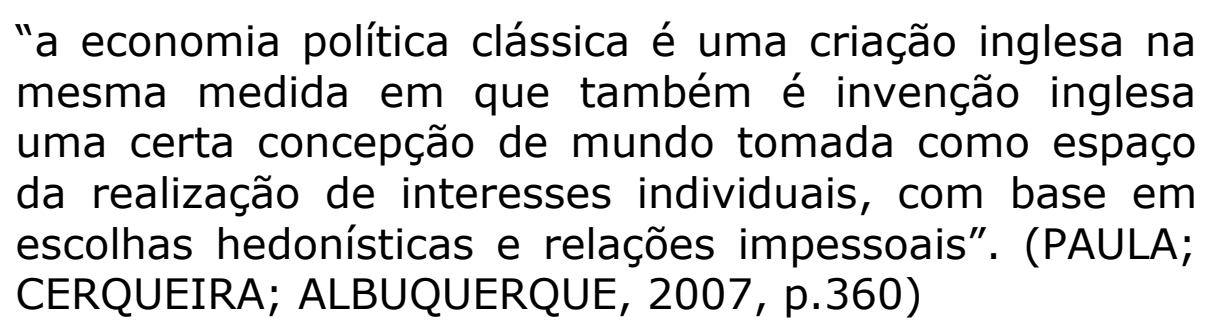

Para os autores, parece claro que o pensamento econômico reflete as circunstâncias históricas específicas do tempo e lugar em que é concebido, ou seja, o caráter nacional do pensamento econômico não pode ser ignorado. Da mesma forma que a suposta universalidade da Teoria Econômica ignora o fato que as Nações e sociedades têm histórias, padrões de comportamento e matrizes culturais distintas, e que influenciam de maneira decisiva a visão que têm da realidade e do mundo. Afirma-se, portanto, que a Economia, como toda ciência social, é uma leitura de um tempo e de uma realidade e por isso sua apropriação tem variadas formas. Neste sentido, os autores argumentam que seria possível falar e abordar diferentes estilos de economia política, que determinaram escolas nacionais de pensamento econômico, tanto no que diz respeito à forma, quanto ao conteúdo destas construções teóricas.

\footnotetext{
${ }^{50}$ NOVAIS, Fernando Antonio; ARRUDA, José Jobson de Andrade. Prometeus e Atlantes na forja da Nação. Economia e Sociedade, Campinas, v. 12, n. 2 (21), 2003.

${ }^{51}$ PAULA, João Antonio; CERQUEIRA, Hugo; ALBUQUERQUE, Eduardo. Nações e estilos de Economia Política. Revista de Economia Política, vol. 27, no 3 (107), pp. 357-374, julho-setembro/2007.
} 
"o pensamento econômico reflete, em algum sentido, o conjunto das circunstâncias histórico-culturais que 0 forjaram e que o viram nascer. Dizer isso - é importante frisar - não significa negar a existência de uma dimensão autônoma, interna, regida por leis e procedimentos analítico-científicos, determinante decisivo da constituição de todo campo específico de conhecimento. Significa, na verdade, interrogar a justeza da tese de Schumpeter sobre a existência de uma dimensão do pensamento econômico, a análise econômica, que seria imune a contaminações ideológico-políticas, eternamente voltada para um único objetivo - o desenvolvimento dos métodos de análise econômica no sentido de sua plena aproximação do prevalecente nas ciências exatas e naturais.

Assume-se aqui que o pensamento econômico, em que pese certa autonomia discursiva, certas exigências metodológico-conceituais, reflete o seu tempo e o seu lugar, expressa-se segundo estilos, metáforas, referências, interesses que transcendem o específico da análise econômica. Trata-se, assim, de entender 0 pensamento econômico, como, em alguma medida, refletindo o contexto nacional, as circunstâncias históricas que o ensejaram". (PAULA; CERQUEIRA; ALBUQUERQUE, 2007, p. 357-358)

A questão da nacionalidade do pensamento econômico talvez tenha sido pela primeira vez abordada por Friedrich List $^{52}$. O autor alemão argumenta que o sistema econômico criado por Adam Smith seria uma teoria nacional, ou o "sistema nacional de economia inglesa", e não uma "teoria pura" ou universal. Isto seria resultado de uma análise que se baseava nas especificidades da condição inglesa, que em muito se diferenciava da Alemanha de List e dos Estados Unidos, por exemplo. Tais diferenças de desenvolvimento constituíram a primeira parte do trabalho clássico do economista alemão. Logo, a Economia Política, em meados do século XIX, oferecia uma análise que, distante da realidade inglesa de desenvolvimento considerável no campo industrial, faria pouco sentido.

A Alemanha, assim como os Estados Unidos, se atrasou, em relação à Inglaterra, no processo da revolução industrial e, por isso, "precisava

52 LIST, Georg Friedrich. Sistema nacional de economia política. São Paulo: Abril Cultural, 1983. 
adotar, pois, atitude diversa na defesa de seus interesses, ao contrário do que preconizava a escola clássica, fruto da ideologia do capitalismo britânico". (IGLESIAS, 1959, p.51) Tal abordagem sustentaria, portanto, uma visão nacionalista em defesa do desenvolvimento industrial alemão.

Assim, List critica a defesa do livre cambismo como modelo teórico para todas as nações. O que não quer dizer que ele discordasse do liberalismo como regime econômico. Acreditava, portanto, no liberalismo como regime a ser seguido internamente pelos países, mas defendia o protecionismo comercial como forma de proteção às indústrias nascentes, que, do contrário, seriam destruídas antes de sua expansão, como resultado do atraso relativo em relação à indústria inglesa.

A defesa da proteção à indústria nascente surge como uma reação à entrada de produtos ingleses, através do livre câmbio, que impedia o surto industrial em países como Alemanha e Estados Unidos. Diante desta realidade, List discordará da escola clássica apontando o seu caráter ahistórico e abstrato e criticando sua pretensão universalizante ao formular leis supostamente válidas em qualquer tempo e lugar.

O que o autor alemão nos mostra é que a economia política, em seu nascimento, é o resultado de uma leitura de uma realidade específica, a inglesa do final do século XVIII e início do XIX, e uma defesa dos interesses imediatos daqueles que compunham tal realidade. Ou seja, o livre comércio servia aos interesses industriais da Inglaterra, mas em nada contribuiria para o progresso das nações em condições econômicas diferentes ${ }^{53}$.

\footnotetext{
${ }^{53}$ Inevitável não recordar aqui de estudo mais contemporâneo de Ha-Joo Chang que nos mostra como as nações industriais e desenvolvidas se utilizaram de artifícios reconhecidamente não liberais em suas estratégias de desenvolvimento e, principalmente a partir do final do século passado, defendiam que as nações subdesenvolvidas ou em estágio de desenvolvimento se utilizassem de estratégias liberais, principalmente o livre comércio, como forma de se desenvolver. Para Chang esta seria uma forma de limitar ou impedir o desenvolvimento de tais países e garantir uma condição de desigualdade que somente favorece os países desenvolvidos. Ver CHANG, Há-Joo. Chutando a Escada: a estratégia do desenvolvimento em perspectiva histórica. São Paulo: Ed. Unesp, 2004.
} 
O elemento da nacionalidade pode ser verificado também em uma das elaborações ${ }^{54}$ de História do Pensamento Econômico de Marx ${ }^{55}$, que, ao procurar estabelecer a gênese da economia política clássica, reconhece as diferentes determinações desta, na Inglaterra e na França. Assim, a teoria do valor do trabalho teria diferentes desdobramentos nas duas nações, cujo contraste se percebe nos trabalhos fundadores de William Petty e Pierre Boisguillebert no final do século XVII e início do XVIII e nas obras, consideradas como ponto de chegada ou de síntese da economia política por Marx, de David Ricardo e Simonde de Sismondi ${ }^{56}$, ou mesmo nos escritos clássicos de François Quesnay e Adam Smith. (Paula, Cerqueira \& Albuquerque, 2007)

"Se por um lado, esta polêmica contra o dinheiro está ligada a circunstâncias históricas determinadas Boisguillebert combatendo a cega e destruidora ganância do ouro da corte de Luis XIV, de seus "arrendatários gerais" e de sua nobreza, enquanto Petty exalta a ganância pelo ouro como o impulso enérgico que estimula um povo ao desenvolvimento industrial e à conquista do mercado mundial -, por outro lado, destaca-se aqui a profunda oposição de princípios, que se repete como um contraste permanente, entre a economia caracteristicamente inglesa e a caracteristicamente francesa". (MARX, 1974, p.162)

Tal contraste não foi completamente explorado por Marx, mas, sobretudo, se expõe nas denúncias que Boisguillebert e Sismondi fizeram de certos aspectos centrais do capitalismo, o dinheiro e o capital industrial, na dificuldade de aceitar certos elementos da dinâmica capitalista. Na essência, apresentam o que é central nas diferenças entre Inglaterra e França. Ainda que tenham sido espaços que, em períodos

\footnotetext{
${ }^{54}$ Para tal questão ver PAULA, João Antonio; CERQUEIRA, Hugo. Sobre Isaac Rubin e sua História do Pensamento Econômico. Apresentação In: RUBIN, Isaac. História do Pensamento Econômico. Rio de Janeiro: Ed. UFRJ, 2014.

${ }^{55}$ MARX, Karl. "Para Crítica da Economia Política". São Paulo: Abril Cultural, 1974. E PAULA, João Antonio; CERQUEIRA, Hugo; ALBUQUERQUE, Eduardo. Nações e estilos de Economia Política. Revista de Economia Política, vol. 27, no 3 (107), pp. 357-374, julhosetembro/2007.

${ }^{56}$ Que apesar de suíço é considerado francês por Marx a partir da leitura das nações como manifestação histórico-cultural.
} 
semelhantes, o capitalismo penetrou e se consolidou, enquanto na primeira o espírito e a garantia das liberdades individuais influenciaram de modo decisivo a vida material, intelectual e política da sociedade, na segunda, ao contrário, sempre prevaleceu a presença forte, absolutista do Estado, seja como indutor econômico ou reformador social. Duas matrizes culturais e intelectuais distintas que condicionarão a realidade bem como as apropriações teóricas que se farão dela.

"Se a França é, desde o início do século XVII, pelo menos, a exacerbação do poder absolutista, a Inglaterra vive, ainda mais precocemente, desde 0 início do século XIII, com a Carta Magna, a presença de limitações ao poder da monarquia, uma realidade que foi chamada de absolutismo mitigado. É essa tradição que marcará a trajetória político-institucional da Inglaterra até hoje - a longa experimentação de formas de garantia dos direitos individuais, uma permanente supremacia dos interesses dos homens de negócio sobre os privilégios aristocráticos. É essa a base tanto da mais arejada concepção de mercantilismo, que vai prevalecer na Inglaterra, quanto do enraizamento das prerrogativas da sociedade civil inglesa contra o discricionário do poder monárquico. (...) Muito outra é a ambiência histórica francesa. Lá prevaleceu, entre os séculos XVII e XIX, a mão pesada do estado absolutista em todo o seu poderio. Lá, ao contrário da afirmação dos interesses individuais, que é típica da realidade inglesa, prevalecerão a regulamentação e a interferência estatais, a concentração absoluta do poder monárquico, a ausência de instituições político-representativas capazes de vocalizar os interesses do "terceiro estado". É esse pano de fundo histórico que condicionará o pensamento econômico francês". (PAULA; CERQUEIRA; ALBUQUERQUE, 2007, p.359-360)

Dentro desta perspectiva, que considera as determinações históricas e culturais como fundamentais para a construção de um pensamento econômico, é inevitável não abordar o pensamento alemão, que se configurou em meados do século XIX e ficou conhecido como a Escola Histórica Alemã. São consagradas, na historiografia, as diferenças materiais e econômicas entre a Inglaterra e a Alemanha em meados do 
século XIX. Enquanto os ingleses viviam um ambiente no qual o capitalismo, bem como o desenvolvimento da indústria, já se consolidavam plenamente, os povos de origem germânica ainda estavam envolvidos na superação de complexas diferenças regionais, políticas e econômicas que marcam todo o processo de unificação da Nação, que apenas se consolidará na década de 1870. Estas realidades distintas marcam profundamente a produção e a reflexão intelectual nos dois espaços.

Como já destacamos anteriormente, todo ambiente cultural e social inglês favorecerá o desenvolvimento da Economia Política e de uma perspectiva liberal marcante na sociedade. Enquanto isso, na Alemanha, além de uma matriz cultural distinta, havia uma consciência do seu atraso relativo a outras nações. É dentro desta perspectiva que podemos compreender, por exemplo, as ideias de List destacadas anteriormente.

De certa forma, esta tradição de pensar a economia a partir da perspectiva histórica e nacional, inaugurada por List, influenciará e dará origem à Escola Histórica, da qual o alemão pode ser considerado um precursor. Muito se fala, mas na verdade pouco se conhece, estuda ou entende tal escola no Brasil ${ }^{57}$. É o que explica talvez a pouca quantidade de trabalhos específicos deste tema. Evidentemente que não é nosso interesse aqui resolver esta questão, sendo tão somente entender as contribuições metodológicas de tal escola para a abordagem do pensamento econômico em termos nacionais.

Essencialmente, a Escola Histórica rejeitou a economia política clássica (inglesa para colocar nos termos que tratamos aqui) e sua teoria do valor, assim como também rejeitou os paradigmas da economia

\footnotetext{
${ }^{57}$ Especificamente aqui nos valemos dos seguintes trabalhos para desenvolver esta parte: BEAUCLAIR, Geraldo. Introdução ao Estudo do Pensamento Econômico. Rio de Janeiro: Ed. Americana, 1974; IGLÉSIAS, Francisco. Introdução à historiografia econômica. Belo Horizonte: FCE/UFMG, 1959; PAULA, João Antonio; CERQUEIRA, Hugo; ALBUQUERQUE, Eduardo. Nações e estilos de Economia Política. Revista de Economia Política, vol. 27, no 3 (107), pp. 357-374, julho-setembro/2007; SCHUMPETER, Joseph. História da Análise Econômica. $3^{\circ}$ Volume, Rio de Janeiro: Fundo de Cultura, 1964b.
} 
neoclássica ${ }^{58}$. Assim, diante da realidade de uma economia atrasada e pouco desenvolvida, a escola alemã expõe nada mais que a opção por uma estratégia de desenvolvimento ou de superação do atraso que reafirma e valoriza a cultura e a identidade alemã, afirmando a importância da história e negando pressupostos e proposições que thes são culturalmente estranhas. Tal alternativa é resultado do ambiente, dos valores culturais, de uma determinada forma de ver a vida e da existência de uma sociedade na Alemanha que em muito se distinguia da Inglaterra.

"A recusa alemã em aceitar a economia clássica ou neoclássica é, na verdade, uma estratégia de afirmação de um outro paradigma que, opondo-se à impessoalidade, à abstração e ao individualismo típicos daquelas teorias, buscará mostrar a organicidade das relações entre o homem e a natureza, denunciando a inautenticidade do mundo da racionalidade instrumental, mediante a escolha da cultura em contraposição à civilização; da comunidade em relação à sociedade; da nação, do local, do regional em relação à abstração das relações impessoais". (Paula; Cerqueira; Albuquerque, 2007, p.366)

Ou nas palavras de Beauclair,

"Os teóricos da economia alemã, por volta de 1840, não podiam admitir a doutrina clássica inglesa, deduzida do princípio do próprio interesse, simplesmente por que este princípio não prevalecia em seu país. Nada mais natural de parte dos alemães do que a conviç̧ão de que uma investigação de caráter especial das economias nacionais era a primeira necessidade" (BEAUCLAIR, 1974, p.75)

Assim, a Escola Histórica rejeitou qualquer possibilidade de constituição de uma teoria econômica com pretensões universalizantes, ao

\footnotetext{
58 Mesmo tendo sido um alemão, Hermann Gossen em Desenvolvimento das leis relativas ao intercâmbio humano, de 1854, o precursor da economia neoclássica, ao tentar provar que a conduta humana era movida pelo intuito de obter o máximo de prazer, bem como, "um indivíduo que consome várias doses sucessivas de um mesmo bem econômico encontra no consumo de cada uma delas uma satisfação decrescente; e é a satisfação que procura a última dose a consumir (a que dará saciedade) a que determinará o valor do bem. A utilidade (a que mais tarde se denominou de marginal) seria para Gossen, a utilidade de um bem que, acrescido 'a quantidade total em poder do consumidor, satisfaz a necessidade dele' ". (BEAUCLAIR, 1974, p.83-84) Assim, seria a utilidade que determinaria o valor de um bem.
} 
tentar observar regularidade ou estabilidade nas relações econômicas. Para tal escola, a principal característica da economia seria a falta de regularidade ou a ausência de alguma ordem nos fenômenos econômicos. A existência de uma teoria econômica implicaria na possibilidade de previsão, o que, segundo eles, seria impossível em economia. Desta forma, a única alternativa seria recorrer à história como forma de entender os elementos da vida material.

Joseph Schumpeter, no terceiro volume de sua História da Análise Econômica, procura descrever os principais elementos da Escola Histórica alemã. $E$, aqui, um parênteses se faz necessário, pois, apesar de tal descrição, o autor não considera que tal corrente tenha feito contribuições ao que ele expõe como a Análise Econômica. Contudo, em seu entendimento, teria o que acrescentar do ponto de vista do ensino e da pesquisa na economia, sobretudo por ter sido ela uma das fundadoras da História Econômica, que em muito interessava ao economista austríaco ${ }^{59}$.

Ao tentar descrevê-la, divide em três gerações: "a velha escola histórica" formada por autores como Wilhelm Roscher (1817-1894), Bruno Hildebrand (1812-1878) e Karl Knies (1821-1898); "a nova escola histórica" cujo grande expoente foi Gustav Von Schmoller (1838-1917) ${ }^{60}$; e a "novíssima escola histórica" cujos expoentes foram Max Weber (18641920), Werner Sombart (1863-1941) e Arthur Spiethoff (1873-1957).

Francisco Iglesias (1959) parece discordar de tal abordagem ${ }^{61} \mathrm{e}$ divisão ao argumentar que não haveria "solução de continuidade" entre as

\footnotetext{
59 "Aquela conquista, embora culminante, não pertence, evidentemente, à esfera da análise científica. E uma vez que este livro é uma história da análise científica, não nos caberia tratar deste assunto. O que nos compete tratar aqui é outro de seus aspectos cuja menor importância eu me apresso a confirmar - qual seja a sua influência sobre a pesquisa e o ensino". (SCHUMPETER, 1964b, p.69-70)

${ }^{60}$ Além dele Schumpeter cita também Lujo Brentano (1844-1931), G. F. Knapp (18421926), Karl Bucher (1847-1930) e Held, de quem não conseguimos consultar maiores informações, uma vez que as notas de Schumpeter estão incompletas.

${ }^{61}$ Não é possível saber se Iglesias teve acesso ao trabalho de Schumpeter ao escrever o seu texto. O seu livro é de 1959 e a primeira publicação de História da Análise Econômica data de 1954, sendo que a tradução para o português ocorreu em 1964. Há que se ressaltar, também, que as referências citadas por Schumpeter não permitem saber de onde tirou tal divisão ou se trata de uma abordagem original. O seminal trabalho do economista austríaco, por se tratar de publicação póstuma organizada por sua esposa,
} 
gerações. Além disso, parece discordar da classificação de Weber e Sombart como membros da mesma, por acreditar que eles, "autores de universal repercussão", não seriam estranhos a ela, porém "em posição de independência ou até de hostilidade". (IGLESIAS, 1959, p.54)

Segundo Schumpeter, a principal carcterística da Escola Histórica era a crença "na proposição de que o economista, como pesquisador, deve ser um historiador econômico". Assim, a economia deveria basear-se em estudos exclusivamente históricos e o economista deveria "investigar processos e padrões de desenvolvimento em seus detalhes vivos, no tempo e no espaço, atividade cujo sabor teria que aprender e apreciar". (SCHUMPETER, 1964b, p.75)

Evidentemente, o trabalho do economista austríaco, que é uma grande demonstração de sua erudição e conhecimento, tem mais o sentido de descrição e análise dentro de uma perspectiva que valoriza muito mais a Escola Histórica como fundadora e propagadora da história econômica, do que propriamente uma abordagem que valorize a perspectiva crítica em relação à teoria econômica e como uma alternativa nacional à mesma. Apesar disso, o próprio Schumpeter relaciona a emergência de tal escola às especificidades alemãs do século XIX.

Segundo aponta Iglesias (1959) a Escola Histórica se inicia com Wilhelm Roscher, contemporâneo de List, porém mais liberal e não defensor do protecionismo. Assim, sua visão ainda se apega à escola clássica, defendendo, contudo, o culto à história como forma de fundamentar a sua obra de economista. Bruno Hildebrand foi o seu sucessor mais importante, tendo se afastado mais dos clássicos pela negação das leis naturais e preocupação com o desenvolvimento das nações. De uma forma geral, ainda procura encontrar princípios gerais para explicar a história econômica, o que de certa forma contradiz o próprio espírito de sua obra. Já Karl Gustav Knies dá o passo adiante da escola ao não reconhecer as leis naturais, as leis de desenvolvimento, 
conduzindo, assim, o relativismo a uma forma extrema e que não admitia generalizações.

"Desenvolve-se, pois, entre os três mestres da escola, o que se tem chamado "a querela das leis". Como conclusão, poder-se-ia dizer que se chega à possibilidade de negar a ciência econômica, pelo não reconhecimento de leis: a realidade é fruto de determinadas circunstâncias, em determinado tempo. Impõe-se um relativismo. A generalização que a economia clássica pretende repousa, então, em equívoco". (IGLESIAS, 1959, p.53)

Contudo, foi com Gustav Schmoller que a Escola Histórica teve o seu maior impulso com trabalhos cuja marca principal seria o fundamento histórico da economia. Assim, sintetiza Iglesias (1959), os traços marcantes da Escola Histórica foram: negação do universalismo das leis na economia política, uma vez que, diante de ambientes, contextos e realidades distintas, seria impossível estabelecer uma lei que pudesse ser válida em qualquer tempo e espaço e a negação do homo oeconomicus, movido pelo desejo insaciável de obter cada vez mais riqueza, uma vez que o indivíduo poderia obedecer a outros impulsos. Portanto, para os historicistas seria impossível, inviável e questionável a construção de uma teoria econômica abstrata e universal, uma vez que não se poderia levar em conta o geral, mas apenas o particular, o específico.

"Em síntese, exaltando o papel da história em economia, a ponto de torná-la fundamento e centro da ciência econômica - que só se constituiria diante de materiais históricos e estatísticos sobre as condições econômicas dos povos em todos os pontos e épocas -, essa corrente teve o mérito de fazer estudo sem conta". (IGLESIAS, 1959, p.61)

Trata-se, portanto, de uma questão metodológica o elemento central da Escola Histórica, como bem chama atenção Francisco Iglesias. Tal abordagem, ao criticar o universalismo, valorizar a história e abrir espaço para a questão da nacionalidade, em muito nos interessa no que 
diz respeito à construção e à possibilidade de um pensamento econômico nacional.

Colocada a questão metodológica, como, então definir um pensamento econômico nacional? Tal questão foi sistematicamente discutida por José Luiz Cardoso em seus trabalhos a respeito do pensamento econômico português e da difusão das ideias econômicas na Europa. ${ }^{62}$ Para o autor, a historiografia do pensamento econômico tradicional não deu atenção suficiente às ideias e teorias desenvolvidas em contextos históricos e espaços nacionais que não os específicos dos países capitalistas centrais.

Levando em conta a perspectiva do absolutismo e relativismo, para o autor, não haveria como seguir a abordagem absolutista para o caso de Portugal, uma vez que o país padeceria de escassez de produção analítica ${ }^{63}$. Cardoso adota, desta forma, a abordagem relativista, sendo que considera não ser "possível compor uma história nacional do pensamento econômico sem atender aos nexos e ligações mantidos à escala internacional". (CARDOSO, 2001, p. 12)

Desta forma, o autor aponta para o que seria a questão central, como estabelecer a relação entre cosmopolitismo, que seria a recepção e difusão da teoria econômica estrangeira no âmbito nacional, e a nacionalidade. O que significa dizer que existiria, de um lado, uma história do pensamento econômico internacional, abstrata, teórica e alheia às especificidades históricas e regionais e, de outro, histórias do pensamento econômico nacional, presentes sobretudo nos países periféricos, e resultado da apropriação e adaptação do pensamento internacional às necessidades, especificidades e realidades nacionais. Dito de outra forma, e no essencial, a questão permanece e o pensamento econômico

\footnotetext{
${ }^{62}$ Além dos trabalhos já citados do autor, ver CARDOSO, José Luís, Reflexões periféricas sobre a difusão internacional do pensamento econômico. Nova Economia. vol.19 no.2, Belo Horizonte Mai/Set., 2009; CARDOSO, José Luís, The International Diffusion of Economic Thought. In: SAMUELS, Warren; BIDDLE, Jeff E.; DAVIS, John B. (eds) A companion to the history of economic thought. Oxford, England: Blackwell Publishing, 2007.

${ }^{63}$ Cardoso argumenta nos mesmos termos que Bielshowsky para o caso do Brasil, como analisaremos mais detidamente à frente no capítulo.
} 
internacional e os pensamentos econômicos nacionais convivem assim como a análise econômica e o pensamento econômico na tipologia schumpeteriana. (COSENTINO; GAMBI; SILVA, 2013) Assim, a principal preocupação de José Luiz Cardoso é a difusão e assimilação internacional do pensamento econômico.

"a facilidade ou dificuldade de aceitação de doutrinas, teorias e políticas econômicas está sempre condicionada pelas particularidades da realidade econômica, das instituições políticas e sociais e do ambiente científico prevalecente no país receptor. Ora, é precisamente o modo como um país utiliza e adapta as influências recebidas que torna pertinente e válido o estudo da história do pensamento econômico numa perspectiva nacional". (CARDOSO, 2009, p.254)

Para o autor, a originalidade das ideias nacionais estaria ligada às especificidades vividas por cada país, não se podendo negar a existência de centros difusores do conhecimento. Portanto, a originalidade estaria diretamente ligada à uma adaptação criteriosa da "matriz de reflexão comum" ou do pensamento internacional, sendo que as novidades necessárias para adaptar a teoria à realidade nacional garantem a possibilidade e a formação de um pensamento nacional.

Assim, a difusão do pensamento econômico em escala internacional se apresenta como uma condição de possibilidade ao pensamento econômico nacional, bem como garante às ideias econômicas sua própria universalidade, ao rasgar horizontes e fronteiras, aparecendo em diferentes espaços e territórios. (CARDOSO, 2009)

Evidentemente, esta perspectiva significa a existência de pioneiros e seguidores, em termos de pensamento econômico, sendo que o pioneirismo caberia sempre ao centro, restando à periferia o papel de seguidores. Portanto, o centro produz o conhecimento ou a teoria internacional e a periferia, subordinada, em seguida, o adapta à sua realidade específica e conforme sua necessidade. Assim, para a periferia, a questão da nacionalidade, no que diz respeito ao pensamento econômico, é uma questão essencial. Como bem lembra Cardoso, não se 
trata apenas de uma questão de afirmação da identidade nacional, mas sim "da identificação de problemas nacionais para os quais são necessárias soluções nacionais; pois é no diagnóstico desses problemas e na sua resolução que emergem formas inovadoras e genuinamente nacionais de pensamento económico". (CARDOSO, 2001, p. 213-214).

Assim, a originalidade do pensamento econômico na periferia do capitalismo seria decorrente da adaptação da teoria internacional, nas palavras de Cardoso, uma adaptação original. Tais questões, no âmbito do Brasil, tiveram tratamento semelhante por Amaury Gremaud e Ângela Ganem.

Amaury Gremaud ${ }^{64}$ fala em originalidade, a partir da adaptação, sobretudo quando discute as ideias do Visconde de Cairu, o Ensino de Economia Política no Brasil no século XIX e o debate entorno da política monetária. Já Ângela Ganem ${ }^{65}$, discutindo questões mais relativas ao século XX e à consolidação do capitalismo no Brasil, aponta na adaptação teórica e conceitual uma marca da história do pensamento econômico brasileiro, assim como a pluralidade e a interdisciplinaridade.

Por outro lado, Geraldo Beauclair ${ }^{66}$ argumenta que a originalidade e a adaptação não seriam os únicos caminhos para o estudo do Pensamento Econômico Brasileiro no século XIX. Para o autor, esta seria uma possibilidade, decorrente da análise de como os pensadores brasileiros, partindo da matriz teórica da fisiocracia ou da economia política clássica inglesa, refletiram sobre a realidade brasileira. Por outro lado, haveria uma série de outros personagens que, prescindido desta matriz teórica tradicional, pensaram o cenário econômico brasileiro e, na visão do autor, conceberam uma verdadeira e genuína "Economia Política Nacional", nos moldes e a partir da mesma tradição da "Escola Histórica Alemã" que,

${ }^{64}$ GREMAUD, Amaury. P. Das controvérsias teóricas à política econômica. Tese de doutorado. Universidade de São Paulo. 1997.

${ }^{65}$ GANEM, Ângela. Reflexões sobre a história do Pensamento Econômico Brasileiro. Análise Econômica, v.59, n.26, 2011.

${ }^{66}$ BEAUCLAIR, Geraldo. M. O. A construção inacabada: a economia brasileira (18201860). Rio de Janeiro: Vício de leitura, 2001. 
como vimos, também rejeita a escola liberal inglesa como única via teórica para pensar as questões econômicas.

"Para os ilustrados que trilharam esta última via fazer Economia Política seria, então, vivenciar as situações, observar as fazendas e oficinas, descrever 0 funcionamento das instituições, procurar perceber as 'realidades' circundantes, formar uma 'ideia' dessas 'realidades' e propor medidas julgadas adequadas ou possíveis de serem postas 'em prática'". (BEAUCLAIR, 2001, p.117)

Discutida a questão da possibilidade de um pensamento econômico nacional, bem como sua definição em torno da adaptação e da originalidade, cabe agora, como base nestes aspectos, definir o Pensamento Econômico Brasileiro e sua possibilidade de discussão a partir do século XIX.

Qualquer reflexão ou discussão a respeito do Pensamento Econômico Brasileiro passa obrigatoriamente pelos trabalhos de Ricardo Bielschowsky e Guido Mantega ${ }^{67}$. Os dois trabalhos clássicos são da década de 1980 e, apesar de partirem de metodologias diferentes, concentram suas análises e discussões em torno da temática do pensamento desenvolvimentista no Brasil. Assim, centram suas pesquisas em mostrar como autores e pensadores encaravam e interpretavam os problemas do Brasil e os meios possíveis para o país se desenvolver.

Em A Economia Política Brasileira, Guido Mantega procura identificar como se formou e estruturou nossa economia política. Logo na introdução, Mantega identifica Formação Econômica do Brasil, de Celso Furtado, como a obra fundante da economia política brasileira. Antes, para ele, as análises se encontravam de forma parcial e fragmentadas, logo, o trabalho de Furtado, segundo o autor, era o primeiro trabalho de fôlego, estruturado a partir de um sólido arcabouço teórico, que organiza e procura compreender a dinâmica econômica brasileira. A partir desta obra, para Mantega, o Pensamento Econômico Brasileiro se consolidou e

67 BIELSCHOWSKY, Ricardo. Pensamento Econômico Brasileiro: o ciclo ideológico do desenvolvimentismo. Rio de Janeiro: Contraponto, 2004; MANTEGA, Guido. A Economia Política Brasileira. São Paulo/Petrópolis: Vozes, 1985. 
passou a formar modelos analíticos. Assim, o autor pretende, com a obra, analisar a formação destes modelos, suas origens teóricas, fontes de inspiração, hipóteses básicas e proposições fundamentais. Desta forma, "trata-se, portanto, da reconstituição crítica das trajetórias teóricas das principais correntes analíticas afins, que vão formar, no meu entender, uma Economia Política Brasileira." (MANTEGA, 1984,18).

Para Mantega, o Pensamento Econômico Brasileiro formou-se ao longo do anos de 1950 e 1960, a partir da consolidação dos processos de urbanização e industrialização do Brasil, ou seja, a partir da consolidação do capitalismo. Processo que desencadeou interpretações sobre o subdesenvolvimento brasileiro e os meios para superá-lo. Assim, através da influência, seja da teoria econômica clássica, keynesiana ou marxista, nascem diversas interpretações da realidade brasileira, contudo, o essencial, e o que tornou possível falar-se em uma economia política brasileira, foi a criatividade e a originalidade das contribuições e suas preocupações com as peculiaridades históricas brasileiras. De tal modo, tais interpretações e visões teóricas tornaram relevante e fundamental em suas estruturas a formação econômica e capitalista brasileira, ou seja, como as relações capitalistas ou o modo de produção capitalista se desenvolveu no país.

Assim, o autor analisa o pensamento econômico brasileiro entre as décadas de 1950 e 1970 e o divide em correntes de pensamento, que construíram quatro modelos analíticos, são eles: Modelo de Substituição de Importações, Modelo Democrático-Burguês, Modelos de Subdesenvolvimento Capitalista e Modelo Brasileiro de Desenvolvimento. O primeiro modelo é oriundo das interpretações de Celso Furtado, Ignácio Rangel e Maria da Conceição Tavares, sendo herdeiro das ideias da Cepal e de figuras como Raul Prebisch, Ragnar Nurkse, H. W. Singer e Gunnar Myrdal. O segundo modelo é oriundo das interpretações dos teóricos do Partido Comunista Brasileiro e sistematizado por Nelson Werneck Sodré e Alberto Passos Guimarães, com inspiração das análises de Lênin e retomando as teses da III Internacional para os países atrasados. O 
terceiro modelo advém dos trabalhos de André Gunter Frank, Caio Prado Jr. e Rui Mauro Marini, baseado no marxismo norte-americano de Paul Baran e Paul Sweezy, sob influência da Teoria da Revolução Permanente de Trotsky e das teses da IV Internacional. O quarto modelo, de expoentes como Roberto Campos e Mario Henrique Simonsen, tem inspiração conservadora e se opõe aos demais de inspiração crítica ou mais à "esquerda"; foi colocado em prática a partir do Golpe de 1964, aliando a adaptação dos princípios neoclássicos liberais à necessidade de grande intervenção do Estado na economia, através da criação de empresas estatais e na regulação da força de trabalho, potencializando os lucros através da deteriorização salarial.

Não é nosso intuito analisar profundamente o trabalho e os modelos propostos por Mantega, entretanto, no que interessa à nossa discussão, o autor procura apresentar os modelos a partir da ideia de que todos partiram de teorias econômicas disponíveis, aplicando-as à formação social brasileira. Ou seja, são modelos que adaptaram formulações teóricas à realidade brasileira, em outras palavras, à realidade de um capitalismo retardatário e subdesenvolvido. Essa adaptação confere a eles originalidade, segundo Mantega.

Desta forma, os modelos analíticos propostos seriam criativos e originais ao adaptarem teorias já existentes e isso garantiria a eles a alcunha de formadores da economia política brasileira. Note-se que o autor procura fugir de questões metodológicas mais complexas a respeito da definição de pensamento econômico.

Já o trabalho de Ricardo Bielschowsky, Pensamento Econômico Brasileiro, adota a mesma tipologia de Schumpeter discutida anteriormente. O autor organiza seu livro a partir da noção de ciclo ideológico, baseado na noção schumpeteriana a respeito de pensamento econômico. Para ele, assim como para Schumpeter, a ideia de pensamento econômico estaria ligada a um conjunto de opiniões, posições 
ou interpretações relativas à política econômica ${ }^{68}$, ou seja, diferente da ideia de análise econômica. Logo, não haveria no país a possibilidade de se escrever uma História da Análise Econômica, dada a ausência de produção teórica e analítica. Para o autor, no Brasil, os economistas estavam mais interessados e envolvidos com questões práticas, ligadas diretamente aos dilemas nacionais e à política econômica que os resolveria, que com questões propriamente e puramente teóricas. Luiz Carlos Bresser Pereira69 levanta questão parecida ao afirmar que "os intelectuais brasileiros são mais pragmáticos e mais engajados no processo político do que os intelectuais dos países desenvolvidos" (BRESSER-PEREIRA, 1997, p.57) não havendo espaço, na periferia, para teorias abstratas. Dessa forma, a reflexão sobre a economia brasileira nos leva a um debate não teórico, mais prático e historicamente determinado. Deste modo, "a dimensão histórica do pensamento econômico e não seu conteúdo analítico, transformam-se, necessariamente, na linha-mestra de nosso estudo" (BIELSCHOWSKY, 2004: p.6).

Assim, o pensamento econômico analisado tem por núcleo a ideia de desenvolvimentismo, assim, Bielschowsky analisa o que ele definiu como ciclo ideológico do desenvolvimentismo, ou seja, sua formação, consolidação, auge e crise. Trata-se também, portanto, de um trabalho voltado para a relação entre o pensamento desenvolvimentista e o desenvolvimento econômico brasileiro, a industrialização.

Assim sendo, o autor define o conceito chave que organiza sua análise, o desenvolvimentismo como "a ideologia de transformação da sociedade brasileira definida pelo projeto econômico" composto do projeto da industrialização, com a participação efetiva do Estado, seja planejando ou promovendo investimentos, uma vez que o mercado seria incapaz de

\footnotetext{
${ }^{68}$ Como já visto anteriormente, posição algo parecida com a de José Luis Cardoso quando discute o caso de Portugal.

69 BRESSER-PEREIRA, L. C. Interpretações sobre o Brasil. In: LOUREIRO, Maria Rita (org.). 50 anos de Ciência Econômica no Brasil (1946-1996): pensamento, instituições, depoimentos. Petrópolis, RJ: Vozes, 1997.
} 
promovê-la. Esse seria o caminho para a superação da pobreza e do subdesenvolvimento.

Portanto, o trabalho de Bielschowsky, a partir da ideia geral do desenvolvimentismo, organiza o pensamento econômico brasileiro entre 1945 e 1964 em correntes, quais sejam, neoliberal, desenvolvimentista e socialista, além de apresentar o pensamento independente de Inácio Rangel.

A corrente neoliberal teria uma vocação neoclássica, liberal, contra a atuação do Estado na economia, favorável ao equilíbrio monetário e financeiro que combatesse a inflação e defensora da vocação agrária brasileira e, portanto, contrária a ideia de indução da industrialização através do incentivo estatal. Seus principais representantes eram Eugenio Gudin, Otávio Gouvêa de Bulhões, Dênio Nogueira e Daniel de Carvalho.

Já a corrente desenvolvimentista se dividiria em três outras correntes: desenvolvimentista no setor público não nacionalista, desenvolvimentismo no setor público nacionalista e desenvolvimentismo no setor privado. A corrente não nacionalista era representada por Roberto Campos, Lucas Lopes, Ary Torres e Glycon de Paiva e defendia a participação do capital estrangeiro na industrialização, uma atuação parcial do Estado na economia através do planejamento e a favor de políticas estabilizadoras que combatessem a inflação. A corrente nacionalista representada por Celso Furtado, Rômulo de Almeida, Américo Oliveira, Evaldo Lima e Roberto Simonsen, tinha influência cepalina, acreditava no planejamento e atuação estatal para promover a industrialização, acreditava que a inflação era um fenômeno estrutural que deveria ser combatido através das políticas de desenvolvimento e se portava favorável à reforma agrária. Por fim, os principais expoentes da corrente desenvolvimentista no setor privado eram Roberto Simonsen, João Paulo de Almeida Magalhães e Nuno Figueiredo, e acreditavam que a industrialização deveria ser pautada pela proteção do Estado ao capital industrial nacional. 
A corrente socialista organizava-se a partir do Partido Comunista Brasileiro (PCB) e do ISEB, e tinha como representantes Caio Prado Jr., Nelson Werneck Sodré, Alberto Passos Guimarães e Aristóteles Moura. Inspirados pelo materialismo histórico, acreditavam que 0 desenvolvimento capitalista era uma necessidade para a viabilização do socialismo. Deste modo, defendiam uma industrialização planejada e ancorada em bases nacionais e na reforma agrária, para assim romper com a dominação imperialista e com a concentração da renda e da terra, que impediam o país de crescer e se desenvolver.

Desde modo, Bielschowsky procura organizar o pensamento econômico brasileiro e o ciclo ideológico do desenvolvimentismo que, para ele, teve seu nascimento entre 1930 e 1945, sua maturação entre 1945 e 1955, seu auge entre 1955 e 1960 e sua crise entre 1960-1964.

Tanto Bielschowsky quanto Mantega trabalham com critérios de seleção parecidos e organizam o Pensamento Econômico Brasileiro entorno do debate a respeito do subdesenvolvimento $e$ do desenvolvimento econômico. Contudo, a forma como apresentaram e expuseram suas ideias é diferente, como verificamos anteriormente.

A questão metodológica é um aspecto fundamental a todos os trabalhos que pretendem abordar a história do Pensamento Econômico Brasileiro. A questão sobre o que é e como expor o Pensamento Econômico Brasileiro não é trivial e por isso sua discussão é difícil. São poucas as obras a respeito do tema e nem sempre elas se preocupam em responder tais questões.

Um trabalho importante foi o organizado por Maria Rita Loureiro ${ }^{70}$ : Oriundo de um Seminário organizado na USP, o trabalho toma como base a criação do curso de economia no Brasil e o desenvolvimento das instituições de pesquisa, dos departamentos de economia e dos cursos de graduação e pós-graduação no país. Assim, a obra procura sintetizar e apresentar um balanço, a respeito do Pensamento Econômico Brasileiro,

\footnotetext{
70 LOUREIRO, Maria Rita (org.). 50 anos de Ciência Econômica no Brasil (1946-1996): pensamento, instituições, depoimentos. Petrópolis, RJ: Vozes, 1997.
} 
através de textos de Luis Carlos Bresser Pereira, que reflete sobre as interpretações sobre o Brasil, discutindo as principais interpretações sobre a formação social e econômica brasileira, de Guido Mantega e Ricardo Bielschowsky, e apresenta sínteses de seus trabalhos já citados acima, além de um texto de Leda Paulani sobre a Teoria da Inflação inercial. Além disso, são discutidas as instituições de ensino e pesquisa em economia, desde o seu início, bem como o rumo que tomaram ao longo dos anos. É um trabalho importante pois reúne depoimentos de vários dos principais economistas do país.

Recentemente, o livro Ensaios de História do Pensamento Econômico no Brasil Contemporâneo, organizado por Tamás Szmrecsányi e Francisco da Silva Coelho ${ }^{71}$, procurou realizar um trabalho de síntese do Pensamento Econômico Brasileiro contemporâneo. Nota-se, pelos textos e pela organização da obra, a opção por abordar tema de forma abrangente e sob vários aspectos. Por um lado, adotou a contemporaneidade como critério para trabalhar com pensadores do século XX; por outro, abordou o tema tanto do ponto de vista individual, selecionando e apresentando a ideia dos pensadores individualmente, quanto procurou abordar o desenvolvimento da ciência econômica nas Universidades com a formação dos cursos de graduação e pós-graduação em economia nos principais centros do país, bem como as influências teóricas que o Pensamento Econômico Brasileiro sofreu e os principais temas abordados e debatidos pelos economistas brasileiros. Ao final, temos um trabalho ousado, de grande valor, exposto em 32 capítulos e envolvendo 35 economistas de diversas áreas e centros do país.

Um trabalho recente e que procura discutir questões metodológicas a respeito da história do Pensamento Econômico Brasileiro é o do grupo de pesquisa coordenado por Maria de Mello Malta ${ }^{72}$. Para eles, a questão metodológica é um problema para se estudar no período recente. De um

\footnotetext{
${ }^{71}$ SZMRECSÁNYI, Tamás; COELHO, Francisco da Silva (Orgs.). Ensaios de História do Pensamento Econômico no Brasil Contemporâneo. São Paulo: Atlas, 2007.

72 MALTA, Maria Mello de. Ecos do Desenvolvimento. Rio de Janeiro: IPEA, Centro Celso Furtado, 2011.
} 
lado, a influência dos trabalhos de Mantega e Bielschowsky, de outro, o desenvolvimento dos departamentos, centros de pesquisa e pósgraduação em economia, que permitiram a entrada das discussões econômicas nos campos acadêmicos e teóricos. Assim, não é mais possível retratar o pensamento a partir apenas das suas contribuições práticas e interpretativas da teoria econômica convencional, com vistas à um fim específico de política econômica, como fizeram Mantega e Bielschowsky para o período de 1930 a 1964.

Desta forma, incorporando uma produção acadêmica e teórica em desenvolvimento no país a partir da década de 1960, o grupo pretende estudar o pensamento econômico no período que Bielschowsky caracterizou como de crise do pensamento desenvolvimentista. Desta forma, caminha para um caminho semelhante ao do autor, tentando avançar sua proposta a um período contemporâneo. Assim, acrescenta novos argumentos metodológicos mas não se afasta muito do que o autor e também Mantega discutiram, ou seja, o pensamento econômico a partir da ideia unificadora do debate entorno do desenvolvimento. Certamente é difícil se livrar desta questão, que é central em qualquer discussão a respeito do país, seja em economia ou em qualquer outra ciência social. Trata-se, portanto, de um esforço de reflexão metodológico, anterior a qualquer estudo sobre História do Pensamento Econômico, que procura apresentar uma escolha de autores e temas, bem como um critério de escolha destes.

Outro trabalho importante é o de Ângela Ganem. Assim como os autores discutidos até agora, o foco de sua análise coloca o século $\mathrm{XX}$ como marco inicial da análise e o desenvolvimento como ponto central das discussões. Para autora, o Pensamento Econômico Brasileiro deve ser considerado a partir de sua relação com a própria história econômica do país, bem como a partir de adaptações criativas de conceitos da teoria econômica tradicional e da elaboração de conceitos próprios à nossa 
realidade. Para Ganem, o pluralismo e a interdisciplinaridade são aspectos essenciais do Pensamento Econômico Brasileiro. ${ }^{73}$

Portanto, as principais obras a respeito do Pensamento Econômico Brasileiro definem como marco inicial o século XX. Como podemos notar, o desenvolvimento é elemento unificador das ideias e preocupações, o que explica o recorte temporal das análises. Contudo, apesar de considerar as análises anteriormente ponderadas como importantes e fundamentais, acreditamos ter especial importância uma reflexão mais profunda a respeito do Pensamento Econômico Brasileiro no século XIX.

Geraldo Beauclair (2001) argumenta que, de uma forma geral, os economistas desconsideram o século XIX como período relevante para a história do Pensamento Econômico Brasileiro. Entendemos que tal escolha trata-se, antes de tudo, de opção metodológica, como expomos até aqui. Conhecendo bem a formação econômica do Brasil, sabemos que a estrutura econômica do país se altera do século XIX para o XX, sendo que sua condição periférica se mantém. Assim, estudar o Pensamento Econômico Brasileiro do século XIX ajuda a compreender a formação do Pensamento Econômico Brasileiro atual. Da mesma forma, estudar o Pensamento Econômico Brasileiro no século XIX é essencial para entender a formação desse pensamento na periferia e sua influência nas políticas econômicas adotadas.

A seguir discutimos alguns trabalhos que focam suas atenções no Pensamento Econômico Brasileiro no século XIX. Se, por um lado, podemos considerar que há certa escassez de pesquisas de história do Pensamento Econômico Brasileiro sobre esse período, por outro, um exame detalhado na literatura econômica e histórica nos faz descobrir alguns trabalhos sobre o assunto que nos ajudam a refletir a respeito das questões metodológicas discutidas anteriormente.

\footnotetext{
73 GANEM, Ângela. Reflexões sobre a História do Pensamento Econômico Brasileiro. Análise Econômica, v.59, n.26, 2011 \& Ganem, Ângela. A História do Pensamento Econômico Brasileiro como questão. In: MALTA, Maria Mello de. (org.) Ecos do desenvolvimento. Rio de Janeiro: IPEA, Centro Celso Furtado, 2011.
} 
Um trabalho pioneiro é o de Humberto Bastos, $O$ Pensamento Industrial no Brasil ${ }^{74}$, de 1952. O livro pretende dar um perfil ou fazer uma introdução à história do capitalismo industrial brasileiro, "e sua luta para sobreviver aos embates com o capitalismo comercial nascente, aliado às vivências do patriciado rural e aos interesses especificamente alienígenas" (Bastos, 1952, p.8). Articulando as ideias nacionalistas e protecionistas à história do desenvolvimento industrial brasileiro, o autor discute ideias de figuras fundamentais do pensamento econômico nacional.

O autor inicia o livro com uma introdução onde são apresentadas ideias de Ruy Barbosa. A ideia era desconstruir certa imagem negativa que se formou dele na história nacional, apresentando-o como um sonhador de "esforços heroicos" pelo desenvolvimento industrial brasileiro.

O capítulo seguinte discute basicamente as ideias industriais durante o século XIX, durante o período imperial. O autor procura mostrar como o livre-cambismo não favorecia aos países dependentes, como o Brasil, sendo favorável às nações industriais, como a Inglaterra. Além disso, mostra que os países que se desenvolveram praticavam o protecionismo. Assim, Bastos argumenta que desenvolvidos defendiam práticas e ideias econômicas que somente favoreciam a eles em detrimento do progresso das nações atrasadas. A partir destas questões, procura articular desde ideias e pensamentos de personagens e figuras brasileiras importantes durante o século XIX a episódios e exemplos da história nacional. Desta forma, argumenta que, apesar de, em muitos momentos, vários políticos, empresários ou intelectuais terem defendido ideias industrialistas, progressistas, que visavam ao desenvolvimento nacional, o que se nota são ações neutralizadas pelo interesse monárquico, ligados à uma elite agrária e rural, voltada para a produção agrícola direcionada ao comércio internacional. Assim, conclui que,

\footnotetext{
${ }^{74}$ BASTOS, Humberto. O Pensamento Industrial no Brasil. São Paulo: Livraria Martins Editora, 1952.
} 
"As ligações da monarquia com elites do capitalismo comercial, despreocupando-se propriamente da atividade industrial, e mesmo prejudicando-a com um certo estatismo, excetuando-se a indústria do açúcar, foi tão irritante que nos programas de agremiações políticas a partir dos três últimos decênios do século XIX encontra-se a exaltação da liberdade para a indústria e para o comércio e a revogação de privilégios e monopólios. Procuravam homens como Nabuco de Araujo, Souza Franco, Zacarias de Goes e Vasconcellos, Francisco José Furtado, Theophilo Benedicto Ottoni, Cunha Paranaguá e vários outros para reagirem contra a absorção monárquica, tentando estabelecer, com um regime de liberdade, melhor clima ao progresso nacional. Mas esse liberalismo já nos encontraria em posição altamente desfavorável na vida econômica internacional, expressa na dívida externa e na estrutura semi-colonial da nossa economia, e com a predominância, por isto mesmo, dos interesses rurais." (BASTOS, 1952, p.76-77)

Assim, para Humberto Bastos a mentalidade industrial no Brasil estava em formação no final do século XIX, início do século XX. Esta mentalidade enfrentava interesses importantes, tanto internos quanto externos. O autor analisa o período inicial da República e todo o debate entorno da adoção de medidas mais progressistas pelo governo. Para ele, nesse período, o pensamento industrial iria ganhar importância, se consolidar e forçar os governos a adotar medidas conciliadoras de interesses divergentes diante das ideias industrialistas.

A partir daí, o autor procura mostrar como as transformações mundiais durante o século XX e o avanço da urbanização no Brasil irão contribuir para o desenvolvimento do capitalismo nacional. Assim, o autor apresenta a consolidação do pensamento industrial no país e a formação do capitalismo brasileiro. Para o autor, este pensamento já se fazia presente, mesmo que não dominante, desde o século $X I X$, tendo se consolidado a partir das primeiras décadas do século $X X$, resultado das grandes transformações do Brasil e do cenário internacional.

Bastos conclui seu trabalho defendendo a ideia de que o capitalismo não é único e que não existe uma fórmula para se atingir o 
desenvolvimento e o progresso. Procura, assim, criticar àqueles que sempre defenderam ideias importadas, distantes da nossa realidade e ressaltar as ideias originais e preocupadas com o interesse nacional, com o desenvolvimento e melhor apropriação das riquezas. Para ele, "o nosso erro tem sido repetir axiomas estrangeiros e querer aplicá-los entre nós. Daí a ficção intelectual que se cria em relação ao Brasil em contraste com a sua realidade física." (BASTOS, 1952, p.213)

Deste modo, o critério de seleção de pensadores utilizado por Humberto Bastos leva em conta a questão do industrialismo e da originalidade de ideias que procuraram interpretar a realidade brasileira a partir de suas especificidades, sem difundir acriticamente pensamentos importados, propondo medidas de superação dos problemas econômicos nacionais. Portanto, seu critério parece claro e nos remete ao período em que seu trabalho foi concebido. A década de 1950, marcada pelo segundo governo de Getúlio Vargas e pelo governo Juscelino Kubitschek é, para muitos economistas e historiadores econômicos, o momento de consolidação da indústria nacional a partir da forte influência, gerenciamento e ação estatais.

Outro trabalho pioneiro é o de Paul Hugon, A Economia Política no $B_{\text {rasil }}{ }^{5}$, originalmente publicado em 1955 . Este texto é citado por grande parte dos trabalhos que abordam o pensamento econômico no Brasil durante o século XIX e o início do século XX. O autor divide o estudo em duas partes, de 1804 a 1930 e depois de 1930. Não há qualquer análise metodológica, contudo, em uma nota, o autor sintetiza os objetivos do seu estudo: "Nessas páginas trataremos de economia política brasileira: a fim de poder estabelecer uma ligação entre o presente estudo especializado e as questões gerais relativas ao ensino e à cultura brasileira" (HUGON, 1994, p.393).

O grande mérito do trabalho de Hugon é buscar analisar como a Economia Política foi introduzida no Brasil a partir do estudo do seu ensino

\footnotetext{
75 HUGON, Paul. A Economia Política no Brasil. In: AZEVEDO, Fernando de (org.). As Ciências no Brasil. 2a Ed., V.2., Rio de Janeiro: Editora UFRJ, 1994.
} 
nos cursos superiores no país. Para tanto, começa analisando a obra de José da Silva Lisboa, o Visconde de Cairu, e o seu pioneirismo a partir do seu Princípios de Economia Política de 1804 e de sua nomeação, por decreto real de D. João VI, em 1808, para ministrar a disciplina de Economia Política, que seria instituída no Brasil a partir de então. Ademais, procura valorizar as ideias de Cairu e negar a ideia de que seria um simples divulgador de Adam Smtih. Hugon apresenta José da Silva Lisboa como pensador que refletiu sobre Economia Política a partir da realidade brasileira e suas peculiaridades; como pensador original, defensor da indústria, que antecipou List e elaborou uma doutrina especificamente brasileira.

Ademais, Hugon procura analisar o ensino de Economia Política nas Faculdades de Direito, onde, segundo o autor, exclusivamente se ensinou a disciplina durante os anos de 1827 a 1863 . Sua análise se preocupa em mostrar os autores abordados e discutidos no ensino da disciplina e argumenta que ela não teve influência única e exclusivamente da economia política inglesa.

O autor analisa ainda o ensino da disciplina na Escola Politécnica, iniciado a partir de 1869. Assim, como no caso das Faculdades de Direito, procura apresentar os autores discutidos e apresentados nos cursos. Além disso, mostra como os responsáveis pela disciplina tiveram grande ligação com o poder público (José Maria da Silva Paranhos, o Visconde do Rio Branco, Aarão Reis, Vieira Souto) e como a disciplina estava voltada para a compreensão da situação da economia brasileira.

A partir da segunda parte, Hugon procura analisar a formação dos departamentos e cursos de economia, partindo da introdução da economia política no quadro das ciências sociais e a consequente independência da disciplina e a formação das Faculdades de Economia.

O trabalho de Paul Hugon tem grande mérito por seu pioneirismo e por apontar caminhos importantes, e, por isso mesmo, é citado por quase todos os estudiosos sobre o Pensamento Econômico Brasileiro. Notemos aqui que o critério de seleção de pensadores adotado pelo autor está 
diretamente ligado à introdução, difusão e o ensino de economia no país. Convém recorrer ao contexto histórico para entender que Paul Hugon fez parte do processo de constituição da Universidade de São Paulo. De origem francesa, assim como diversos outros professores, que na USP trabalharam (como Fernand Braudel, François Perroux e Michel Foucault), Hugon era responsável pela cátedra de Economia Política e História das Doutrinas Econômicas na FFCL e participou ativamente da criação de um instituto na USP que se dedicasse exclusivamente ao ensino e pesquisa de economia, hoje representado pela FEA. Ou seja, o autor está diretamente ligado à questão do ensino de economia, da criação de um dos cursos de economia mais tradicionais do Brasil e do desenvolvimento de uma das mais importantes Universidades do país ${ }^{76}$.

Merecem destaque também os trabalhos de Heitor Ferreira Lima77. No livro História do Pensamento Econômico no Brasil, o autor procura abordar o tema fazendo uma reflexão inicial sobre as doutrinas econômicas e o pensamento econômico em Portugal. Para ele, houve certo atraso dos estudos econômicos no país, o que seria um reflexo do seu atraso econômico, resultado da dependência da economia colonial, do comércio exterior, que levou a uma estagnação da estrutura econômica, principalmente no campo, e um atraso em relação aos outros países europeus. Lima aponta também a influência dos jesuítas em Portugal, como causa para o atraso nas reflexões filosóficas. Isso porque eles fecharam o país à renovação científica, processada pelo renascimento em toda a Europa. Este atraso na evolução econômica e no pensamento econômico em Portugal refletiria de forma importante no Brasil.

Em seguida, Lima apresenta os que, para ele, foram os primeiros economistas brasileiros. Analisando o período colonial, o autor procura argumentar que o predomínio quase que total da economia agrícola, da produção a partir do uso da terra, deram uma característica fisiocrática

\footnotetext{
${ }^{76}$ Ver PINHO, Diva Benevides. Economia política e a História das doutrinas econômicas. Estudos Avançados. vol.8 no.22 São Paulo Sept./Dec. 1994.

77 LIMA, Heitor Ferreira. História do Pensamento Econômico no Brasil. São Paulo: Cia. Editora Nacional, 1976.
} 
ao pensamento que se desenvolveu naquela época. Assim, apresenta figuras com Azeredo Coutinho, Manuel de Arruda Câmara, Manuel Ferreira da Câmara Bittencourt e Sá, José Bonifácio de Andrada e Silva e André João Antonil. Comum à maioria deles o fato de estudarem em Portugal, a ligação com a escola fisiocrática lusitana, e o fato de terem vivido em um momento de consolidação da economia brasileira, o que permitiu o enraizamento da população. Isso, para o autor, fortaleceria o sentimento nacional no Brasil e conduziria muitos deles a estudar e pensar os problemas técnicos e econômicos brasileiros. Aos poucos, esse sentimento nacional e a luta pelos interesses internos inaugurariam uma nova fase do pensamento econômico, "de profunda repercussão e de feições políticas e sociais, que acabaram desembocando na Independência, ou seja, na separação definitiva das duas nações" (LIMA, 1976, p.69).

A seguir, o autor destaca a luta pela autonomia do Brasil. Relata a importância das transformações mundiais entre o final do século XVIII e início do XIX, as revoluções burguesas na Europa, a revolução industrial, a independência americana, o nascimento da Economia Política com Smith e Ricardo na Inglaterra e a fisiocracia francesa. No Brasil, esse período se caracteriza pelo fim do regime colonial, nas palavras do autor, "no sentido do esgotamento de sua capacidade criadora". Os movimentos questionadores da dominação política emergiam como consequência do desenvolvimento da colônia. Assim:

\begin{abstract}
"À proporção que a situação da colônia se modificava completamente, em consequência do desenvolvimento que nela de operava, sua relação com a metrópole começava a se alterar, provocando mudanças de importância no pensamento econômico, dando-lhe um dinamismo que antes não possuía." (LIMA, 1976, p.72)
\end{abstract}

Dentre esses movimentos, o autor destaca a Inconfidência Mineira. Além disso, dá destaque à influência inglesa nas ideias nacionais e, logo, a busca pela defesa de atividades manufatureiras. A transferência da corte para o país em 1808 é mais um episódio da crise do sistema colonial, da emergência e do crescimento do Brasil, que irão desaguar na 
Independência. "Fortaleciam-se as classes comercial, burocrática e intelectual, dando lugar a outras elites sociais e econômicas, propiciando o surgimento de novos dirigentes para o país, completando-se assim a emancipação nacional" (LIMA, 1976, p.76).

Ademais, o autor destaca a figura do Visconde Cairu. Concordando, citando e levantando as mesmas ideias de Paul Hugon, Heitor Ferreira Lima, apresenta Cairu como um pensador original, que retratou o Brasil a partir das suas especificidades, difundindo as ideias de Adam Smith, defendendo o liberalismo, mas os condicionando aos interesses nacionais, portanto, nacionalista.

A partir daí, Heitor Ferreira Lima procura analisar a nova classe formada no Brasil que irá participar da Independência e comandará a nação a partir daí. Formada, em sua grande maioria, em Coimbra, tinha ideias liberais. Esse liberalismo se explicava pela conjuntura internacional, com os progressos nas ciências, a mundialização dos mercados, a defesa inglesa do livre mercado para seus produtos manufaturados.

Contudo, a apropriação do liberalismo no Brasil teve suas incoerências e peculiaridades. Se na Europa a ideologia liberal justificou e embasou revoluções democrático-burguesas, na América Latina serviu para justificar a independência política. No Brasil, o liberalismo foi a ideologia dos comerciantes, latifundiários e escravistas. Há uma profunda incoerência de princípios. Na Europa, a luta da burguesia contra a nobreza feudal, pelo industrialismo, no Brasil a luta é dos latifundiários e escravistas contra a opressão da metrópole, pelo livre comércio.

Ë justamente no entorno destas questões que se desenvolverá o debate econômico durante o primeiro reinado, para Heitor Ferreira Lima. Explorando os debates parlamentares e os discursos de importantes personalidades políticas da época, como Clemente Pereira, Campos Vergueiro, Bernardo Pereira de Vasconcelos e Lino Coutinho. Muitos deles ocuparam o ministério da Fazenda e suas ideias caracterizavam as visões econômicas dominantes naquele momento. A maioria deles defendia o livre-cambismo, a exportação de nossos produtos agrícolas e a importação 
de produtos manufaturados. Ou seja, "defendeu abertamente fazendeiros exportadores de gêneros agrícolas e o grande comércio importador de produtos industrializados, isto é, defendeu interesses das duas classes de maior peso em nossa economia e as de maiores atividades". (LIMA, 1976: p.89)

Já a indústria não merecia muitas atenções governamentais. Não havia interesse pelo seu progresso. O interesse ligado à terra e ao comércio, somado à ideologia liberal de especialização produtiva, sepultava qualquer interesse ligado ao desenvolvimento da indústria. Para Lima, enquanto os Estados Unidos ampliavam suas fronteiras, conquistavam territórios, dividindo as terras, criando pequenas propriedades agrícolas e assim fomentando o nascimento e o crescimento contínuo de um mercado interno, em que se beneficiava a imigração e fomentava o surgimento de indústrias, o Brasil ia pelo caminho do latifúndio e dos interesses das poucas classes dominantes.

O livro de Heitor Ferreira Lima é muito interessante e lança questões importantes sobre a formação nacional. Após apresentar o debate econômico durante o primeiro reinado, o autor irá discutir as ideias econômicas durante o segundo reinado e o final do século XIX, dando ênfase ao debate entre metalistas e papelistas, às crises econômicas do segundo reinado, ao pensamento de figuras importantes como Mauá, Ruy Barbosa, Joaquim Murtinho e Roberto Simonsen. Mais à frente, discutiremos mais aprofundadamente estas ideias e pensadores. Alguns deles foram retratados pelo próprio autor em outro livro importante ${ }^{78}$.

Por enquanto, é importante para nós ressaltar pontos importantes do trabalho de Heitor Ferreira Lima. Primeiramente, cabe ressaltar a opção metodológica do autor que não reduziu a História do Pensamento Econômico à simples apresentação de ideias de pensadores que ele considera mais importantes. Ao contrário, o autor buscou um trabalho de síntese, onde intercala a história dos acontecimentos com a história das

\footnotetext{
78 LIMA, Heitor, Ferreira. 3 Industrialistas brasileiros: Mauá, Rui Barbosa, Roberto Simonsen. São Paulo: Alfa-Omega, 1976.
} 
ideias e a relação entre elas. Ademais, cabe ressaltar a sua escolha por retratar o pensamento econômico no Brasil desde os tempos coloniais e, como esse período, assim como as raízes portuguesas, influenciaram na formação das ideias econômicas no Brasil. Mais ainda, cabe observar o critério de escolha dos pensadores e figuras mais importantes a serem retratados: quase todos são homens da política, ligados ao poder, aos governos. Mais do que isso, eles se apropriam das teorias econômicas sempre a partir dos interesses que os movem. Sejam eles interesses ligados às peculiaridades brasileiras, sejam eles ligados aos interesses das elites brasileiras. Assim, o pensamento econômico no Brasil surge para dar sentido e justificar as ações políticas. Posteriormente, abordaremos mais a questão.

Outro trabalho importante e que segue a mesma linha de Paul Hugon é o de Dorival Teixeira Vieira ${ }^{79}$, A História da Ciência Econômica no Brasil $^{80}$. Neste texto, o autor discute a formação do Pensamento Econômico Brasileiro, apresentando as principais influências a partir do ensino de Economia, primeiro nas Faculdades de Direito e Engenharia e, posteriormente, nas Ciências Sociais, e depois, com a formação dos cursos de Economia, nas Faculdades e Departamentos de Economia. Interessante, na análise, é perceber como a disciplina se desenvolveu no país. Um dos argumentos é que por ter se desenvolvido em Faculdades de Direito e Engenharia, teve sempre um caráter mais doutrinário, voltado à ação, às medidas políticas e ao desenvolvimento dos problemas econômicos nacionais. Assim, no Brasil, "não havia o ensino de Ciência Econômica, mas sim de Doutrinas Econômicas, mais ao sabor dos individualismos e das polêmicas, tão do grado da cultura brasileira durante os séculos XIX e XX". (VIEIRA, 1981, p.355)

\footnotetext{
${ }^{79}$ Dorival Teixeira Vieira foi um dos primeiros assistentes de Paul Hugon na cadeira de Economia Política e História das Doutrinas Econômicas na criação da Faculdade de Economia na USP. Ver PINHO, Diva Benevides, Op. Cit.

${ }^{80}$ VIEIRA, Dorival Teixeira. A História da Ciência Econômica no Brasil. In: FERRI, Mário Guimarães; MOTOYAMA, Shozo. (coordenadores). História das Ciências no Brasil. São Paulo: EPU: Edusp, 1979-1981.
} 
Mais recentemente, a tese de Amaury Gremaud ${ }^{81}$ aponta, inicialmente, a relação estabelecida por vários economistas entre os problemas relacionados ao desenvolvimento econômico tardio brasileiro, ou seu subdesenvolvimento, e a ausência de um pensamento econômico concreto, que refletisse a realidade brasileira durante o século XIX. Gremaud argumenta que, para autores como Furtado e Peláez, as concepções econômicas no Brasil do XIX estariam muito vinculadas à teoria econômica concebida a partir das economias desenvolvidas. Por isso, careciam de originalidade e não foram capazes de transformar a realidade brasileira. Gremaud aponta que, mesmo partindo do pensamento econômico produzido a partir da tradição europeia, existia alguma originalidade no Pensamento Econômico Brasileiro em termos das reflexões a respeito da nossa realidade e da forma como se adaptava tal tradição ao cenário brasileiro.

Baseado em Hugon, Gremaud concentra sua análise na discussão da entrada e difusão da economia política no Brasil durante o século XIX. Seu objetivo parece ser mostrar como e de que forma a Economia Política chegou ao Brasil, como se iniciou e de que maneira se materializou o ensino de Economia Política no país, que preparava e formava a intelectualidade brasileira que, em algum momento, seria responsável pela formulação da política econômica nacional. "Assim busca-se apreender que tipo de concepção de Economia Política e, dentro desta, de teoria monetária, fazia parte da formação acadêmica dos futuros formuladores da política econômica nacional." (GREMAUD, 1997, p.7)

O autor argumenta que estudar o Pensamento Econômico Brasileiro durante o século XIX é razoável, uma vez que a elite nacional se formou intelectualmente tendo contato com Economia Política e seus teóricos, sendo que tal formação teve influência no debate e na formulação da política econômica durante o período imperial. Seguindo uma estrutura semelhante à de Paul Hugon, apresenta o ensino de economia política nas

81 GREMAUD, Amaury. P. Das controvérsias teóricas à política econômica. Tese de doutorado. Universidade de São Paulo. 1997. 
Faculdades de Direito e Engenharia brasileiras durante o século XIX, a partir de um exaustivo levantamento bibliográfico de trabalhos a respeito do tema, bem como das obras adotadas nos cursos e das ideias defendidas pelos professores. De modo geral, procura quase sempre identificar ideias originais e interpretações específicas a respeito da realidade brasileira nos personagens e temas que apresenta. Desta forma, destaca o poder de apropriação e adaptação da teoria econômica tradicional pelos catedráticos brasileiros do século XIX.

Ao analisar o Pensamento Econômico Brasileiro a partir do ângulo do ensino de economia política, autores como Hugon e Gremaud evidenciam a originalidade de várias ideias concebidas no país. Por outro lado, destacam também o sentido prático que vários catedráticos davam às ideias econômicas. A análise do ensino de economia política no Brasil durante o século XIX consegue fornecer um retrato importante do Pensamento Econômico Brasileiro no período, isto é, um pensamento econômico que procurou sempre adaptar teorias econômicas dos países centrais. Conservadora ou progressista, poderíamos afirmar que tais adaptações não deixam de ser originais, afinal refletiam sobre a realidade brasileira.

Em síntese, pensar a história do pensamento econômico brasileiro é, antes de tudo, pensar as ideias que aqui foram produzidas a partir de reflexões sobre a economia e a realidade brasileira. Deste modo, são possíveis diversos critérios de seleção e determinação de pensadores e ideias a serem consideradas. De um lado, podemos entender que o Pensamento Econômico Brasileiro foi, desde o seu início, menos acadêmico e mais prático e, assim, analisar a influência de algumas personalidades que pensaram a economia brasileira sobre a política econômica concreta. Por outro lado, pode-se refletir como a teoria econômica se difundiu pelo país e influenciou a política econômica e o ensino de economia ou buscar ideias e teorias originais surgidos a partir do Brasil. 
Assim, é preciso sempre reafirmar a necessidade da discussão metodológica entorno da História do Pensamento Econômico. Ao final desta breve reflexão podemos reforçar a ideia de que é preciso e necessário considerar o pensamento e a teoria econômica de maneira ampla, reconhecendo a relação das ideias com o contexto e a realidade histórica em que estão inseridas. Deste modo, a reflexão sobre a História do Pensamento Econômico no Brasil não pode, nem deve, ser feita distante da reflexão histórica, o que dá a ela sentido e importância.

O conjunto dos trabalhos acima mostra que havia não só um pensamento econômico no Brasil, no sentido da difusão das ideias econômicas, como um Pensamento Econômico Brasileiro, no sentido da adaptação original. A reflexão a respeito da gênese do Pensamento Econômico Brasileiro no século XIX impõe ao historiador a necessidade de uma periodização e definição de critérios para a abordagem a respeito do tema.

Portanto, acreditamos ser possível não só falar em pensamento econômico brasileiro no século XIX, bem como organizar a questão a partir de uma vasta bibliografia, que, reunida, nos permite falar em um conjunto de trabalhos, uma historiografia sobre o tema. Alguns destes trabalhos foram brevemente discutidos neste capítulo como forma de ilustrar a questão metodológica.

No próximo capítulo trataremos de discutir detalhadamente os trabalhos sobre o tema, organizando-os e sintetizando de forma a caracterizar o que estamos definindo ao longo desta tese como pensamento econômico brasileiro no século XIX. 


\section{Capítulo 3}

\section{O Pensamento Econômico Brasileiro no século XIX: teoria e expressão prática}

Discutimos no capítulo anterior sobre a dificuldade de se refletir a respeito da História do Pensamento Econômico no Brasil. Trata-se de um desafio metodológico e teórico. Mas como podemos pensar o tema no país durante o século XIX?

Alguns temas possuem referências obrigatórias, o Pensamento Econômico Brasileiro não é diferente. De mesmo nome, o livro de Ricardo Bielschowsky se enquadra neste caso. Qualquer pesquisador ou estudo que pretenda se debruçar sobre o tema necessariamente irá recorrer a esta obra clássica.

O recorte temporal e metodológico do autor é bem claro, trabalhando com um referencial teórico baseado em Schumpeter, Bielschowsky argumenta que, na ausência e impossibilidade de uma discussão a respeito da História do Pensamento Econômico Brasileiro (ou da História da Análise Econômica Brasileira, para usar os termos de Schumpeter), nos resta analisar o que ele qualifica, nos termos schumpeterianos, Pensamento Econômico Brasileiro. Este seria composto e marcado pelo viés prático, pela política econômica com fim específico. $\mathrm{Na}$ visão do autor, as necessidades de transformação da realidade, no Brasil, impunham uma discussão pouco teórica, mais voltada para a ação. Desta forma, e partindo disto, o autor define o fim específico das políticas e da prática econômica, bem como periodiza sua análise e seleciona os personagens de seu trabalho. Assim, Bielschowsky analisa e discute a industrialização e o desenvolvimentismo na visão de algumas correntes de pensamento que ele mesmo estabelece, a partir de sua definição de desenvolvimentismo, entre 1930 e 1964. 
Não é nosso objetivo aqui discutir a metodologia de Bielschowsky, muito menos discutir seu critério para seleção de personagens ou sua definição de desenvolvimentismo e das correntes de pensamento. Este ponto já foi explorado no capítulo anterior. Um fato nos chama atenção não só no seminal estudo de Bielschowsky, mas em grande parte dos trabalhos sobre Pensamento Econômico Brasileiro. A grande maioria se concentra apenas no século XX. Não que autores como Bielschowsky ignorem o que aconteceu em períodos anteriores, pois, diante de seu tema, o desenvolvimentismo e a industrialização, seu recorte temporal é óbvio. Contudo, há uma observação necessária: a grande maioria dos trabalhos se concentra no século $X X$ pois define industrialização $e$ desenvolvimento como temas relevantes e pesquisáveis, dessa forma, ignoram indiretamente a possibilidade de um pensamento econômico brasileiro em períodos anteriores. Aqui, estamos nos referindo nitidamente ao século XIX e a todas as possibilidades de estudo e pesquisa que este período representa como tema para a História do Pensamento Econômico.

Não é nenhum absurdo estudar o Pensamento Econômico Brasileiro no século XIX. Este parece, contudo, um assunto que pouco interessa aos economistas. Não é por outra razão que grande parte dos estudos pertence aos historiadores. De certa forma, é como se o tema não dissesse respeito aos economistas ou mesmo não lhes fosse relevante. Discordamos dessa ideia, assim, reconhecemos a importância e a centralidade das questões relativas à industrialização e ao desenvolvimento como fundadores de um pensamento econômico nacional, centrado em figuras essenciais como as de Celso Furtado, Roberto Simonsen, Caio Prado Junior, Ignácio Rangel, Rômulo Almeida, entre outros. Devemos reconhecer, no entanto, a importância de resgatar as ideias e o Pensamento Econômico Brasileiro no século XIX como uma forma não só de melhor compreender nossa história econômica e social, mas também como uma possibilidade de melhor compreender nossa formação cultural e de identidade. 
Não que concordemos com a metodologia de Bielschowsky, e isso deixamos claro no capítulo anterior, mas, da mesma forma que o autor organizou correntes e estudou o pensamento nacional a partir da compreensão que este era mais prático que teórico e, por isso mesmo, adaptava teorias importadas com finalidades práticas específicas entre 1930 e 1964, por que não abordar e estudar a questão sob a mesma abordagem a partir da prática e dos debates em tornos dos temas econômicos durante o século XIX?

Amaury Gremaud $^{82}$ argumenta que, de certa forma, vários economistas consideram que um dos problemas relacionados ao desenvolvimento econômico tardio brasileiro, ou seu subdesenvolvimento, estaria relacionado à ausência de um pensamento econômico concreto, que refletisse sobre a realidade brasileira durante o século XIX. Assim, para autores como Furtado e Peláez, as concepções econômicas no Brasil do séc. XIX estariam muito presas ao pensamento econômico produzido em economias desenvolvidas.

No clássico Formação Econômica do Brasil, Celso Furtado ${ }^{83}$ afirma por exemplo que:

"Ao historiador, das ideias econômicas no Brasil não
deixará de surpreender a monótona insistência com que
se acoima de aberrativo e anormal tudo que ocorre no
país: a inconversibilidade, os déficits, as emissões de
papel-moeda. Essa "anormalidade" secular não chega,
entretanto, a constituir objeto de estudo sistemático.
Com efeito, não se faz nenhum esforço sério para
compreender tal anormalidade, que em última instância
era a realidade dentro da qual se vivia. Todos os
esforços se gastam numa tarefa que a experiência
histórica demonstrava ser vã: submeter o sistema
econômico às regras monetárias que prevaleciam na
Europa. Esse enorme esforço de mimetismo - que

82 GREMAUD, Amaury Patrick. Das Controvérsias Teóricas à Política Econômica: pensamento econômico e economia brasileira no segundo império e na primeira república (1840-1930). Tese (Doutorado em Economia) - Universidade de São Paulo, 1997.

83 FURTADO, Celso. Formação Econômica do Brasil. São Paulo: Companhia das Letras, 2009. 
derivava de uma fé inabalável nos princípios de uma doutrina sem fundamento na observação da realidade se estenderá pelos três primeiros decênios do século XX". (FURTADO, 2009, p. 163-164)

Deste modo, para Celso Furtado, "o político brasileiro, com formação de economista" se encontrava preso às teorias econômicas europeias e procurava submeter à economia brasileira as regras monetárias derivadas de tais teorias sem qualquer preocupação com a especificidade da realidade nacional. Isso, em sua visão, fazia com que a questão não se tornasse objeto de estudo para a História do Pensamento Econômico Brasileiro. Questão semelhante fica clara quando Furtado confronta o desenvolvimento brasileiro ao dos Estados Unidos e aponta José da Silva Lisboa, o Visconde de Cairu, como mero reprodutor das ideias de Adam Smith e das doutrinas liberais. Ponto que exploraremos com maior rigor mais à frente.

Carlos Manuel Pelaez ${ }^{84}$, sob outra perspectiva, acredita que a incapacidade do país de superar os seus problemas econômicos no período anterior à Segunda Guerra teria sido resultado da falta de economistas preparados para lidar com a questão. Para o autor, tal questão se remete à adoção de políticas econômicas baseadas nas doutrinas da escola da ortodoxia monetária, adotadas por políticos, advogados e comerciantes com pouco conhecimento da teoria econômica.

Portanto, como bem mostra Gremaud, para Pelaez, a política econômica carecia de originalidade e não foi capaz de transformar a realidade brasileira. Isto seria resultado da ausência de instituições formadoras de economistas com saber técnico bem definido, especificamente preparados para a realidade com as especificidades e os problemas decorrentes da economia brasileira. Essa questão é interessante e coloca vários problemas:

\footnotetext{
${ }^{84}$ PELAEZ, Carlos Manuel. As Consequências Econômicas da Ortodoxia Monetária, Cambial e Fiscal no Brasil entre 1889-1945. Revista Brasileira de Economia. Rio de Janeiro, 25 (3):5/82, jul./set. 1971 e PELAEZ, Carlos Manuel; SUZIGAN, Wilson. História Monetária do Brasil. Brasília: Editora Universidade de Brasília, 1981.
} 
Primeiro: o que é um economista com saber técnico bem definido e especificamente preparado? Será que faz sentido pensar assim em meados do século XIX e no início do século XX, não só no Brasil, como no mundo todo? Será que seria possível formar economistas técnicos naquele momento? Será que seria possível haver instituições para isso? Pensar assim não exclui o fato de que a forma de se fazer economia no Brasil, durante o século XIX e o início do XX, qual seja, reproduzir de alguma forma as ideias produzidas nos países centrais, não teria um sentido para quem as produzia? Um sentido político (é coerente excluir a política da análise?), logo, um conservadorismo intencional? Não faria mais sentido analisar as ideias produzidas durante o século XIX e tentar entender de que forma elas reproduziram as ideias importadas e qual o sentido político e prático disso? Mais do que isso, será que o simples fato de haver um tipo de reprodução de um pensamento econômico importado de outros lugares já não caracteriza um pensamento econômico nacional e, por isso, faz muito sentido entendê-lo a partir de suas especificidades e formas de apropriação?

Nas palavras de Gremaud,

\begin{abstract}
"Mesmo partindo de matrizes teóricas europeias, existe alguma originalidade no pensamento econômico brasileiro, se não no sentido de formular novos avanços teóricos, pelo menos em termos de reflexões sobre a nossa realidade e da adequação destas teorias a ela. Além do que, esta realidade era ponto importante na escolha feita pelos analistas nacionais dentro do leque de possibilidades teóricas apresentado pela Economia Política dos países centrais. Mesmo porque as pessoas envolvidas reconheciam os efeitos distributivos envolvidos na adoção das medidas preconizadas pelas diferentes teorias. É justamente a partir destes efeitos que se delineiam as alianças entre os diferentes grupos no que concerte à determinação da política econômica ao longo deste período. Novamente, pode-se até não concordar com as análises ou as adaptações das teorias à realidade nacional feitas quando da determinação da política econômica, porém não foi a falta delas que
\end{abstract}


marcou política econômica no Segundo Reinado e da Primeira República". (GREMAUD, 1997:3-4)

Evidentemente é preciso entender os objetivos de Furtado e Pelaez em seus trabalhos. Enquanto, para o primeiro, a preocupação central seria entender quais as condições objetivas para a industrialização e para a superação do subdesenvolvimento, o segundo procura entender o impacto da política monetária sobre a economia brasileira. Contudo, tanto um quanto o outro ilustram como as discussões sobre Pensamento Econômico Brasileiro sempre tiveram um enfoque nas questões relativas ao desenvolvimento e a industrialização e, assim, por consequência, no século XX. Todas as outras questões e períodos foram menos estudados e tiveram menor atenção, sobretudo dos economistas.

Geraldo Beauclair ${ }^{85}$ também aborda tal questão, como aliás já observamos no capítulo anterior. Para o autor, o século XIX é esquecido pelos economistas do ponto de vista da História do Pensamento Econômico, uma vez que os pensadores dos oitocentos não teriam muito a contribuir com as discussões a respeito do desenvolvimento econômico. Tal esquecimento, para Beauclair, prejudica a compreensão da realidade brasileira, uma vez que o pensamento do século XIX teria muito a contribuir não só com as questões relativas ao desenvolvimento econômico, bem como com a construção do que ele denomina como "Economia Nacional".

Defendemos, neste trabalho, a ideia de que é preciso e possível refletir sobre como se deu o pensamento econômico no Brasil durante o século XIX, como se pensou a realidade econômica nacional, como se apropriou das teorias produzidas nos países centrais e quais eram os interesses envolvidos nisso.

\footnotetext{
${ }^{85}$ BEAUCLAIR, Geraldo. M. O. A construção inacabada: a economia brasileira (1820-
} 1860). Rio de Janeiro: Vício de leitura, 2001. 


\section{Ponto de partida}

Abordar o século XIX no Brasil como objeto de análise a partir da lógica do pensamento econômico, entretanto, não resolve por completo o problema de periodização que todo estudo historiográfico enfrenta. Dito de maneira mais clara: por onde devemos começar, quais autores devemos abordar? Esta é uma questão difícil de ser respondida.

Geraldo Beauclair argumenta que existiriam duas maneiras de se abordar o Pensamento Econômico Brasileiro no século XIX. De um lado, uma abordagem ligada a uma matriz teórica tradicional ou vinculada ao mainstream econômico, analisando a influência da teoria econômica, concebida na Europa, nas ideias e interpretações da realidade brasileira. Para o autor, isto caracterizaria uma espécie de "Evolução da Teoria Econômica no Brasil". De outro, poderia se analisar personagens que, à margem da teoria tradicional ou sem as matrizes teóricas tradicionais, interpretaram a realidade econômica brasileira a partir de sua realidade e das suas próprias especificidades. Para Beauclair, para se realizar uma História do Pensamento Econômico Brasileiro era preciso encarar e levar em conta esta segunda possibilidade. É o que o autor faz em seu trabalho, analisando o que ele caracteriza de construção da Economia Nacional, ou de uma Economia Política Nacional, a partir das preocupações de certos segmentos da sociedade brasileira do período que o autor caracteriza como pré-industrial. Tais preocupações refletiriam os interesses destes setores, bem como o estágio da Economia Brasileira na primeira metade do século XIX; e estariam expressos em publicações da Sociedade Auxiliadora da Indústria Nacional, nos papeis do Museu Nacional, em relatórios oficiais e nas Juntas de Comércio, Indústria e Navegação.

"O pensamento econômico brasileiro da primeira metade do século XIX, sem 'matrizes', de um estágio pré-industrial, refletiu as preocupações de certos segmentos da sociedade nacional e percebeu as características daquele estágio: predomínio da agricultura, ritmo lento e espasmódico de crescimento, 
que às vezes pode ser bruscamente reversível, carência de inter-relacionamento tecnológico (ou desníveis técnicos acentuados em ramos da produção) e incapacidade dos bancos de proverem as necessidades do setor de transformação de bens, o que era feito diretamente pelo Estado". (BEAUCLAIR, 2001, p. 219220)

Para o autor, estes personagens e estas ideias ficaram relegadas na historiografia brasileira, sobretudo porque tais reflexões nunca estiveram publicadas sistematicamente em formato de livros ou compilações, como no caso de pensadores como Azeredo Coutinho ou o Visconde de Cairu.

Concretamente, acreditamos que esta abordagem abre espaço para inúmeras possibilidades. A partir de tal lógica, poderíamos considerar que o pensamento econômico brasileiro consistiria em toda e qualquer interpretação da realidade brasileira que levasse em conta aspectos econômicos. Proposta parecida tem sido levada a cabo por pesquisadores comandados por Maria Malta. ${ }^{86}$, contudo, apesar de importante e interessante, a proposta de Beauclair ignora o fato de que, grande parte do pensamento econômico brasileiro, seja ele resultado de uma adaptação de uma matriz teórica tradicional ou uma interpretação original da realidade brasileira, sempre teve bastante conteúdo prático. Formulações teóricas formalizadas e publicadas em livros ou compilações não nos parecem ser uma característica fundamental do Pensamento Econômico Brasileiro, mesmo no século XX, como bem mostra Ricardo Bielschowsky. No que diz respeito ao século XIX, também não podemos ignorar que 0 pensamento econômico sempre teve um conteúdo pratico muito forte, mesmo nas ideias de José da Silva Lisboa, ou de maneira mais clara quando discutimos o ensino de Economia Política ou no rico e extenso debate monetário durante o Império.

Além disso, não há como ignorar o fato de que, mesmo partindo de adaptações de teorias à realidade brasileira, muitas das reflexões

\footnotetext{
${ }^{86}$ MALTA, Maria; CURTY, Carla; BORJA, Bruno. Intérpretes do Brasil: influências na origem do pensamento econômico brasileiro. In: Anais XVI Seminário sobre a economia mineira, CEDEPLAR-UFMG, Diamantina, 2014.
} 
econômicas no país, durante o período oitocentista, têm sua originalidade como resultado da sobreposição da realidade sobre a teoria. Aliás, o próprio Beauclair levanta tal questão, sobretudo ao valorizar as contribuições do Visconde de Cairu; tal discussão, no entanto, não resolve o problema circunscrito na questão, logo, por onde começamos?

Quando falamos em século XIX, no Brasil, um ponto de referência nos parece obrigatório: o ano de 1808, em que a corte portuguesa desembarcou no país e uma série de mudanças e desdobramentos acabaram por resultar no processo de Independência em 1822. Evidentemente, o que estamos considerando aqui é a referência de um processo de transformação da realidade luso-brasileira que se reflete em uma série de medidas e mudanças da realidade, bem como do cenário da crise da economia e do sistema colonial, também da crise do mundo mercantil em Portugal e a emergência de uma nova realidade política e econômica. ${ }^{87}$

Dessa forma, optamos por iniciar a nossa discussão a partir de José da Silva Lisboa, o Visconde de Cairu. Evidentemente, não ignoramos a importância das ideias de José Joaquim da Cunha Azeredo Coutinho ${ }^{88}$, por exemplo, contudo, acreditamos que Cairu reflete bem este mundo em transformação, bem como a emergência do Brasil como nação independente ${ }^{89}$. Armando de Castro $^{90}$ traduz bem a questão,

\footnotetext{
${ }^{87}$ Ver por exemplo ARRUDA, José Jobson, O sentido da Colônia: revisitando a crise do antigo sistema colonial no Brasil (1780-1830). In: TENGARRINHA, José (Org.). História de Portugal. Bauru: Edusc, 2000; ARRUDA, José Jobson. Uma colônia entre dois impérios: a abertura dos portos brasileiros 1800-1808. Bauru: Ed. Edusc, 2008; NOVAIS, Fernando A. Portugal e Brasil na crise do antigo sistema colonial. São Paulo: Hucitec, 1979.

${ }^{88}$ Ver CANTARINO, Nelson Mendes. A razão e ordem: o Bispo José Joaquim da Cunha de Azeredo Coutinho e a defesa ilustrada do Antigo Regime português (1742-1821). Tese de Doutorado. Universidade de São Paulo, 2012; CANTARINO, Nelson Mendes. Conjugando tradições: o pensamento econômico do bispo Azeredo Coutinho entre a herança ibérica e as ideias ilustradas setecentistas (1791-1816). Revista História Econômica \& História de Empresas, v.15, n.2, 2012; AZEREDO COUTINHO, José J. C. Obras econômicas. São Paulo: Companhia Editora Nacional, 1966. Apresentação de Sérgio Buarque de Holanda. ${ }^{89}$ NOGUEIRA DE PAULA (1942) também ressalta esta diferença entre Azeredo Coutinho e Cairu. Enquanto o primeiro tem suas ideias vinculadas à realidade metrópole-colônia do
} 
"Querendo acentuar-se um dos traços mais significativos dos estudos económicos concretos do Visconde de Cairu destacar-se-ia o facto de serem guiados pelo objectivo de defender os interesses próprios da burguesia brasileira em luta contra a dominação colonial, ao contrário do que sucedeu com o seu compatriota e contemporâneo José J. da Cunha de Azeredo Coutinho, apenas uns 13 ou 14 anos mais velho do que ele". (CASTRO, 1980, p. 71)

\section{José da Silva Lisboa, o Visconde de Cairu}

Cairu merece um lugar de destaque quando abordamos o Pensamento Econômico Brasileiro. Se, por um lado, não são tão numerosos os trabalhos a seu respeito e às suas ideias quanto o valor de sua obra nos permitiria supor, por outro, com alguma certeza, podemos afirmar que ele é o autor/pensador brasileiro mais estudado do século XIX. Tal questão é bem ilustrativa de como o Pensamento Econômico Brasileiro oitocentista tem pouca atenção de pesquisadores e estudiosos, principalmente entre os economistas.

Tal questão nos remete novamente a Celso Furtado e seu magnífico Formação Econômica do Brasil, precisamente ao capítulo XVIII, quando confronta o desenvolvimento brasileiro ao dos Estados Unidos e as ideias do Visconde de Cairu às de Alexander Hamilton ${ }^{91}$. Nas palavras e no julgamento impiedoso de Furtado, "Cairu crê supersticiosamente na mão invisível e repete: deixai fazer, deixai passar, deixai vender" (Furtado, 2009, p.165-166) Por si só o tom condenatório do maior entre todos os economistas brasileiros à Silva Lisboa parece ter lançado ao esquecimento e limitado o interesse entre os economistas de melhor explorar e conhecer

Império Português, o segundo tem sua produção intelectual intimamente relacionada à emergência do Brasil como nação.

${ }^{90}$ CASTRO, Armando de. O Pensamento Económico no Portugal Moderno. Biblioteca Breve, Vol. 48, Instituto de Cultura Portuguesa, 1980.

${ }^{91}$ FURTADO, Celso. Formação Econômica do Brasil. São Paulo: Companhia das Letras, 2009. 
a sua obra. A visão furtadiana de que Cairu em nada teria a contribuir com o debate sobre o desenvolvimento foi implacável.

Em tese defendida na década de 1970, Dea Fenelon também contrapôs Cairu e Hamilton a partir do estudo sistemático de suas ideias. Para a historiadora, ambos eram discípulos de Adam Smith e visavam a consolidação do Estado Nacional, sendo que o primeiro se apresentou como um defensor de um liberalismo contraditório, que justificava a escravidão e atendia aos interesses da elite formada pelos proprietários rurais, enquanto o segundo mostrou-se defensor da modernidade, da indústria e do impulso econômico americano.

Em trabalho clássico, José Honório Rodrigues o caracterizou como um mero bajulador. ${ }^{92}$ Não menos importante, também, foram as visões dos grandes Antonio Candido e Sérgio Buarque de Holanda. Para o primeiro, Cairu não passaria de "um palaciano de adulação", enquanto, para o segundo, não passaria de um mero repetidor de Adam Smtih, por vezes um tradutor que distorcia as palavras do mestre em nome dos interesses que pretendia provar e sendo por tudo isso "inatual" ou de contribuição "pouco fecunda". ${ }^{93}$

De certa forma, tais interpretações contribuíram para que o interesse sobre a obra de José de Silva Lisboa fosse menor que a magnitude de suas ideias.

Um trabalho mais contemporâneo é o de Antônio Penalves Rocha ${ }^{94}$; nele, o autor procura estudar o pensamento de Cairu a partir de uma

\footnotetext{
92 RODRIGUES, José Honório. História da História do Brasil. v. II, t. I. São Paulo: Companhia Editora Nacional, 1988.

${ }^{93}$ Ver CANDIDO, Antonio. Literatura e Sociedade. São Paulo: Publifolha, 2000; HOLANDA, Sérgio Buarque de. Raízes do Brasil. São Paulo: Cia das Letras, 1995; HOLANDA, Sérgio Buarque. Inatualidade de Cairu. In: Por uma nova história. São Paulo: Ed. Fundação Perseu Abramo, 2004.

${ }^{94}$ ROCHA, Antonio Penalves. A economia política na sociedade escravista. São Paulo: Hucitec, 1996; ROCHA, Antônio Penalves. Economia e política no período joanino. In: LAPA, José Roberto do Amaral e SZMRECSÁNYI, Támas. História econômica da Independência e do Império. São Paulo: Edusp, Hucitec, ABPHE, 1996; ROCHA, Antônio Penalves. Introdução. In: José da Silva Lisboa, visconde de Cairu. São Paulo: Ed. 34,
} 
perspectiva não condenatória, para tanto, reconhece a sua importância ao apresentá-lo como grande introdutor e difusor da Economia Política no Brasil. Assim, a partir da perspectiva da difusão das ideias econômicas, procura recuperar e valorizar trabalhos sobre o Pensamento Econômico Brasileiro no século XIX, mostrando como Cairu adaptou a Economia Política de Adam Smith à realidade escravista brasileira. Sua interpretação, entretanto, das ideias de Silva Lisboa não foge à perspectiva de enquadrá-lo como um burocrata a serviço da coroa portuguesa e brasileira.

Para Antonio Penalves Rocha, a obra de Cairu pode ser entendida como peça importante do processo de constituição do Estado nacional brasileiro. "Cairu compôs um conjunto lógico de ideias econômicas, cujo suporte foi dado pela Economia Política clássica. É este conjunto que será conectado com as mudanças políticas que ocorreram no Império português nos princípios do século XIX, levando à formação do Estado nacional brasileiro". (ROCHA, 1997, p.10)

Para o autor, Silva Lisboa foi o grande divulgador da Economia Política no Brasil e o fez sob a batuta e tutela do Estado, logo, "a ciência foi agregada ao Estado e, como é de se esperar, prestou serviços a ele." (ROCHA, 1997, p.39). Dito de outra forma, a Economia Política no Brasil foi uma ferramenta do poder do Estado, que dela se utilizou para justificar as suas atitudes. Silva Lisboa teve um importante papel, pois foi responsável pela divulgação oficial de tais ideias, ademais, sempre teve a preocupação de adaptá-las a realidade brasileira e aos objetivos monárquicos, bem como teve o papel de justificar as medidas e políticas estatais através da Economia Política. Além disso, cabe destacar que esta estava ligada à ideia de progresso e opulência universal da nação. Era, portanto, necessária para o progresso e desenvolvimento de qualquer país.

2001 e ROCHA, Antônio Penalves. A Economia Política no mundo português do início do século XIX. In: A recolonização do Brasil pelas cortes: histórias de uma invenção historiográfica. São Paulo: Ed. UNESP, 2009. 
Assim, para Rocha,

"o pensamento econômico de Silva Lisboa, bem como a memória de sua militância política, foram elevados à condição de modelos para a construção de uma nação que não desejava convulsões políticas e que apostava na ciência como um meio para atingir o progresso." (ROCHA, 1997, p.31)

As interpretações do pensamento e da obra de Cairu, no entanto, também apresentam uma vertente oposta, que procura valorizar a originalidade de seus escritos.

O início do texto de José de Almeida ${ }^{95}$ na apresentação de Estudos do Bem Comum e Economia Política ilustra bem esta perspectiva:

"José da Silva Lisboa foi o economista brasileiro mais original, mais fecundo e o único que, até agora, produziu uma obra que, pelos conceitos que encerra e pelas doutrinas que divulga, pode ser considerada verdadeiramente imortal. Tão imortal que, decorrido um século e meio, continua atual, jovem, indispensável." (ALMEIDA, 1975: p.3-4)

Para Almeida, Cairu, apesar de se definir como um "divulgador da ciência alheia", foi muito além, "definindo princípios, desenvolvendo ideias". Ideias que, para o autor, se preocupavam com a construção nacional e as bases do processo de desenvolvimento econômico, dando ênfase na questão da justiça social, bem como relacionando o processo de desenvolvimento à educação, ao emprego, à questão tecnológica e ao livre comércio. Surpreendentemente, José de Almeida chama a atenção também para a questão da distribuição de renda, ao afirmar que Cairu acreditava que "o desenvolvimento econômico era uma batalha contra a pobreza e as desigualdades" (Almeida, 1975, p.42). Além disso, reafirma a importação da agricultura para o processo de desenvolvimento, bem como declara que "Cairu demonstrava ter consciência da importância da

\footnotetext{
${ }^{95}$ ALMEIDA, José de. Atualidade das Ideias Econômicas do Visconde de Cairu. In: SILVA LISBOA, José. Estudos do Bem Comum e Economia Política. Rio de Janeiro: IPEA/INPES, 1975.
} 
substituição de importações como estratégia de industrialização". (ALMEIDA, 1975, p.45).

Evidentemente que é preciso relativizar a interpretação efusiva de José de Almeida que, anacronicamente, viu até práticas keynesianas na obra de Silva Lisboa. Desconte-se o fato que o texto foi escrito em um período no qual a questão da industrialização e participação do Estado neste processo eram elementos vivos da realidade econômica. O trabalho de Almeida tem o mérito inegável, para além dos exageros, de propor um Cairu como intérprete original.

Anteriormente, em texto publicado na edição dos Princípios de Economia Política, Alceu Amoroso Lima ${ }^{96}$ procura apresentar e valorizar as ideias de José da Silva Lisboa como pensador original. Já Nogueira de Paula97, na introdução dos mesmo Princípios, vai além da questão da originalidade e argumenta que Cairu teria influenciado ninguém menos que David Ricardo.

Em trabalho anterior, Luiz Nogueira de Paula ${ }^{98}$ argumenta que a obra de Silva Lisboa é uma obra de economia social e que seu sistema econômico se funda "no trabalho e na liberdade de comércio e de indústria, mas governados pela inteligência e justiça social" (NOGUEIRA DE PAULA, 1942, p.18).

Outro trabalho que apresenta Cairu como intérprete e pensador original, mas também se exalta e exagera na interpretação é o de Pinto de Aguiar; ${ }^{99}$ para ele, Cairu não seria um mero expositor de ideias, mas sim um "renovador, sendo na época um dos mais avançados comercialistas e economistas de todo mundo". (AGUIAR, 1960 p. 71) Analisando

\footnotetext{
96 LIMA, Alceu Amoroso. Época, vida e obra de Cairu. In: Silva Lisboa, José. Princípios de Economia Política. Rio de Janeiro: Ed. Irmãos Pongetti, 1956.

97 NOGUEIRA DE PAULA, Luiz. Introdução. In: SILVA LISBOA, José. Princípios de Economia Política. Rio de Janeiro: Ed. Irmãos Pongetti, 1956.

${ }^{98}$ NOGUEIRA DE PAULA, Luiz. Síntese da Evolução do Pensamento Econômico no Brasil. Rio de Janeiro: Serviço de Estatística da Previdência e Trabalhos, 1942.

${ }^{99}$ AGUIAR, Pinto de. A Abertura dos Portos - Cairu e os Ingleses. Salvador: Progresso Editora, 1960.
} 
especificamente a Abertura dos Portos, o autor procura discutir a importância e atuação de Silva Lisboa para o evento. Para ele,

"Cabe a Cairu, sem dúvida possível a suprema glória de ter capacitado, isto é, esclarecido o Príncipe, mostrando-lhe que os verdadeiros interesses da Realeza se confundiam com os interesses brasileiros, e que consonantes com as doutrinas avançadas da época, atendidos por uma série de atos coordenados e coerentes, tentariam criar na América um país florescente e progressista (...) ". (AGUIAR, 1960, p. 78)

Em Cairu e o liberalismo econômico, Antonio Paim ${ }^{100}$ procura situar Cairu a partir da Economia Política, procurando o que havia de específico em seu pensamento.

"José da Silva Lisboa foi o pensador brasileiro que procurou familiarizar-nos com as ideias da Economia Clássica, ao longo das três primeiras décadas do século passado. $\mathrm{E}$ o fez em duas frentes perfeitamente delineadas: publicando imensa obra de divulgação do liberalismo econômico, elaborada de modo regular e sistemático; e defendendo a liberdade de comércio que se estabelecera com a transferência da corte para o Brasil. Supunha que essa providência, complementada pelo aperfeiçoamento moral que adviria do conhecimento de suas bases teóricas, seria suficiente para encaminhar o Brasil na senda do progresso e da felicidade de seu povo, para inspirá-lo na adoção de medidas heroicas tornadas imprescindíveis, dentre as quais destacava a abolição do elemento servil". (PAIM, 2008, p.19)

Sendo um elemento central, para Paim a obra de Cairu tem um sentido claro, qual seja, a partir da divulgação e propagação da Economia Política e da contribuição do Liberalismo Econômico no Brasil para o progresso ou melhoramento material da nação. Tal perspectiva, para o autor, vai de encontro à percepção de Silva Lisboa do que seriam os princípios da Economia Política, isto é, o de conduzir a sociedade e o Estado à maior opulência possível.

100 PAIM, Antonio. Cairu e o Liberalismo Econômico. Assembleia Legislativa do Estado da Bahia, 2008. (1a. edição - pela Editora Tempo Brasileiro, 1968) 
Para Paim, a obra de Cairu precisa ser analisada a partir de seu sentido próprio, tendo como referência a época em que viveu. Sua Economia Política não pode ser descolada do contexto e de sua realidade, ou seja, de um período em que a elite luso-brasileira incorporava o pensamento moderno depois de ignorá-lo durante dois séculos. Período, portanto, complexo, peculiar e de transformações, uma vez que Portugal demorou a incorporar os valores do iluminismo e do liberalismo. Desta forma, apresenta José da Silva Lisboa como figura essencial neste processo de incorporação à elite luso-brasileira dos valores da modernidade.

Darcy de Carvalho ${ }^{101}$ também interpreta a obra de Cairu, valorizando sua originalidade e contribuição no campo do Pensamento Econômico Brasileiro, ao associar o livre comércio ou comércio franco e a liberdade econômica ou liberdade de indústria como elementos centrais do processo de desenvolvimento econômico. Assim o caracteriza:

"como um economista desenvolvimentista que via no livre-comércio (comércio franco) e na liberdade econômica (liberdade de indústria) os instrumentos providenciais para detonar o desenvolvimento econômico. Dadas estas duas pré-condições (comércio franco e liberdade da indústria) seguir-se-ia natural e paulatinamente o desenvolvimento da nação, o qual, iniciado, prosseguiria indefinidamente. $O$ autor entende o desenvolvimento como um processo de mudança cultural através do comércio. As variáveis limitantes são a população e a tecnologia." (CARVALHO, 1985, p.16)

Outro autor que valoriza as contribuições e originalidade de Cairu é Paul Hugon ${ }^{102}$, que procura mostrar a influência de Adam Smith em seu pensamento, argumentando que Silva Lisboa não era um simples vulgarizador das ideias de Adam Smith e refletiu sobre a economia política

\footnotetext{
101 CARVALHO, Darcy. Desenvolvimento e livre comércio: as ideias econômicas e sociais do Visconde de Cairu - um estudo de história do pensamento econômico brasileiro. São Paulo: IPE-USP, 1985.

102 HUGON, Paul. A Economia Política no Brasil. In: AZEVEDO, Fernando de (org.). As Ciências no Brasil. 2a Ed., V.2., Rio de Janeiro: Editora UFRJ, 1994.
} 
a partir da realidade nacional, ou seja, a partir da realidade brasileira, do seu passado colonial e da sua estrutura, evidentemente peculiar, se comparada com a Inglaterra de Smith. Desta forma, apresenta Cairu como um defensor da indústria e um liberal, mas, antes de tudo, um nacionalista, comercialista e industrialista, um defensor da construção de uma economia nacional que, na opinião do autor, adiantou o essencial das ideias de List no importante Sistema Nacional de Economia Política; em resumo, apresenta José da Silva Lisboa como responsável por elaborar uma doutrina especificamente brasileira:

"Existe, assim, nessa doutrina que nasce no Brasil nesse princípio de século, uma síntese de ideias tiradas do mercantilismo evoluído do fim do século XVIII e do liberalismo inglês, síntese realizada por Cairu exatamente no quadro das condições do meio brasileiro e de suas possibilidades de evolução." (HUGON, 1994, p.347)

Paul Hugon argumenta que a defesa que Cairu faz da medida de revogar a proibição de indústrias e manufaturas de $D$. João representaria uma nítida tendência industrialista de seus argumentos. De tal modo, para Hugon, Cairu antecipava List com argumentos nacionalistas de defesa da indústria nacional.

Heitor Ferreira Lima ${ }^{103}$ apresenta argumentos semelhantes ao apresentar Cairu como pensador original, que retratou o Brasil a partir da suas especificidades, difundindo as ideias de Adam Smith, defendendo o liberalismo, mas os condicionando aos interesses nacionais, portanto, nacionalista.

Já Amaury Gremaud ${ }^{104}$ relativiza o argumento de Hugon, porém, reafirma um caráter adaptativo e criativo das ideias de Cairu. Para o autor, a introdução da Economia Política no Brasil tinha dois sentidos básicos: Por um lado, assume o caráter de divulgação das ideias liberais

\footnotetext{
103 LIMA, Heitor Ferreira. História do pensamento econômico no Brasil. São Paulo: Cia Ed. Nacional, 1976.

${ }^{104}$ Gremaud, A. Op. Cit
} 
clássicas e, por outro, o pensamento que aqui se desenvolvia (e Cairu seria o grande exemplo) ganhava aspectos originais. Esta originalidade estaria na centralidade do comércio nas análises e na importância atribuída na intervenção do estado.

José Flávio Pereira, ${ }^{105}$ em sua tese de doutoramento, procura demonstrar certo caráter progressista na obra de Cairu ao analisar o seu pensamento reformador das instituições do Antigo Regime que caracterizavam o Império Português.

Já Carlos de Faria Junior ${ }^{106}$, também em tese defendida na USP, procura ressaltar a importância política, sobretudo nas questões econômicas, da obra de Silva Lisboa, sem enquadrá-lo como um simples defensor das políticas e dos interesses da coroa. Para tanto, analisa os elementos relativos à vinda e à presença da família real no Brasil, bem como a Abertura dos Portos em 1808, com especial atenção à Política Econômica e um dos seus principais formuladores, Cairu.

A originalidade de Cairu, seu valor como pensador econômico e como figura central na política econômica luso-brasileira, são destacados por Fernando Novais e José Jobson Arruda ${ }^{107}$, que procuram apresentá-lo articulando sua obra com o contexto histórico, portanto, comentando texto clássico de José da Silva Lisboa (Observações sobre a franqueza da indústria, e estabelecimento das fábricas no Brasil de 1810), o definem como produto de um contexto, o mundo luso-brasileiro no final do século XVIII e o primeiro quarto do século XIX, quando este começou a incorporar os valores do pensamento ilustrado; bem como pensador econômico original que se apropriou dos elementos da Economia Política e diante da vida econômica brasileira, os reescreveu a partir do que acreditava ser a necessidade prática de progresso da Nação.

105 PEREIRA, José Flávio. Cairu revisitado: uma contribuição ao estudo do reformismo liberal. Tese de Doutorado. História Social, FFLCH-USP, São Paulo, 1994.

${ }^{106}$ FARIA JUNIOR, Carlos. O Pensamento Econômico de José da Silva Lisboa, Visconde de Cairu. 2 vol., Tese de Doutorado em História Econômica - FFLCH-USP, São Paulo, 2008. ${ }_{107}$ ARRUDA, José Jobson de Andrade e Novais, Fernando. Prometeus e Atlantes na forja da Nação. Economia e Sociedade, Campinas, v. 12, n. 2 (21), 2003. 
Em texto mais recente, José Jobson Arruda ${ }^{108}$ vai além, ampliando sua análise a partir de uma metodologia instigante e original, e ponderando que "Cairu e sua apropriação da economia política em relação à política econômica pensada e, esta, em relação à vida econômica efetivamente vivenciada". (ARRUDA, 2014, p.334)

O autor questiona, deste modo, as interpretações mais exigentes da obra e que não enxergam em Cairu um pensador original, que tem na realidade e nas circunstâncias históricas elementos centrais das ideias que professa, logo,

"Ao acoimar-se Cairu de ser um áulico afeto à burocracia estatal, um quase sabujo dos poderosos, que se guiava exclusivamente pelos princípios da economia política - na busca do bem comum por via do desenvolvimento econômico e da harmonia social -, retira-se-Ihe aquilo que, a nosso ver, mais o tipifica no concerto dos pensadores da ilustração. Ao propugnar pela abertura dos portos, por exemplo, fundamentavase em razões objetivas, lastreadas na realidade histórica imanente, rejeitando-se, portanto, a possibilidade de interpretá-la estritamente na chave dos princípios teóricos por ele professados. Aí se conjugavam circunstâncias históricas específicas com a assimilação de princípios hauridos na literatura política, mas à realidade ajustados. Pensar o contrário seria negar a experiência prática que Cairu havia amealhado em sua carreira de funcionário público na Bahia, a qual desmente seu pretenso alheamento em relação à realidade econômica de seu tempo, compondo o perfil de um homem de gabinete, um funcionário prático". (ARRUDA, 2014, p.320)

Portanto, dessa forma, afasta-se e rejeita-se a visão de que José da Silva Lisboa seria um mero imitador de Adam Smith e simples divulgador das ideias liberais no Brasil. Para Arruda, a análise da obra de Cairu permite não só caracterizá-lo como pensador original, mas como pensador econômico, dotado de uma economia política, propositor e executor de uma política econômica, uma vez que teoria e prática estão sempre

${ }^{108}$ ARRUDA, José Jobson de Andrade. Cairu: texto e contexto. In: Historiografia: teoria e prática. São Paulo: Alameda, 2014. 
associadas à realidade econômica por ele vivenciada, ou seja, pensamento e ação se entrelaçam à história, como deve ser. As ideias de Cairu aparecem aqui como originais, não só porque partem de adaptações à realidade brasileira de teorias concebidas a partir de outra realidade histórica, mas porque dizem respeito ao contexto brasileiro ao mesmo tempo que o determinam.

"Sua economia política sim porque ela não era mera imitação, não instaurava o reino do liberalismo absoluto, preconizava a atuação do Estado a bem da felicidade social, do bem-estar social, porque fora pensada para uma realidade histórica totalmente diferente do ambiente europeu. Sua política econômica sim, porque a partir de suas reflexões projeta ações práticas, a serem conduzidas pelo Estado, almejando o desenvolvimento econômico por via do apoio às indústrias naturais, que incluiriam $\operatorname{sim}$ as indústrias mais complexas, no seu devido tempo. Teoria e prática sempre referenciada por Cairu às atividades econômicas efetivas, ou seja, aquelas atividades concretas, que a vivência histórica do período the prodigalizara, pois aí está o seu diferencial: passar da reflexão teórica (Economia Política) à formulação de práticas e ações econômicas (Política Econômica), referidas a uma realidade empírica objetiva, a realidade econômica efetiva, vivenciada, sentida, incorporada". (ARRUDA, 2014, p. 334)

José da Silva Lisboa também foi autor comentado em obras sobre a História do Pensamento Econômico Português. Moses Amzalak procurou analisar Cairu discutindo as influências da Escola Clássica em sua obra, bem como apresentando um perfil de sua vida e obra. ${ }^{109}$

Segundo Armando de Castro, "Silva Lisboa constitui um dos mais assinaláveis economistas da primeira metade do século XIX". (CASTRO, 1980, p.71) Para o autor, Cairu foi pensador teórico bem como lidou com problemas concretos, sendo que, nos Estudos do Bem Comum e Economia Política, constituiu "a primeira história do pensamento econômico, não só

109 AMZALAK, Moses B. Do estudo e da evolução das doutrinas econômicas em Portugal. Lisboa, 1928; AMZALAK, Moses B. José da Silva Lisboa, o visconde de Cairu (17561835). Revista Brasília, Coimbra, 1943. 
internacional como português, permitindo revelar as suas vastas informações". (CASTRO, 1980, p. 72-73)

Assim como outros autores portugueses, Castro destaca uma polêmica envolvendo Silva Lisboa e o economista português Joaquim José Rodrigues Brito. É o caso de José Luís Cardoso ${ }^{110}$, que bem resume a questão entorno das concepções a respeito da primazia ou não da Agricultura na geração de riquezas e do trabalho como fonte e medida de valor. Rodrigues Brito, seguidor dos fisiocratas e crítico de Adam Smith e, Cairu, defensor e seguidor do economista escocês. Cardoso consegue ilustrar e explicar muito bem a questão, mundos, contextos e realidades distintas que ensejam interpretações e explicações divergentes. Enquanto Rodrigues Brito vivia o mundo português da crise no início do século XIX, Silva Lisboa vivenciava a realidade Brasileira e as necessidades de transformações que a crise da economia colonial e a necessidade de um desenvolvimento econômico autônomo impunham.

José Luís Cardoso ${ }^{111}$ apresenta e interpreta Silva Lisboa como seguidor e discípulo de Adam Smith, que tentou aplicar à realidade brasileira os conceitos da Economia Política clássica e do liberalismo, cujo objetivo maior era defender a liberdade econômica, tanto no plano externo, com vias às questões comerciais, quanto no plano interno com vias ao desenvolvimento da manufatura. Em todos os casos, para Cardoso, Cairu era um espelho de sua realidade e contexto, qual seja, a necessidade de progresso e desenvolvimento econômico interno e autônomo do Brasil.

Mas, e as ideias de Cairu? A seguir, tentaremos sintetizar os pontos que consideramos mais importantes da obra e do pensamento econômico de José da Silva Lisboa, contrapondo tais pontos a partir das perspectivas

${ }^{110}$ CARDOSO, José Luís. O Pensamento Econômico em Portugal nos finais do século XVIII (1780-1808). Lisboa: Editorial Estampa, 1989 e ALMODOVAR, António; CARDOSO, José Luís. A History of Portuguese Economic Thought. Londres: Routledge, 1998.

${ }^{111}$ Além dos trabalhos já citados ver também CARDOSO, José Luís. O liberalismo econômico na obra de José da Silva Lisboa. História Econômica e Economia de Empresas, V.1, 2002. 
contrastantes a respeito de seu pensamento que apresentam nos parágrafos anteriores.

José da Silva Lisboa nasceu na Bahia em 1756 e faleceu no Rio de Janeiro em $1835^{112}$. Estudou em Coimbra, onde também lecionou grego e hebraico. Em Salvador, lecionou filosofia nacional e moral por 19 anos, além do grego, por 5 anos. Foi nomeado deputado e secretário da Mesa da Inspeção da Bahia em 1797, cargo que ocupou até 1808. Quando a família real chegou ao Brasil em 1808, acompanhou D. João até o Rio de Janeiro com a incumbência de auxiliá-lo na estruturação do Império a partir do Brasil.

Logo após sua mudança para o Rio foi nomeado desembargador da Mesa do Desembargo do Paço e da Consciência e Ordens. Em Agosto do mesmo ano, deputado da Real Junta do Comércio, Agricultura, Fábricas e Navegação do Estado do Brasil; em 1809 foi incumbido de organizar um código de comércio; em 1810 recebeu a mercê do hábito de Cristo; em 1815 foi encarregado especialmente do exame de obras econômicas para a impressão; em 1821, foi incluído na lista dos membros da junta de cortes para o exame das leis constitucionais discutidas então em Lisboa, e seguidamente inspector-geral dos estabelecimentos literários e diretor dos estudos.

Quando se discutia a separação do Brasil de Portugal, tentou mostrar e provar que a conciliação seria viável; para tanto, chegou a fundar o jornal O Reconciliador do Reino Unido. Quando o principe D. Pedro tomou a frente do processo de independência, nao hesitou em

\footnotetext{
${ }^{112}$ A historiografia tem indicado que a melhor referência biográfica a respeito do Visconde de Cairu tenha sido escrita por seu filho Bento da Silva Lisboa e apresentada ao IHGB em 1839. Ver SILVA LISBOA, Bento da. José da Silva Lisboa, Visconde de Cairú. Rev. do Instituto Histórico e Geográfico Brasileiro, Rio de Janeiro, v. 1, 1839.

Recentemente Teresa Cristina Kirschner publicou extenso, rico e completo estudo sobre o itinerário e a trajetória de José da Silva Lisboa. Ver KIRSCHNER, Tereza Cristina. José da Silva Lisboa, Visconde de Cairu: itinerários de um ilustrado luso-brasileiro. São Paulo: Alameda; Belo Horizonte: Ed. PUC-Minas, 2009.
} 
apoiar o movimento e tornar-se dele um fervoroso defensor. Após a independência, continuou a exercer cargos importantes e recebeu diversas distinções, inclusive a de Visconde de Cairu.

Além de toda trajetória destacada, foi designado por D. João VI para assumir a recém criada aula de Economia Política em 1808, no que foi a segunda medida legislativa decretada em 28 de fevereiro pelo príncipe regente quando chegou ao Brasil ainda em Salvador. A criação da cadeira visava proporcionar conhecimento erudito e prático, assim como fundamentar uma boa ação de governo ancorada no estudo da ciência que poderia contribuir para o progresso e a modernização da vida econômica e social do espaço colonial. Este episódio é um dos mais interessantes na história da difusão da Economia Política no Brasil ${ }^{113}$.

A cadeira nunca chegou a se efetivar de fato, contudo, a sua criação reflete diversas questões. Tivesse sido efeitivada a aula de Economia Política no Brasil, teria antecedido a ela não só na metropole portuguesa (implementada em 1836 em Coimbra sob a responsabilidade de Adriano Pereira Forjaz Sampaio) bem como na França (sobre a regência de Jean Baptiste Say, em 1816 para Hugon, em 1819 para Rocha e em 1824 para Nogueira de Paula) e na Inglaterra (de 1825 tendo como titular Nassau Senior). ${ }^{114}$

Essencialmente, tal episódio reflete, por um lado, a adequação da máquina de governo do Império português à sociedade brasileira, agregando intelectuais brasileiros à administração pública; por outro, a própria necessidade de formação de um quadro burocrático. Além disso,

\footnotetext{
${ }^{113}$ Ver ROCHA, Antonio Penalves. A Economia Política na sociedade escravista. São Paulo: Hucitec, 1996 e CARDOSO, José Luís. O liberalismo econômico na obra de José da Silva Lisboa. História Econômica e Economia de Empresas, V.1, 2002.

${ }_{114}$ Ver além de ROCHA (1996) também HUGON, Paul. A Economia Política no Brasil. In: AZEVEDO, Fernando de (org.). As Ciências no Brasil. 2a Ed., V.2., Rio de Janeiro: Editora UFRJ, 1994; GREMAUD, Amaury Patrick. Das controvérsias teóricas à política econômica: pensamento econômico e economia brasileira no segundo império e na primeira república (1840-1930). Tese (Doutorado em Economia) - Universidade de São Paulo, 1997; NOGUEIRA DE PAULA, Luiz. Síntese da Evolução do Pensamento Econômico no Brasil. Rio de Janeiro: Serviço de Estatística da Previdência e Trabalhos, 1942.
} 
Rocha chama a atenção para a necessidade da monarquia de angariar apoio na colônia, o que poderia ocorrer com a incorporação da intelectualidade local aos quadros burocráticos da Coroa, ademais, tal episódio reflete como, de alguma forma, o Estado teve um papel central na produção e irradiação das ideias econômicas no país. (ROCHA, 1996, p.36-37)

José Luis Cardoso aponta que tal episódio ilustra bem como as intenções dos legisladores ilustrados nem sempre tiveram repercussão prática e concreta, no entanto, mostra a necessidade que se verificava de aprendizagem de uma ciência que seria útil aos legisladores e governantes, desta forma, a criação pioneira mas frustrada da cadeira tem um sentido muito mais simbólico do que concreto. (CARDOSO, 2002, p.155)

Cardoso chama a atenção também para a preocupação de Silva Lisboa em fazer jus aos honorários de regente da cadeira de Economia Política, bem como em justificar a não implementação da aula, argumentando que ela seria insustentável no ambiente brasileiro, dado o baixo conhecimento inicial que a sociedade tinha da matéria. Cairu, assim, procura fazer jus à sua posição, publicando obras que permitiriam a formação dos interessados na matéria. De alguma forma, como chama a atenção Rocha (1996), os livros e publicações de Silva Lisboa, patrocinados pelo Estado, fariam jus à competência para qual fora indicado em 1808.

Sua primeira obra foi publicada em vários volumes entre 1798 e 1803, em Lisboa, Principios de Direito Mercantil e Leis de Marinha. Um dos seus trabalhos mais importantes, Principios de Economia Política, foi publicado em 1804, também em Lisboa ${ }^{115}$. Em 1808, publicou as

\footnotetext{
${ }^{115}$ Ver SILVA LISBOA, José. Princípios de Economia Política. Rio de Janeiro: Ed. Irmãos Pongetti, 1956.
} 
Observações sobre o Comércio Franco no Brasil ${ }^{116}$. Já em 1810, Observações sobre a Franqueza da Indústria e Estabelecimento de Fábricas no Brasil ${ }^{117}$. Finalmente, em 1819, publicou Estudos do Bem Comum e Economia Política ${ }^{118}$. Uma listagem completa, tanto das publicações de Cairu, bem como das publicações a seu respeito, está disponível na já citada obra de Teresa Cristina Kirschner.

José da Silva Lisboa foi o grande divulgador da Economia Política no Brasil no início do século XIX. O significado de seu pensamento foi fruto de diversas interpretações, como tentamos explorar nos parágrafos anteriores. Uns reconhecem a sua importância, enquanto outros o colocam como um burocrata que utilizou a Economia Política para justificar as ações do Estado e, com isso, ser promovido na escala da burocracia estatal. É preciso ressaltar, contudo, que Cairu foi um homem do seu tempo, fruto típico do contexto histórico luso-brasileiro entre o final do século XVIII e início do século XIX. Suas ideias manifestam as preocupações típicas de um intelectual formado a partir das ideias da ilustração portuguesa sob o contexto do movimento renascentista e iluminista, da emergência da Economia Política e das transformações e rupturas na Europa tais como a Revolução Industrial e a francesa, bem como do período napoleônico, da crise da economia e do sistema colonial, do rompimento dos laços coloniais e da emergência do Brasil como Nação. (CARDOSO, 2002; KIRSCHNER, 2009 E ARRUDA, 2014)

A vinda da corte para o país, em 1808, ocupa um papel especial para compreensão das ideias de José da Silva Lisboa. Tal episódio representou não só a cisão do pacto colonial, mas a necessidade de uma nova configuração e estruturação do Império Português. Neste processo, a

116 SILVA LISBOA, José. Observações sobre o Comércio Franco no Brasil In: José da Silva Lisboa, visconde de Cairu. São Paulo: Ed. 34, 2001.

117 SILVA LISBOA, José. Observações sobre a Franqueza da Indústria e Estabelecimento de Fábricas no Brasil. Brasília: Senado Federal, 1999. E também em José da Silva Lisboa, visconde de Cairu. São Paulo: Ed. 34, 2001.

118 SILVA LISBOA, José. Estudos do Bem Comum e Economia Política. Rio de Janeiro:

IPEA/INPES, 1975. 
Economia Política ocupou um lugar especial; desde a sua chegada ao Brasil, D. João VI implementou uma série de medidas que abriram a economia brasileira, livrando-a do exclusivo metropolitano. A Abertura dos Portos às Nações amigas e a revogação da proibição das manufaturas no Brasil são capítulos importantes de nossa história e tem papel central na compreensão das ideias de Silva Lisboa, além disso, as medidas de D. João procuravam, também, agradar em certos aspectos a elite agrária brasileira, que a tempos já se via insatisfeita com a coroa portuguesa. É, neste contexto, que precisamos entender a obra de Cairu.

Ao apresentar sua obra e ideias, Rocha aponta que os três principais temas de Silva Lisboa seriam a ordem natural, as funções do Estado e o livre comércio.

"Este conjunto, formado pelas articulações entre ordem natural, funções do Estado e livre-comércio, constitui uma teoria geral da sociedade, que merece ser recomposta porque sintetiza as ideias sociais, econômicas e políticas de Cairu." (ROCHA, 1997, p.77)

Além dos três temas elencados por Antonio Penalves Rocha, acreditamos ser essencial incluir, na análise, dada a sua importância, a indústria e a escravidão.

Cairu admitia a existência de uma ordem natural benéfica à humanidade, assim como a escola clássica.

"O Universo criado é um Sistema, organizado de partes, que estão em harmonia entre si, e com o Grande Todo, e é regido por Leis Imutáveis da Ordem Cosmológica, que a Inteligência Eterna determinou, e que invariavelmente se executam no Mundo Físico. A constância e imutabilidade dessas Leis é o fundamento de todos os nossos conhecimentos. Entretanto a Espécie humana naquele Sistema, não pode deixar de ser sujeita a essas Leis, e observá-las na sociedade civil, para a sua própria felicidade, e progressiva perfeição de sua natureza". (SILVA LISBOA, 1975, p.177) 
Para Silva Lisboa, ainda que os homens, pelo dom do livre arbítrio, violassem a ordem e as leis naturais, seriam punidos com o que aqui poderíamos descrever como atraso, ou, nas palavras do próprio Cairu, "ignorância, enojo, indigência, fome, dor, morte; ou contínuo desassossego, susto, e perigo da vida, tênue multiplicação, guerra, instabilidade das Associações Civis". De maneira oposta, os que seguissem tais leis seriam premiados com o progresso, a prosperidade do país e de toda a sociedade, "desfrutando pelo comércio franco, com muito menos seu trabalho, mais abundantes e variados produtos da terra e indústria dos mais países". (SILVA LISBOA, 1975, p.178)

Cabia à Economia Política restaurar tal ordem natural que, em algum momento da história, foi perdida pela ignorância e má escolha dos indivíduos e que se manifestava na atuação descabida e desnecessária do Estado. Para Cairu, a Economia Política, por definição, subordinava a "Riqueza Nacional à segurança e independência do Estado", o que não justificaria o que ele classifica como "monstruosas irregularidades", ou atuação excessiva do Estado. (SILVA LISBOA, 1975, p.174)

Cairu procura, deste modo, argumentar e defender a ideia de que só seria possível restabelecer a ordem natural a partir do estabelecimento de um sistema social "baseado na livre realização dos interesses pessoais. O "bem geral" surgiria espontaneamente da competição entre os homens, empenhados em realizar seus interesses próprios, sendo que a Mão Invisível do Criador acomodaria os conflitos que porventura viessem a ocorrer." (ROCHA, 1997, p.82)

Portanto, sua visão estava absolutamente ancorada na ideia do liberalismo, assim como em Adam Smith, aliás, as obras de Cairu, além de divulgadoras das idéias de Smith em vários pontos, eram traduções literais destas, sendo algo comum à época. Apesar disso, ele não se limitou a transcrever literalmente Smith e, além de traduções e interpretações de vários autores, Cairu adaptou algumas ideias de seu 
mestre à realidade brasileira. Enquanto Adam Smith via a felicidade coletiva associada à propriedade plena (direito de propriedade) e a liberdade de comércio e produção, Cairu acreditava que o bem geral seria alcançado pelo livre comércio. "Trocando em miúdos, para Adam Smith o sistema de liberdades naturais requeria a transformação da ordem econômica; para Cairu bastava a implementação do livre-comércio para alcançar o mesmo fim". (ROCHA, 1997, p.84) Isto se devia, para Penalves Rocha, à realidade brasileira, onde a propriedade já estaria bem definida segundo a propriedade capitalista. Isto reflete para Rocha, todavia, o compromisso de Cairu com a Coroa e com as elites agrárias brasileiras e, portanto, com a não transformação e sim adaptação da ordem econômica.

Acreditamos que a visão de Rocha, apesar de, por um lado, refletir um aspecto da obra de Cairu, sendo este a íntima relação com o Estado; por outro, acaba perdendo de vista a própria originalidade das suas ideias. Como bem caracterizou Arruda, sua apropriação de Smith foi de "um contorcionismo intelectual prodigioso" (ARRUDA, 2014, p.348), portanto, a forma como assimilou o economista escocês e o aplicou à realidade brasileira dizem muito a respeito da sua tentativa de conceber e demonstrar a existência da ciência da economia política que deveria servir de baliza para os atos governamentais. Considerar que a interpretação de Smith por Cairu teria como sentido apenas atender aos interesses da coroa e da elite local, ignora a perspectiva teórica que a sua obra enseja. Neste sentido concordamos com as observações de José Luis Cardoso ${ }^{119}$,

"direi que os escritos de José da Silva Lisboa, sempre
servidos por abundante retórica, se inscrevem numa
lógica de justificação e legitimação dos actos que o
Príncipe Regente e governo instalado no Rio foram
decretando, a fim de criar um espaço de maior abertura
económica no território brasileiro. Visavam convencer e
persuadir a opinião pública sobre a correcção e
bondade das medidas, ao mesmo tempo que servem

${ }^{119}$ CARDOSO, José Luís. 1808: o ano zero da autonomia econômica do Brasil. In: COUTO, Jorge (dir.). Rio de Janeiro Capital do Império Português (1808-1821). Fundação Calouste Goubenkian, 2010. 
para fixar o quadro doutrinal e teórico que Ihes confere coerência estratégica. Por outras palavras, Silva Lisboa não queria apenas aplaudir o que estava a ser feito. Pretendia também demonstrar a existência de princípios e meios universais - a ciência da economia política, convém recordar - que guiam o nosso entendimento sobre o verdadeiro significado dos actos de legislação e de governo, ao mesmo tempo que explicam como melhor se atinge a felicidade pública e o bem comum". (CARDOSO, 2010, p.124)

Quanto à questão do Estado, Silva Lisboa acreditava que sua atuação deveria ser limitada, no entanto, defendia que o este mesmo estado deveria ser o responsável pelo restabelecimento da ordem natural. Uma aparente contradição, contudo, "solicitava a intervenção do Estado, para que o Estado deixasse de intervir na ordem social" (ROCHA, 1997). Assim, cabia ao Estado remover certas restrições que impediam o funcionamento da Ordem Natural e, a partir daí, não mais interferiria nas questões da liberdade econômica e propriedade. Nesse sentido, suas ideias iriam embasar algumas medidas tomadas por D. João VI, como a Abertura dos Portos e a Revogação da Proibição das manufaturas e indústrias.

Para Cairu, o Estado deveria se integrar à ordem natural e ser reduzido às ações de segurança, justiça e manutenção dos órgãos públicos. Suas ideias eram tipicamente liberais e condizentes com a Economia Política de Smith. Para ele, a Riqueza Nacional estaria subordinada à segurança e independência do Estado, o que não justificaria o excesso de participação do Estado, cuja função maior deveria ser a de fazer prevalecer os princípios econômicos. Evidentemente, a prosperidade está ligada, para Cairu, à garantia de leis que permitam os princípios da Economia Política funcionar.

Percebemos, na Economia Política de Cairu, uma clara relação entre a ciência e prática tomada pelos Estados e governos afim de garantir a prosperidade para a sociedade e as nações. Nos Princípios de Economia Política, Cairu define a Economia Política como "a ciência e arte de prover 
às necessidades e comodidades de uma Nação, para o fim da maior opulência dos particulares e do Estado". (SILVA LISBOA, 1956, p.115) O sentido da ciência da economia, que serviria ao bem comum, é enunciado pelo autor, "dar o Governo a maior segurança, às pessoas, propriedades, e racional franqueza e garantia às convenções, e a mais extensa e liberal correspondência mercantil com todo o Mundo". (SILVA LISBOA, 1975, p.174)

Como fica claro, em relação ao Comércio a posição de Cairu, sempre esteve ligada à defesa integral do livre mercado, que seria o responsável por trazer grandes benefícios à nação e a sociedade. O Livre comércio estaria vinculado à noção de ordem natural e beneficiaria sempre ambas as partes envolvidas na relação de troca, qualquer que fosse a situação, desta maneira, seria capaz de promover o desenvolvimento econômico. Com esses argumentos, Cairu encontrava elementos para justificar as medidas da Coroa portuguesa, principalmente no que diz respeito à Abertura dos Portos às Nações amigas em 1808.

As posições de Cairu a respeito do comércio franco são amplamente fundamentadas a partir das doutrinas dos pensadores liberais e principalmente em Adam Smith. Silva Lisboa defende que o livre comércio seria benéfico às nações e crê, assim como Smith, no caráter cooperativo da sociedade.

"O verdadeiro espírito do comércio é social; ele quer
ajudar, e ser ajudado, ele aspira a dar socorro, e
recebê-lo, ele carece um benefício recíproco, e não é
fecundo, e constantemente útil, senão quando é
repartido". (SILVA LISBOA, 2001, p.72)

Evidentemente que o tema do comércio, ou comércio franco, em sua obra, está diretamente relacionado à sua tentativa de justificar a Abertura dos Portos em 1808. É evidente que a obra de Cairu tem diversas possibilidades de interpretação. De um lado, é possível identificar, em seus escritos, o grande esforço de síntese teórica da Economia Política, bem como o empenho em provar que a ela não só seria aplicável como a 
solução para o desenvolvimento e o progresso luso-brasileiro; de outro, fica claro também o peso que a política e que sua posição burocrática impõe às suas ideias. No caso do comércio, Cairu defende o livrecambismo e sustenta sua visão com argumentos sofisticados e bem fundamentados no que havia de mais moderno em termos teóricos. Da mesma forma que defende que o livre comércio com a Inglaterra é mais fundamental do que com outras nações.

"Se a franqueza do comércio com todas as nações é útil no Brasil, ela é imprescindível com os ingleses, por necessidade, interesse, política, e gratidão nacional". (SILVA LISBOA, 2001, p. 75)

Da mesma forma, Cairu parece defender fiel e cegamente as teorias liberais e o comércio franco, ancorando os seus argumentos em aspectos práticos (da própria realidade luso brasileira) e teóricos, mas não deixa, em diversas passagens, de abrir espaço para uma visão menos radical das suas posições teóricas e mais ligadas à uma leitura das especificidades nacionais na questão comercial. Imprescindível ressaltar que o essencial e fundamental em todos os momentos da obra de Silva Lisboa é buscar sempre o que seria melhor para o progresso do Estado e da Nação.

"Não dissimulo, que as vantagens do comércio franco têm sido controvertidas por escritores de nota; e que circunstâncias de cada país podem justificar algumas restrições, temporárias, ou permanentes, do tráfico estrangeiro, compensando-se, por cálculo prudente, com o bem geral. Assim protesto, que em nada intento deprimir o patriotismo, e mérito dos que discordam de mim em tal assunto. Respeito o juízo de todos; não presumo que o meu seja a medida da verdade, só desejo que prevaleça o que for realmente mais útil ao Estado". (SILVA LISBOA, 2001, p. 65-66)

Neste sentido, não nos parece justo, com a obra de Cairu, apontá-lo como um mero servidor e burocrata a serviço da realeza. Sua obra tem uma pretensão teórica e uma preocupação que transcendem tal questão. Como afirmamos anteriormente, Silva Lisboa tem a intenção de demonstrar de forma teórica e prática que a Economia Política não só 
pode ser aplicável à realidade luso-brasileira como seria a solução para o seu desenvolvimento e progresso, desse modo, acredita que, "a boa ordem, segurança, e independência de cada Nação, dependem essencialmente do progresso da indústria, riqueza, e prosperidade pública". (SILVA LISBOA, 1975, p.174)

A indústria, portanto, é outro tema de enorme importância na obra de Cairu, seja pelo lugar que ocupa em seus escritos mais teóricos, seja pela sua posição fundamental nas questões mais práticas, como no caso de sua justificativa para a medida de revogação da proibição das manufaturas no Brasil.

Assim, no caso da indústria, José da Silva Lisboa defendia as medidas de Dom João VI, especificamente na revogação do alvará que proibia as manufaturas no Brasil, apesar de crer na vocação agrária brasileira. Para Cairu, a nação deveria ser livre para desenvolver a indústria e isso seria benéfico para a liberdade, entretanto, acreditava que as leis naturais acabariam por indicar que a nação não desenvolveria profundamente a indústria, concentrando-se assim na produção agrária.

Esta defesa, para Rocha, estaria ligada claramente aos objetivos do discurso de Cairu, que procurava dar embasamento filosófico às medidas tomadas pelo príncipe regente. Evidentemente que esta interpretação encontra amparo na obra de Silva Lisboa, como no caso da questão comercial, por outro lado, é preciso reconhecer e, em sua obra esta questão aparece nitidamente, que toda a defesa da liberdade para a indústria, a manufatura e as fábricas no Brasil é amplamente sustentada com base em um discurso teórico muito bem fundamentado no que havia de mais moderno em termos da Economia Política, bem como nos pensadores liberais mais importantes da época. Não há como ignorar que tal questão se enquadra perfeitamente na tentativa de Cairu de provar, em termos práticos, a partir da realidade brasileira, os princípios teóricos 
do liberalismo e da Economia Política, ou seja, ressaltar a importância da liberdade e da garantia para a livre iniciativa nos negócios.

Claramente Silva Lisboa considerava as atividades agrícolas mais importantes na economia brasileira. É nítida sua visão derivada de Smith da sociedade como uma grande fábrica onde há a divisão do trabalho. Assim, nesta divisão, o Brasil contribuiria com artigos agrícolas em virtude de sua realidade e história.

Cairu acreditava que a realidade brasileira teria íntima relação com as atividades produtivas que aqui deveriam se estabelecer, ou seja, não nos parece correto associar a incontestável defesa do livre comércio, da primazia da livre iniciativa e da agricultura como ramo mais forte da economia em virtude de uma espécie de "divisão internacional do trabalho", como uma defesa de interdição ou limitação a fabricas e manufaturas. Ao contrário, Cairu atribuía grande importância às atividades internas, estabelecendo como fundamental o comércio e a circulação de mercadorias no mercado interno.

Logo, o Brasil contribuiria no mercado internacional com produtos agrícolas, enquanto importaria artigos manufaturados, principalmente os de luxo, não obstante, no plano interno, haveria de se desenvolver através de atividades menos complexas e que seriam responsáveis por abastecer a demanda interior. A liberdade e a franqueza da indústria, consequentemente, seriam fundamentais. Somente a livre iniciativa seria capaz de indicar o caminho para o bem comum, que passaria pelo estabelecimento de atividades de forma natural, atendendo as necessidades internas e dando suporte à integração internacional através do livre comércio.

Ressalte-se, contudo, que, apesar de teórica, toda visão de Cairu tem um sentido prático e de leitura da realidade fundamentais. É o que notamos, por exemplo, quando ele elenca seus objetivos gerais ao defender a franqueza da indústria e abrir espaço para incentivos à 
implementação de grandes máquinas e manufaturas de investimento muito elevado. A defesa da franqueza da indústria e do comércio prevalecem, são amplamente dominantes, mas exceções associadas à realidade vivida e prática sempre aparecem demonstrando o grande sentido teórico adaptativo de Silva Lisboa.

"O Brasil pode ainda por longo tempo ter muita indústria e riqueza, sem estabelecer as fábricas refinadas, e de luxo que distinguem a Europa (...) As fábricas que por ora mais convêm ao Brasil são as que proximamente se associam à agricultura, comércio, navegação, e artes da geral acomodação do povo. (...) Não convém (por via de regra) dar privilégios exclusivos aos que não são inventores e introdutores de novas máquinas, e invenções nas artes: mas é racionável darem-se alguns especiais auxílios e favores aos primeiros introdutores de grandes máquinas, e manufaturas de muito dispêndio, posto que já assaz conhecidas, em proporção aos objetos de evidente proveito do país (...) A estabilidade do princípio da franqueza da indústria, sendo consequente ao da franqueza do comércio, é o meio eficaz de fazer introduzir e aperfeiçoar os mais úteis estabelecimentos, com maior rapidez, e incessantemente progressiva energia pública para a opulência e população do Brasil". (SILVA LISBOA, 1999, p. 35)

Agora abordaremos a questão da escravidão na obra de José da Silva Lisboa. Apesar de ser contrário e um defensor do trabalho livre, tal qual os economistas políticos clássicos, defendia a escravidão no Brasil, dada as suas circunstancias e peculiaridades que impediam a adoção do trabalho livre.

Desta forma, abordava a escravidão como se essa fosse um mal necessário. Seria impossível acabar com ela abruptamente, pois destruiria o país (Cairu era contra qualquer tipo de mudança radical). Defendia a ideia de que medidas graduais acabariam com a escravidão (defendia o fim do tráfico como ponto de partida). É impossível não relacionar suas 
ideias às ideias das elites agrárias brasileiras que comandaram tal processo a partir de $1850^{120}$.

Assim, examinando as ideias e o pensamento do Visconde de Cairu, Rocha (1997) argumenta que precisamos considerá-lo como um personagem do processo de formação do Estado nacional e a Economia Política como um dos elementos que dão embasamento aos objetivos políticos de uma elite conservadora. Para o autor, Cairu era um Burocrata, não acadêmico, cuja vinculação com a formação e atuação na área do Direito dava a suas ideias econômicas sempre um caráter jurídicoeconômico.

"Em suma, diante dessa descrição da composição dos livros de Cairu podemos concluir que, em termos de investigação econômica, nada se encontra de original nos seus escritos.

Esta falta de originalidade se conjuga a algo que já foi enunciado anteriormente: as reflexões sobre o mundo econômico propriamente dito não constituíram o objeto central da Economia Política de Silva Lisboa". (ROCHA, 1997, p.74-75)

Nos parece claro e evidente que a interpretação de Antonio Penalves faz sentido e tem bastante coerência, contudo, é preciso reconhecer em Cairu um pensador e intérprete original. Sua leitura e síntese da Economia Política tinham uma preocupação teórica e prática e sua originalidade está sobretudo em interpretá-la à luz da realidade e especificidade brasileira.

Além disto, é preciso ressaltar que, o conhecimento teórico ${ }^{121} \mathrm{e}$ erudição ${ }^{122}$ de José da Silva Lisboa o levam, em determinados momentos,

\footnotetext{
${ }^{120}$ Sobre essa questão ver COSENTINO, Daniel. Um múltiplo de transições: a transição do trabalho escravo para o trabalho livre em Minas Gerais. Dissertação (Mestrado), UNICAMP, 2006; COSTA, Emilia Viotti. A Abolição. São Paulo: Global Ed., 1982.

121 José Luis Cardoso e José Jobson Arruda chamam a atenção para a questão e para o vasto conhecimento teórico de Cairu. Tal elemento é facilmente identificável pela leitura de seus textos e constatação do intenso diálogo que estabelece com o que havia de mais moderno na literatura da época.

${ }_{122}$ Erudição no sentido pleno. Cairu não demonstrava conhecimento apenas no campo da Economia Política, seus escritos transparecem um grande conhecedor da literatura política, filosófica e jurídica. Ademais, Cairu ao que tudo indica, se arriscava também em
} 
a transcender o papel de difusor das ideias econômicas. É o que propõe por exemplo José Luis Cardoso ao discutir um texto menos conhecido de Cairu.

Segundo Cardoso, Cairu tinha um conhecimento e domínio muito elevado da Economia Política, sendo sua visão tão vanguardista, ao defender o livre comércio como forma de enriquecimento das nações, ao ponto de apresentar uma leitura parecida, e anterior, a Ricardo em defesa da especialização produtiva e das vantagens comparativas.

"Num desses textos - porventura o menos conhecido de
todo eles intitulado Refutação das Declamações Contra
o Comércio Inglês, Extraída de Escritores Eminentes,
datado de 1810 - Silva Lisboa defende com clareza a
ideia de vantagens recíprocas no comércio baseadas no
cálculo das horas necessárias para a produção de
determinados bens, devendo cada país tirar vantagem
de uma especialização nos bens que produz em
melhores condições, ou seja, com menos horas de
trabalho. Sem pretender dizer que estamos perante
uma visão avant la lettre da tese que o economista
David Ricardo tornou célebre em 1817 sobre as
vantagens comparativas no comercio internacional, é
de elementar justiça reconhecer a modernidade do
pensamento de Silva Lisboa que, deste modo, revela
comungar os princípios melhor sustentados de defesa
do livre-câmbio como factor de enriquecimento de cada
nação e do conjunto das nações". (CARDOSO, 2010, p.
123 )

Modernidade que podemos verificar em outras passagens de sua obra também. Aqui selecionamos especificamente um trecho em que sua visão do funcionamento da economia em muito se assemelha a visão contemporânea e que se vai difundir mais largamente a partir do século XX na teoria econômica neoclássica mainstream.

"os capitais de particulares só podem crescer pelo que cada indivíduo pode anualmente poupar do seu

outros campos, como o da poesia. É o que revela o curioso e riquíssimo estudo de Pablo Magalhães. Ver MAGALHÃES, Pablo A. Iglesias. Flores Celestes: O livro secreto de José da Silva Lisboa, o visconde de Cairú?. História (São Paulo). v.31, n.1, p. 65-100, jan/jun 2012. 
consumo sobre seu rédito, isto é, da sobra da sua receita e da sua despesa. Ora, quando qualquer pode ter mais baratos os artigos de seu suprimento, tanto maior pode ser o excedente do rédito a respeito do consumo, ou a dita sobra da receita a respeito da despesa. A nação não é mais que a coleção de indivíduos que a compõe; e, portanto, os seus capitais só podem crescer precisamente do mesmo modo, isto é, conforme o corpo do povo pode ter seu suprimento mais barato. E como é indubitável que isto só pode acontecer em proporção da maior quantidade dos gêneros nacionais e estrangeiros pode ocasionar a maior quantidade e barateza possível de tais gêneros, e tal concorrência não pode existir senão com a absoluta franqueza do comércio interior e exterior; segue-se, que só com essa franqueza é que o Brasil pode se elevar ao maior grau de riqueza e prosperidade de que é capaz" (SILVA LISBOA, 2001, p. 138)

Algo nos parece definitivo: Cairu como pensador econômico original e intérprete da realidade brasileira.

\section{O Ensino de Economia Política no Brasil durante o século XIX}

Como discutido ao longo do capítulo anterior, um dos elementos essenciais quando pensamos o Pensamento Econômico Brasileiro é a questão de como a economia entrou e se difundiu pelo Brasil. Neste aspecto, dois trabalhos importantes são os de Paul Hugon e Amaury Gremaud $^{123}$. São estudos que abordam o tema de forma semelhante. $O$ objetivo dos dois parece ser mostrar como e de que forma a Economia Política chegou ao Brasil, assim, procuram apresentar como se iniciou e de que forma se deu o ensino de Economia Política no país, que preparava e formava a intelectualidade brasileira que, em algum momento, seria responsável pela formulação da política econômica nacional. "Assim busca-se apreender que tipo de concepção de Economia Política e, dentro

\footnotetext{
${ }^{123}$ HUGON, Paul. A Economia Política no Brasil. AZEVEDO, Fernando de (org.). As Ciências no Brasil. 2a Ed., V.2., Rio de Janeiro: Editora UFRJ, 1994; GREMAUD, Amaury Patrick. Das Controvérsias Teóricas à Política Econômica: pensamento econômico e economia brasileira no segundo império e na primeira república (1840-1930). Tese (Doutorado em Economia) - Universidade de São Paulo, 1997.
} 
desta, de teoria monetária, fazia parte da formação acadêmica dos futuros formuladores da política econômica nacional." (GREMAUD, 1997, p.7)

Gremaud argumenta que faz sentido estudar o Pensamento Econômico Brasileiro durante o século XIX, pois, apesar de todos os problemas envolvidos, a ausência de "economistas técnicos", ou institutos especializados, a elite intelectual recebeu formação em Economia Política, conheceu os teóricos da época e essa formação teve papel importante no debate e na formulação da política econômica durante o período imperial.

Outros trabalhos também se preocuparam com a questão. 0 pioneiro talvez seja o de Luiz Nogueira de Paula, ${ }^{124}$ em 1942, onde apresenta os catedráticos e professores de Economia Política nas primeiras faculdades de Direito e Engenharia do Brasil. Seu trabalho, juntamente com o de Paul Hugon inspiraram o breve relato sobre o ensino de Economia que Heitor Ferreira Lima ${ }^{125}$ faz em seu livro clássico História do Pensamento Econômico no Brasil.

Assim como Hugon e Gremaud, mas de forma mais sintética, Dorival Teixeira Vieira ${ }^{126}$ apresenta a História da Ciência Econômica no Brasil, dando destaque a introdução da economia no ensino universitário, apresentando também os primeiros lentes de Economia Política no Brasil durante o século XIX.

Além dos citados, em tese defendida em 2002, Julio Cesar Bentivoglio $^{127}$ também explora o tema na tentativa de entender a articulação entre a política econômica em meados do século XIX e a elaboração do Código Comercial e consolidação do Império no Brasil.

\footnotetext{
124 NOGUEIRA DE PAULA, Luiz. Síntese da Evolução do Pensamento Econômico no Brasil. Rio de Janeiro: Serviço de Estatística da Previdência e Trabalhos, 1942.

${ }^{125}$ LIMA, Heitor Ferreira. História do Pensamento Econômico no Brasil. São Paulo: Cia Ed. Nacional, 1976.

${ }^{126}$ VIEIRA, Dorival Teixeira. A História da Ciência Econômica no Brasil. In: FERRI, Mário Guimarães; MOTOYAMA, Shozo. (coordenadores). História das Ciências no Brasil. São Paulo: EPU: Edusp, 1979-1981.

${ }^{127}$ BENTIVOGLIO, Julio Cesar. O Império das Circunstâncias - O Código Comercial e a política econômica brasileira (1840-1860). Tese de Doutorado História Econômica. FFLCH-USP, 2002.
} 
Inspirado no trabalho de Nogueira de Paula, Luiz de Freitas Bueno ${ }^{128}$ também apresenta a evolução do ensino de Economia no país dando ênfase na questão curricular, até a formação dos cursos superiores em Economia em meados do século passado.

O ensino de Economia Política no Brasil teve seu marco inicial quando, em 1808, o príncipe regente D. João VI atribuiu a José da Silva Lisboa a Cátedra de Economia Política, como discutido na seção anterior. Desta forma, Cairu passou a ser conhecido como o primeiro professor de Economia do país. O curso acabou não se efetivando. De qualquer forma, a criação da Cátedra é significativa e simbólica. Foi anterior ao ensino oficial de Economia na França, na Inglaterra e em Portugal.

Como vimos, o Visconde de Cairu publicara, quatro anos antes ser indicado à cátedra, os seus Princípios de Economia Política, que tinha como objetivo divulgar os princípios de Economia Política e mais precisamente as ideias de Adam Smith. Devemos ressaltar, por um lado, a importância da Economia Política como forma de divulgação das ideias liberais que se desenvolviam na Europa e, de outro, a apropriação de tais ideias por aqui, o que acabava por the conferir certos traços de originalidade.

Hugon nos mostra que "É exclusivamente no quadro das faculdades de direito que, no Brasil, se ensina Economia Política de 1827 a 1863". A lei de 11 de agosto de 1827 criou os cursos jurídicos e sociais em São Paulo e Olinda. Os livros indicados para o estudo de Economia Política eram os de Smith, Malthus, Ricardo, J.B. Say, Sismondi e Godwin. Eram os livros oficiais; os professores deveriam se inspirar neles para organizar o programa e os alunos recorreriam a eles para completar as aulas dadas. De um lado a Economia Política Inglesa com Smith, Malthus e Ricardo; de outro, a Escola Liberal Clássica Francesa com Say. Estes autores refletem a influência do liberalismo clássico europeu. Em uma vertente, está a

\footnotetext{
${ }^{128}$ BUENO, Luiz de Freitas. A evolução do ensino de economia no Brasil. Ensaios econômicos da EPGE, n.5. Rio de Janeiro: IBRE/FGV, 1972.
} 
presença de Sismondi (economista e historiador cujas críticas feitas ao sistema liberal foram tão vigorosas e exatas que, como mostra Hugon, servirão de ponto de partida ao intervencionismo e o socialismo) e Godwin (grande representante do socialismo do século XVIII, na Inglaterra que, como mostra Hugon, proclama as maravilhas da harmonia dos interesses fora do quadro da propriedade privada, instituição na qual vê a causa da desigualdade social e da pobreza), representando o ponto de vista de que os estudos de economia no Brasil do século XIX não se apoiaram exclusivamente na cópia da escola clássica inglesa. Isto caracterizaria uma espécie de hibridismo no ensino de economia no Brasil segundo Vieira. Nas palavras de Hugon:

"Seria pois, inexato afirmar, como se faz muitas vezes, que a orientação dos estudos econômicos no Brasil do século XIX apoiou-se apenas em ideias "copiadas" da escola clássica inglesa.

Indicamos, ao tratar das contribuições de Cairu, que, desde os seus primórdios, e mesmo antes de ter sido organizado e difundido o ensino oficial, o pensamento econômico, abeberando-se grandemente na ciência clássica liberal inglesa, revestia certos aspectos estritamente nacionais. Vemos agora que, em suas primeiras manifestações universitárias, segundo a lista de compêndios à escolha dos primeiros mestres, não se limitava exclusivamente às obras e às ideias do liberalismo econômico." (HUGON,1957, p.350-351).

O ensino de Economia Política na Faculdade de Direito de Olinda ${ }^{129}$ teve forte influência de James Mill (pai de Stuart Mill), portanto da escola clássica inglesa. O primeiro professor, Pedro Autran da Mata e Albuquerque (1805-1881), aponta Hugon, foi nomeado catedrático em $1832^{130}$, traduziu e publicou os Elementos de Economia Política de James Mill de 1820. Segundo Hugon, ficou em Pernambuco até $1858^{131}$, quando

\footnotetext{
${ }^{129}$ Segundo Gremaud o curso começo a ser oferecido em Olinda, tendo se transferido para Recife por volta de 1853-1854, na mesma época em que os cursos jurídicos passaram a se denominados como Faculdade de Direito. (Gremaud, 1997, p.31)

${ }^{130}$ Para Nogueira de Paula (1942) a nomeação ocorreu em 1827.

131 Já Nogueira de Paula (1942) aponta que o catedrático se transferiu para o Rio de Janeiro em 1870 quando foi jubilado.
} 
foi para o Rio, onde continuou a ensinar Economia Política no Instituto Comercial e na Escola Normal.

James Mill foi uma grande influência para o professor, que teve sua formação em Direito em Aix, na França. A escolha de Mill como grande influência, segundo Hugon, foi importante porque, além de sintetizar as ideias de Say, permitia a apreensão da filosofia de Bentham e da economia ricardiana. As ideias econômicas e filosóficas de Albuquerque se caracterizavam por serem bem completas, ecléticas e atuais para a época. Tais características foram marcantes em suas aulas e nos livros que publicou sobre Economia Política. Estes serviram e influenciaram de forma importante todo o ensino da matéria em Pernambuco. Nogueira de Paula (1942) aponta que sua influência não se restringiu a Recife/Olinda, sendo que suas obras também foram utilizadas como livro texto no Rio de Janeiro e em São Paulo ${ }^{132}$.

Em sua tese de doutorado, Amaury Gremaud (1997) analisa Preleções de Economia Política, apontando que Albuquerque seguiu Mill ao subdividir a apresentação da Economia Política em quatro partes: Produção, Circulação, Distribuição e Consumo, diferenciando-se assim de Say ao acrescentar a esfera da Circulação. Tal divisão marcaria praticamente todos os manuais ${ }^{133}$ elaborados pelos professores das Faculdades de Direito no Brasil e, para Gremaud, reflete "a importância do estudo da circulação, que envolve as trocas e as questões monetárias e financeiras (...) demonstrando a continuidade das preocupações com os

\footnotetext{
132 Nogueira de Paula (1942) listou como principais obras de Autran: Elementos de Economia Política (1884) - Gremaud (1997) aponta que tal obra seria de 1844, o que faz mais sentido, Novos Elementos de Economia Política (1851), Preleções de Economia Política (primeira edição de 1859 e segunda de 1862), Manual de Economia Política (1880) - segundo Gremaud, publicado em 1873 - e Catecismo de Economia Política (1880).

${ }^{133}$ Gremaud afirma que tais livros "são destinados aos estudantes dos cursos de Direito e têm por objetivo compendiar os principais escritos de Economia Política. Nestas obras, não há preocupação com plágios ou apropriação das ideias alheias, o objetivo é resumir as doutrinas sem preocupação com atribuição das ideias aos seus formuladores". (GREMAUD, 1997, p.32)
} 
aspectos comerciais, e agora também financeiros, que já marcaram os precursores da Economia Política no país". (GREMAUD, 1997, p.32)

Durante a obra, Autran mostra alguma influência de alguns conceitos do utilitarismo ao lado dos conceitos clássicos apresentados por Adam Smith, relacionando a produção à satisfação das necessidades humanas e à geração de prazer. É a apreciação da esfera da circulação, contudo, que apresenta características mais interessantes, pois 0 catedrático atribui importância central ao mercado monetário, sobretudo a demanda por moeda para intermediação das transações comerciais (relacionadas ao desenvolvimento da sociedade) e a preocupação com o desenvolvimento de mecanismos monetários alternativos à moeda metálica. Ademais, discute o funcionamento e organização do sistema bancário e dos mecanismos de criação de moeda. (GREMAUD, 1997)

Fica clara, apesar de não mencionar especificamente, a influência da realidade brasileira na análise e a questão/debate que marcará o país por muito tempo a respeito da conversibilidade e do lastro da moeda, desse modo, Autran defende que a oferta de moeda deveria se adaptar às necessidades dos negócios de cada país, sendo que, ao sinal de problemas na oferta de moeda metálica, instrumentos monetários alternativos deveriam ser empregados. Como bem expõe Gremaud,

"apesar de Albuquerque pouco se referir ao Brasil quando se trata das questões monetárias suas posições parecem bastante relacionadas ao caso brasileiro. Por um lado sua insistência na necessidade de economia da moeda metálica é bastante adequada às condições brasileiras, já que a falta de metais era uma característica crônica de nossa economia no período. Deste modo afigurava-se para o autor a possibilidade e mesmo a necessidade de substituí-la com moeda fiduciária sem que isto provocasse grandes traumas à nossa economia, muito pelo contrário. Por outro lado a emissão fiduciária tinha também um caráter estabilizador frente às oscilações na quantidade de metal entrando e saindo do país, o que também parecia uma característica que se adaptava as condições 
brasileiras. Por fim a defesa de um sistema de pluralidade emissora era um dos polos do debate acerca de como se deveria instituir o sistema monetário e bancário brasileiro na época". (GRAMAUD, 1997, p.38)

As ideias do professor Pedro Autran da Mata e Albuquerque foram questionadas por outro catedrático da faculdade pernambucana, Lourenço Trigo de Loureiro (1793-1870 $)^{134}$, segundo aponta Luiz Nogueira de Paula, em Elementos de Economia Política, de 1854. Uma das divergências estaria relacionada primeiro à tradução que Autran realizou de James Mill, além disso, tinha intenção de substituir o trabalho de Albuquerque como referência básica para os cursos de Direito.

A obra de Loureiro foi examinada por Amaury Gremaud que aponta que, apesar das discordâncias, a esfera da circulação, e decorrente dela, os temas envolvendo o comércio e as questões monetárias, são temas de destaque em ambos.

Para Gremaud, as principais divergências seriam que, ao contrário de Autran, Loureiro ressalta o caráter empírico da Economia, além de ter uma concepção menos harmoniosa da sociedade, de questionar de alguma forma a lei de Say, reconhecer a possibilidade de crises no sistema e atentar para a importância da intervenção governamental. No campo monetário, a visão dos autores se aproxima, como bem resume Amaury Gremaud,

"a visão de Loureiro sobre as questões monetárias se aproxima das de Albuquerque ressaltando a necessidade de mecanismo de substituição da moeda metálica. Esta substituição seria melhor feita por um sistema de pluralidade emissora com base em moeda conversível. As emissões, apesar de lastreadas, não precisam se relacionar diretamente ao estoque de metais existentes. A diferença é que para Loureiro a atuação estatal de vigilância e supervisão é importante

${ }^{134}$ Segundo Paul Hugon, Loureiro não teria assumido a cadeira de Economia Política. Nogueira de Paula (1942, p.23) argumenta que ele sucedeu Albuquerque, assim como Dorival Vieira (1981, p.353) e Amaury Gremaud. O último aponta que, na dedicatória do livro de 1854, Loureiro afirmara ser o responsável pela matéria. (GREMAUD, 1997, p.38) 
para imputar confiança ao sistema e evitar excessos. Esta supervisão se faz sobre a relação quantitativa emissão-garantias, incluindo nestas garantias não apenas as moedas metálicas mas também títulos privados". (GREMAUD, 1997, p.42)

O sucessor de Loureiro foi Aprígio J. da Silva Guimarães (18321880) que ingressou como docente na Faculdade de Direito de Recife em 1859 e ocupou a cadeira de Economia Política até 1871. O professor Aprígio seguia uma tendência parecida à de Autran, mas distinguiu-se por encaixar os estudos em Economia na Sociologia. Nesse ponto, sofre a influência de Stuart Mill, que trata do caráter social da Economia Política. Antecipa uma tendência sociológico-econômica que se desenvolverá no final do século XIX. O seu livro, Estudos de Economia Política, foi publicado postumamente em 1912, com prefácio de Clóvis Beviláqua.

Em tal obra, Guimarães difere substancialmente de Autran e Loureiro, como ressalta Gremaud, ao não fazer uma exposição sistemática dos princípios da Economia Política e ao centrar suas atenções em questões referentes à metodologia.

Com a morte de Aprígio, Nogueira de Paula (1942) afirma que a escola econômica de Recife entrou em declínio. Seus sucessores foram José Joaquim Tavares Belford (1840-1887), sucedido por Sinfrônio Eutiquiano de Paz Portela (1852-1935) e este por Alfredo Alves da Silva Freyre. Amaury Gremaud (1997) aponta que não há registros de publicações relevantes referentes à Economia dos acima citados.

Sintetizando, a escola de Recife foi responsável pelas primeiras publicações acadêmicas de Economia Política no Brasil, como aponta Gremaud (1997). Além disso, podemos constatar que o ensino que ali se praticava, apesar da influência teórica sobretudo clássica inglesa, tinha preocupações que decorriam da realidade brasileira, sobretudo no aspecto monetário e financeiro. 
Os cursos de Economia Política na Faculdade de Direito de São Paulo também se iniciaram em 1832. Ao contrário dos professores pernambucanos, os primeiros catedráticos paulistas não publicaram livros didáticos relevantes, segundo aponta Gremaud (1997), no entanto, verificamos que tais docentes tiveram uma participação bastante ativa e importante na vida política brasileira.

O primeiro titular da cadeira de Economia Política foi Carlos Carneiro Campos, o Visconde de Caravelas. O docente estudou em Paris e assumiu a cátedra a partir de 1829 tendo a influência de seu grande mestre, J. B. Say, em sua obra, Catecismo de Economia Política. Durante um ano (1858-1859) a cadeira foi regida por Luís Pedreira de Couto Ferraz, o Visconde do Bom Retiro, sendo sucedido por João da Silva Carrão (18181888), que a ocupou de 1859 a 1881.

Carrão foi Deputado, presidente da Assembleia Provincial, governador da Província do Pará (1857-1858) e de São Paulo (18651866), ministro das finanças do gabinete do Marquês de Olinda. Segundo Hugon, era um catedrático de ensino claro e metódico. Sofreu influências de Bastiat e de Michel Chevalier, o que refletia otimismo na produção e no progresso técnico, além disso, era um entusiasta de Saint-Simon, Comte, Bazard e Enfantin. De influência saint-simoniana, Chavalier defendia o papel do estado em desenvolver grandes obras públicas. Essa influência, marcante nas aulas de economia política de Carrão, revelou-se de maneira decisiva na Economia Brasileira através, segundo Hugon, das grandes realizações de Irineu Evangelista de Souza.

Ainda, Carrão introduziu o autor inglês MacLeod em seus cursos ${ }^{135}$. Esta postura influenciou de forma importante a faculdade paulista. MacLeod era jurista e economista escocês e teve pouca expressão na Europa, por isso, podemos questionar se a sua presença no ensino brasileiro seria de influência europeia. Sua obra tem grande importância,

\footnotetext{
135 Segundo Gremaud (1997), Carrão foi o responsável pela tradução da obra Elementos
} de Economia Política de H. D. MacLeod em 1873. 
segundo Hugon: "estão, aliás, em perfeita consonância com o espírito do ensino da ciência econômica, no Brasil, correspondendo, também, ao estágio de desenvolvimento econômico do país, a esse tempo" (HUGON, 1957, p.358). MacLeod foi o primeiro economista britânico que destacou a natureza real do crédito e insistiu no papel representado pelos bancos na sua criação. Retoma ideias de Say e insiste na noção de criação de riqueza pela criação de utilidade. Estende essa noção no tempo e inclui à noção de utilidade a ideia de potencial.

Segundo Hugon, a sua presença no ensino brasileiro se justificaria por ser um jurista-economista como Carrão e Almeida Nogueira, além do mais, por dar destaque à ação dos bancos e do crédito como fator de produção, problemas estes que interessavam à economia brasileira de então. Ainda, insistia sempre na "consideração do futuro", o que fazia muito sentido para o clima econômico e psicológico dos "países novos", como o Brasil.

Para Gremaud,

\begin{abstract}
"Nesse sentido o pensamento brasileiro, desenvolvido junto às academias de direito, mantiveram, por meio de MacLeod, a tradição de buscar certas especificidades apropriadas aos problemas nacionais, fugindo de uma aceitação passiva do liberalismo desenvolvido pelos principais autores britânicos e mesmo franceses." (GREMAUD, 1997, p.55)
\end{abstract}

Carrão foi sucedido por Joaquim José Vieira de Carvalho, que ocupou a cadeira de 1881 a 1896. Carvalho viveu, durante sua cátedra, episódios e processos importantes da economia brasileira, como a imigração (em especial a italiana) e a abolição da escravatura. Estudou o pensamento econômico italiano, em especial, Antonio Ciccone e Luiggi Costa. O primeiro, neoliberal, influenciado também por MacLeod; o segundo, também um neoclássico.

A influência italiana continuará com seu sucessor, José Luis de Almeida Nogueira que, de 1896 a 1914, imprimiu ao ensino de economia 
uma expressão "mais científica". Além de professor, foi Deputado na Assembleia Constituinte, Deputado Federal e Senador Estadual, ademais, publicou a principal obra de referência para os cursos de Direito no estudo de Economia Política durante a República Velha, Curso Didático de Economia Política ou Ciência do Valor, de 1913. (GREMAUD, 1997)

Em tal obra, Nogueira sintetiza as principais influências que marcaram o ensino de economia na Faculdade de Direito de São Paulo, da escola clássica com Smith, Ricardo e Say, além de Bastiat e Stuart Mill, e as abordagens críticas de Chevalier e Sismondi, além disso, as ideias neoclássicas de Jevons, Menger, Walrás, Marshal e Pareto também estão presentes. A maior influência, entretanto, segundo afirma Gremaud, é de MacLeod $^{136}$. Seguindo o que já era uma característica da Economia Política no Brasil, há uma atenção importante à esfera da circulação, tendo como problemas centrais a questão comercial e monetária.

Para Hugon, a Faculdade de Direito de São Paulo, sobretudo a partir da docência de Almeida Nogueira, será uma Academia Macleodista. Amaury Gremaud resume bem a questão,

"o pensamento brasileiro, desenvolvido junto às academias de direito, mantiveram, por meio de MacLeod, a tradição de buscar certas especificidades apropriadas aos problemas nacionais, fugindo da aceitação passiva do liberalismo desenvolvido pelos principais autores britânicos e mesmo franceses.

Outro aspecto importante desta influência de MacLeod, que também está relacionada aos elementos acima apontados, são por um lado a centralidade que confere à circulação que, como vimos, é de longa tradição na Economia Política brasileira, por outro lado suas concepções acerca da moeda e do crédito parecem fazer deste autor escocês uma referência que bem se adequava às necessidades brasileiras de então". (GREMAUD, 1997, p.55)

\footnotetext{
${ }^{136}$ Para Gremaud (1997, p.49), a influência de MacLeod no ensino brasileiro tem seu ápice com Almeida Nogueira.
} 
Sintetizando, ainda que com características distintas e suas particularidades, as Faculdades de Direito de Olinda/Recife e de São Paulo refletem a forma como a Economia Política foi introduzida no Brasil, ou seja, irradiando e difundindo em grande parte o conhecimento clássico, mas preocupando-se de alguma forma com a especificidade e a realidade brasileira durante o século XIX. Isto se expressa, sobretudo, na preocupação com as questões monetárias, que podem ser apresentadas nos seguintes termos, segundo Gremaud, na escola pernambucana,

"Em termos monetários existe a concepção da necessidade de moedas fiduciárias com emissões feitas a partir de um sistema de pluralidade de bancos emissores particulares. Estas emissões, apesar de guardarem uma relação - a conversibilidade - com a moeda metálica, necessária à própria estabilidade de seu valor, tinham certos graus de liberdade em relação à quantidade de metais possuídos pelo Brasil já que não se exigia que tais emissões se fizessem acompanhando o estoque de moeda possuído pelo país". (GREMAUD, 1997, p.46)

Já na escola paulista, de maneira semelhante, "Em termos monetários vemos a penetração bastante forte de concepções mais atreladas às correntes anti-bullionistas ou à Escola Bancária, do que às posições de cunho ricardiano". (GREMAUD, 1997, p.55-56)

No final do século XIX, após a Proclamação da República, o ensino superior foi reformado e, a partir da introdução do ensino superior livre, diversas Faculdades de Direito foram criadas. O Ensino de Economia Política nos cursos jurídicos na Bahia, Ceará, Porto Alegre e em Ouro Preto são destacados de maneira resumida, tanto por Gremaud, quanto por Hugon e Nogueira de Paula, sem, entretanto, nenhum elemento que mereça maior menção diante do objeto ao qual nos propomos neste trabalho.

O Ensino de Economia Política nos cursos de Engenharia tem origem na Academia Militar, especificamente na Escola Central. O ensino civil 
separou-se do ensino militar com a criação de Escola Politécnica do Rio de Janeiro (que depois se tornou a Escola Nacional de Engenharia) em 1973, na qual a cadeira de Economia Política, Direito Administrativo e Estatística era oferecida no último ano do curso. (GREMAUD, 1997)

A primeira cátedra foi criada em 1864, tendo como titular José Maria da Silva Paranhos (1819-1880), Visconde do Rio Branco, até 1877. Senador, Conselheiro do Estado, Presidente da Província do Rio de Janeiro, Ministro do Brasil na Argentina, Uruguai e Paraguai, Ministro da Marinha, Ministro dos Estrangeiros e Ministro da Fazenda duas vezes entre 1861-1862 e 1871-1875, Rio Branco teve papel de destaque na política nacional. Seu curso seguia a linha do liberalismo clássico, apesar de rejeitar as conclusões liberais acerca do comércio internacional. Como ministro, em 1874, praticou uma tarifa comercial (conhecida como tarifa Rio Branco), taxando produtos estrangeiros ao mesmo tempo que previa isenção aos produtos necessários ao desenvolvimento industrial do país, facilitando a sua entrada. Para Hugon, "Aí está uma política comercial que atende às necessidades do progresso econômico do Brasil; corresponde uma doutrina intervencionista e industrialista, moderada, aliás, em sua aplicação." (Hugon, 1994, p.364) Dorival Vieira (1979-1981) concorda com a afirmação de Hugon e também enxerga em Paranhos uma orientação liberal porém industrialista moderada.

Já Gremaud (1997) acredita que não se deve exagerar na interpretação. Para tanto, argumenta que, apesar de não enxergar em Rio Branco uma visão liberal tradicional, acredita que sua atuação frente à política econômica teve orientação ortodoxa, assim como a sua famosa tarifa alfandegária de 1874 , que não teria sido tão protecionista assim. Desta forma, como Nícia Vilela Luz $^{137}$ em seu clássico livro sobre a industrialização, o autor argumenta que a tarifa refletia muito mais a influência do comércio no governo do que as próprias ideias de Paranhos. (GREMAUD, 1997, p.63)

${ }^{137}$ Luz, Nícia Vilela. A luta pela industrialização do Brasil. São Paulo: Alfa-Omega, 1975. 
Após Rio Branco, aponta Hugon, o ensino de Economia Política se desenvolve na Escola Politécnica, tendo, como finalidade, a situação da economia brasileira.

Luís Rafael Vieira Souto (1849-1922) ocupará, por concurso, a cadeira de 1880 a 1914, sendo seguido por Aarão Leal de Carvalho Reis, de 1914 a 1925 e Tobias Lacerda de Martins Moscoso, de 1925 a 1928.

Comum à formação dos três, a Engenharia, formação científica e matemática muito aprofundada. Assim como o Visconde do Rio Branco, catedrático de matemática na Escola Militar.

Portanto, isso nos dá uma visão muito prática. O país passava por transformações estruturais e estes homens lidavam com elas a todo momento. Isso os fazia refletir sobre as formas de como desenvolver o país, sua economia, sua indústria e sua infraestrutura.

Para Hugon,

"Esta formação de engenheiro os leva a uma atividade profissional em relação direta com os problemas da industrialização e da exploração das possibilidades econômicas do país. (...) Esses homens de cultura científica, profissional e diretamente em contato com as realizações econômicas, vão se encarregar, como professores, de lecionar economia política a futuros engenheiros, eles próprios com sólida formação científica. A ênfase recairá, portanto, sobre os problemas da produção e da circulação; dentre estes os da industrialização se destacarão com uma importância particular; está-se no período do verdadeiro surto inicial da indústria brasileira. $E$ necessidade de desenvolver uma indústria os leva a estudar as condições favoráveis a esse desenvolvimento: impõe-se antes mais uma política protecionista, que se corporifica na tarifa Rio Branco de 1873 , e se afirmará com as tarifas de Belisário e João Alfredo, de 1887 e 1888, acentuando-se, sob o regime republicano, com as tarifas Rui Barbosa, de 1890, e Murtinho, 1900." (HUGON, 1957, p.364-365) 
Esta postura protecionista era justificada, de uma lado, pelas próprias condições do país e, de outro, pela influência teórica das obras de List e de Carey. Para Hugon (1994), Vieira Souto, assim como Cairu, vai além dos limites fixados pelos liberais ingleses à intervenção do Estado na Economia. Inspira-se em List e Carey ao propor uma política comercial protecionista, contudo, assim como Carey, não seguirá List à risca e prefere crer que o desenvolvimento das forças produtivas de um país deve realizar-se dentro dos seus limites geográficos.

Vieira Souto era, portanto, um industrialista, defensor do protecionismo como forma de amparo e desenvolvimento da indústria, a qual considerava que não poderia sobreviver, desenvolver, tornar-se vigorosa e aperfeiçoada sem a proteção tarifária e cambial, que garantiriam, assim, o estímulo necessário ao progresso industrial.

"As considerações que temos feito, provam: 1) Que em
todos os países e especialmente países novos, como o
Brasil, que começam o seu tirocínio neste século, de
industrialismo adiantadíssimo, a grande indústria não
poderá viver, avigorar-se, desenvolver-se, aperfeiçoar-
se sem o protecionismo, pois sem a armadura das
taxas protetoras, a luta, que alguns pretendem a ser
um estímulo, só poderá reservar à indústria nacional o
sucesso que tiveram a esquadra espanhola enfrentando
a norte-americana e a russa combatendo a japonesa;
2) Que a proteção, para ser eficaz, deve ser franca, isto
é, dada com largueza suficiente para por a indústria ao
abrigo do dumping, assim como das grandes oscilações
cambiais e outras circunstâncias fortuitas, embora as
taxas não sejam exageradas até o proibitismo".
(VIERIA SOUTO apud BASTOS, 1952, P.52-53)

Ao defender o protecionismo, baseado na proteção aos bens aqui produzidos e que tinham similares importados a menores preços, argumentava também que o mesmo não prejudicaria os comerciantes vinculados à grande lavoura e que viviam dos ganhos com a exportação de gêneros, com a importação e o comércio dos bens importados. Na sua visão a proteção aduaneira contribuiria para o progresso não só da indústria, bem como da agricultura, ampliando assim o comércio interno. 
"Mesmo um parte mais esclarecida dos negociantes começa a convencer-se que a elevação das taxas aduaneiras, que recaem sobre generos similares, aos de produção nacional, beneficiando a lavoura e a indústria do país, não prejudicam o comércio; ao contrário, o desenvolvimento industrial e agrícola alarga o movimento comercial no interior, faz avultar as exportações e não diminui as importações, apenas transforma parte delas; o que se deixa de importar sob a forma de produtos acabados é compensado pelo excedente de matérias primas e acessórias que passam a entrar em maior quantidade". (VIERA SOUTO apud BASTOS, 1952, p.68)

Impressiona a lucidez e compreensão da realidade econômica e política internacional de Vieira Souto. Esta questão fica ainda mais clara quando defende que a indústria nacional, além dos dilemas relacionados a competitividade baseado nas tarifas internas, e percebe que a competição a nível internacional e a relação comercial com as nações desenvolvidas, envolve também elementos políticos e práticas monopolistas e de proteção de mercados, através da manipulação de preços possibilitada pelo poderio econômico e pela longa tradição industrial.

"todas as vezes que uma indústria nacional é criada no
país, fabricantes estrangeiros procuram matá-la, para
que não lhes escape o mercado onde eles tinham boa
freguesia, e para isso, baixam consideravelmente o
preço de seus produtos, o que Ihes é fácil porque são
fabricantes antigos e ricos, que exportam para toda
parte o que fabricam (...) porque o sacrifício será leve,
uma vez que os outros seus fregueses continuarão
assegurar-lhe lucros suficiente". (VIEIRA SOUTO apud
BASTOS, 1952, p.90)

Podemos perceber nas afirmações e ideias de Vieira Souto uma defesa incisiva da industrialização e uma crítica a vocação meramente agrária da economia brasileira e a uma suposta incapacidade de desenvolvimento industrial.

"Quem diz país novo diz industria nascente; portanto, a indústria que é criada em um país novo traz consigo a fraqueza de tudo que nasce ou começa (...) Se a condenação das denominadas indústrias artificiais 
pudesse prevalecer, nenhuma indústria poderia ser explorada no Brasil; ficaríamos reduzidos a grande indústria de torrefação de café, com lenha ou carvão nacional". (VIEIRA SOUTO apud BASTOS, 1952, p.133134)

No aspecto monetário e financeiro, as ideias de Vieira Souto refletem os acontecimentos da época, assim, se opunha ao ministro Joaquim Murtinho, sendo a favor da conversibilidade da moeda como forma para combater a inflação. Temia, tanto quanto a inflação, a insuficiência de meio circulante, numa clara referência a sua experiência de engenheiro em obras públicas onerosas, portanto, considerava a questão da inflação e da circulação monetária a partir das suas especificidades no Brasil. Todas estas questões remetem a um debate econômico importante no país, o debate entre metalistas e papelistas, que ainda será abordado neste capítulo.

Desse modo, Vieira Souto se destacou sobretudo em suas críticas à política econômica adotada por Campos Sales e Joaquim Murtinho. Nícia Vilela luz (1975) ressalta o seu vasto conhecimento da teoria econômica e sua postura crítica em relação à teoria quantitativa da moeda. Amaury Gremaud destaca a importância de suas obras ${ }^{138}$ e sua visão industrialista, chamando a atenção para o fato de que tal postura era também uma posição de interesse próprio, uma vez que possuía uma fábrica de fósforos. Aliás, tal questão oferece um bom reflexo do debate econômico-monetário no Brasil. De alguma forma, as posições políticas e econômicas sempre refletiram interesses de classes ou grupos sociais, sejam eles produtores rurais, exportadores, comerciantes ou industrialistas.

$138 \mathrm{O}$ autor, assim como Nogueira de Paula, lista as seguintes obras de Viera Souto: $A$ Situação Econômica de 1901, O último relatório da Fazenda de 1902, A Caixa de Conversão de 1906, Economia Política. Primeiro Volume. Introdução e Produção de 1916, Notes sur le Commerce International, la Navigation et les Finances du Brésil de 1917, A Produção Nacional e a Situação dos Mercados de 1919 e O Papel-moeda e o Câmbio de 1925. (NOGUEIRA DE PAULA, 1942, p. 31; GREMAUD, 1997, p. 62-63) 
Em trabalho recente, Maria Letícia Correa ${ }^{139}$ analisa a trajetória de Vieira Souto, relacionando a sua atuação como engenheiro e professor de Economia Política às transformações e ao início do processo de modernização urbana e industrial no Brasil no final do século XIX e início do XX, logo, conclui que o Ensino de Economia na Escola Politécnica teve um forte conteúdo prático, diretamente relacionado às necessidades do país.

"A consideração do ensino da cadeira de economia política praticado na Escola Politécnica do Rio de Janeiro na passagem do século XIX ao século XX, pela leitura do programa preparado por Vieira Souto e também do livro reunindo o conteúdo de suas aulas, faz com que seja necessário qualificar a interpretação, contida em certos memorialistas e mesmo em parte da produção acadêmica sobre o tema, segundo a qual a engenharia do período apresentava um caráter "enciclopédico" ou essencialmente "científico", por oposição a um almejado conteúdo voltado à "aplicação" que desse a devida ênfase às atividades relacionadas à tecnologia e às indústrias. $O$ que sugerimos é que a cadeira de economia política da escola, ao preocupar-se em estabelecer as distintas formas de inscrição dos engenheiros na modernização econômica, superava a perspectiva profissional, buscando garantir a esses profissionais seu papel como responsáveis pela elaboração de uma concepção integral do país, essencial tanto à expansão capitalista como à afirmação do Estado nacional, o que está na base na interseção entre a engenharia e a formação do campo da ciência econômica no Brasil. Não por acaso, a Escola Politécnica foi considerada como um dos primeiros centros de produção e difusão do pensamento econômico brasileiro". (CORREA, 2010, p.166)

Aarão Reis deu seguimento à linha de seu antecessor a partir de 1914 até 1925. Sua principal obra foi Economia Política, Finanças e Contabilidade, de 1918. Antes de ser catedrático, ganhou projeção em 1892 ao presidir a construção de Belo Horizonte. (GREMAUD, 1997)

\footnotetext{
139 CORREA, Maria Letícia. Engenharia, Economia Política e Progresso: a trajetória do engenheiro Luiz Rafael Vieira Souto como estudo de caso (1849-1922). Revista Brasileira de História da Ciência, Rio de Janeiro, v. 3, n. 2, p. 157-169, jul-dez 2010.
} 
Imaginava, para o país, uma política protecionista, moderada e provisória, que dependesse e variasse do estágio de desenvolvimento da nação. Influenciado por ideias de Comte e sant-simonistas, inclina-se para uma tendência sociológico-econômica, semelhante à do professor Aprígio Guimarães. (Hugon, 1994)

Aarão Reis foi sucedido por Tobias Lacerda de Martins Moscoso, que começou a dar ao curso de Economia uma nova orientação, apoiando o raciocínio econômico em demonstrações matemáticas e estatísticas, tendo sido para Hugon, um precursor neste campo no Brasil. Esta tendência continuará com seu sucessor, Jorge Filipe Kafuri, que dará ao curso um perfil mais aliado ao quadro moderno da economia racional.

Amaury Gremaud (1997) chama a atenção para a influência do positivismo, mas principalmente para as características intervencionistas e industrializantes mais acentuadas no ensino nas Escolas Politécnicas em relação às Faculdades de Direito. Além disso, podemos destacar a maior presença da matematização e formalização da análise, o que se deve ao contexto do curso de Engenharia. Para Gremaud, a diferenciação entre os dois ensinos marcará a diferença na formação dos cursos superiores em Economia posteriormente. Tem-se o contraste: cursos oriundos da Escola Politécnica do Rio de Janeiro, sob a influência mais prática e da formalização, e os de São Paulo, sob influência jurídica.

Assim sintetiza Gremaud,

"De modo geral, o ensino de Economia Política foi marcado pela influência do liberalismo clássico, variando entre as escolas francesa e inglesa. Porém não se ateve apenas a estas. Percebe-se também a influência de outras escolas de pensamento, de modo que a combinação destas diferentes escolas já é uma marca que confere alguma originalidade ao trabalho intelectual desenvolvido nos principais centros de formação do país. Outro aspecto relevante é a adaptação de muitas ideias estrangeiras à realidade nacional, denotando, da mesma forma que já ocorrera com Cairu, características mais intervencionistas ao 
pensamento nacional, apesar da prevalência do pensamento liberal." (GREMAUD, 1997, p.65)

Desta forma, destaca-se o poder de apropriação e adaptação da teoria econômica tradicional pelos catedráticos brasileiros do século XIX. Certamente, este recorte, de analisar o Pensamento Econômico Brasileiro a partir do ângulo do ensino de Economia Política, evidencia a originalidade de várias ideias concebidas aqui. Por outro lado, também podemos constatar o sentido prático que vários catedráticos davam às ideias econômicas. Muitos deles foram políticos e tiveram atuação importante. Isto, de certa forma, demonstra que o estudo e a compreensão do pensamento econômico brasileiro, durante o século XIX, faz sentido e é de fundamental importância para qualquer trabalho que vislumbre refletir sobre a formação e o desenvolvimento econômico nacional.

A análise do ensino de Economia Política no Brasil, durante o século XIX, consegue fornecer um espelho importante do Pensamento Econômico Brasileiro no período, isto é, um pensamento econômico que procurou sempre adaptar teorias econômicas dos países centrais. Conservadoras ou progressistas, poderíamos afirmar que tais adaptações não deixam de ser originais, afinal refletiam sobre a realidade brasileira.

\section{O Debate Monetário: papelistas x metalistas}

Sempre que invocamos a questão do pensamento econômico brasileiro, durante o século XIX, uma questão vem à mente: o debate acerca da política monetária no período imperial. Tal peleja ficou consagrada pela historiografia a partir da disputa entre metalistas e papelistas. Tal tema foi pano de fundo ou mesmo objeto de estudo para diversos trabalhos sobre o período imperial. Merece destaque aqui, pois representa o assunto central da discussão sobre a política econômica no século XIX, ainda, envolveu personagens políticos importantes, estudiosos da teoria econômica, muitos deles ministros da fazenda e por isso mesmo elaboradores ou gestores da política econômica. 
A denominação que dá título ao debate é uma criação posterior dos trabalhos que estudaram o tema. Hernán Sáez ${ }^{140}$ mostra, por exemplo, que não se pode afirmar que havia uma unidade entorno de duas únicas visões. Todas as posições que envolviam as questões monetárias e econômicas ilustram muito mais crenças políticas específicas e posições econômicas e sociais dos interlocutores do que propriamente a filiação a uma ou outra corrente. O termo, ou melhor, a classificação, papelista, inclusive, teria outra classificação correspondente: pluralista. Tal terminologia foi utilizada e esclarecida por Ana Maria Ribeiro de Andrade, ${ }^{141}$ em seu trabalho clássico sobre a questão.

Neste sentido, Sáez (2010), que também utiliza o termo pluralistas, questiona até mesmo a simples associação entre conservadores e metalistas, bem como entre liberais e papelistas, assim, a questão assume uma maior complexidade e envolve interesses dos mais variados, como dos latifundiários, agricultores, exportadores, importadores, negociantes, comerciantes, industriais, etc.

Contudo, apesar das generalizações contidas na terminologia e classificação consagrada pela historiografia, ela é razoável para que apresentemos não só as divergências que configuram o debate, bem como a apropriação que se fazia por aqui das teorias produzidas lá fora. Além de tudo, a querela monetária nos permite apreender a forma como se pensava a economia no país no século XIX.

O debate entre papelistas e metalistas refere-se diretamente ao debate, realizado principalmente no parlamento, entorno da política monetária durante o segundo reinado. Como afirmamos anteriormente, são muitos os estudos sobre o tema ou que o tiveram como pano de fundo. Por isso mesmo, procuraremos sintetizar seus aspectos mais

\footnotetext{
140 SÁEZ, Hernán Enrique Lara. Nas asas de Dédalo: um estudo sobre o meio circulante no Brasil entre os anos de 1840 a 1853. São Paulo:Humanitas, 2010.

${ }^{141}$ ANDRADE, Ana Maria Ribeiro de. 1864: A Controvérsia entre Metalistas e Pluralistas. Mestrado em História - Rio de Janeiro, UFRJ, 1987
} 
importantes e posicionar a questão no âmbito da História do Pensamento Econômico Brasileiro durante o século XIX.

Um dos trabalhos mais importante a abordar a questão é o de Heitor Ferreira Lima ${ }^{142}$. Sua perspectiva é condicionada pela discussão entorno do industrialismo e pela visão de que o liberalismo adotado no Brasil assumia uma forma conservadora do ponto de vista político. Para o autor, o contexto econômico brasileiro, da segunda metade do século XIX, marcado pela expansão do setor monetário da economia, exigia um grande volume de recursos materiais que o sistema bancário não podia atender. O debate entre papelistas e metalistas, em sua visão, envolvia sobretudo a solução deste problema, bem como espelhava o caráter conservador dos liberais brasileiros.

$\mathrm{Na}$ visão de Lima, prevaleceu o interesse da corrente metalista, ligada aos interesses da lavoura e dos exportadores, e que defendiam uma política de combate à inflação, estabilidade cambial e conversibilidade da moeda. O autor argumenta, também, que tal posição atendia ao interesse das finanças internacionais, especificamente a inglesa, ao manter o mercado nacional dependente da importação de artigos manufaturados, portanto, "nossos economistas e políticos liberais da época, impregnados do livre-cambismo, praticavam o puro conservadorismo dos grandes proprietários agrários".(LIMA, 1976, p.99100)

Dorival Teixeira Vieira ${ }^{143}$ aborda o tema ao estudar a evolução do sistema monetário no Brasil e procurou reconstituir os mecanismos monetários brasileiros até a década de 1940. Uma das preocupações centrais do trabalho é a instabilidade do sistema monetário brasileiro, que passou por diversas modificações no período, e a sua relação com o sistema produtivo, ademais, Vieira argumenta que os padrões monetários

142 LIMA, Heitor Ferreira. História do Pensamento Econômico no Brasil. São Paulo: Cia Ed. Nacional, 1976.

${ }^{143}$ VIEIRA, Dorival Teixeira. Evolução do Sistema Monetário Brasileiro. São Paulo: IPE/USP, 1981 
internacionais causaram enorme influência na organização do sistema monetário nacional, o que também se refletia na própria dicotomia entre metalistas e papelistas.

A influência do debate econômico internacional na contenda financeira brasileira, a partir de meados do século XIX, também é ressaltada por Flávio Saes, ${ }^{144}$ em seu clássico estudo sobre o sistema financeiro que envolveu a economia paulista no período.

A partir de outro enfoque, Ana Maria Ribeiro de Andrade ${ }^{145}$ analisa o debate entre metalistas e papelistas à luz da crise monetária de 1864, resultado da quebra da Casa Bancária Antônio José Alves do Souto \& Cia, situando-o no contexto monetário e financeiro do Segundo Império. Arilda Teixeira ${ }^{146}$, por sua vez, também aborda a polêmica ao discutir a política monetária no período.

A influência teórica na política econômica é o principal objeto da já bastante citada, aqui, tese de Amaury Gremaud, ${ }^{147}$ assim, o autor analisa e apresenta o debate monetário argumentando que este embasou toda a política monetária do período entre 1840 e 1930. Além de sistematizar a peleja, identificando sua origem e influências, discute também personagens e episódios mais marcantes da política monetária do período. Tais questões serão mais exploradas à frente. Sintetizando, Gremaud nos mostra que a questão monetária que envolvia metalistas e papelistas ilustra a influência da teoria econômica produzida na Europa no Brasil, bem a forma que ela foi apropriada, à luz da realidade brasileira, não só no debate, mas também na formulação e na condução da política econômica.

\footnotetext{
144 SAES, Flávio. Crédito e Bancos no desenvolvimento da Economia Paulista. 18501930). São Paulo: IPE-USP, 1986.

${ }^{145}$ ANDRADE, Ana Maria Ribeiro de. 1864: A Controvérsia entre Metalistas e Pluralistas. Mestrado em História - Rio de Janeiro, UFRJ, 1987.

${ }^{146}$ TEIXEIRA, Arilda C. Determinantes e Armadilhas da Política Monetária Brasileira no II Império. Dissertação de Mestrado, Niterói, UFF, 1991.

147 GREMAUD, Amaury Patrick. Das Controvérsias Teóricas à Política Econômica: pensamento econômico e economia brasileira no segundo império e na primeira república (1840-1930). Tese (Doutorado em Economia) - Universidade de São Paulo, 1997.
} 
Ao estudar o sistema monetário e bancário brasileiro, entre as décadas de 1850, 1860 e 1870, André Villela ${ }^{148}$ destaca o debate, argumentando que, durante o período, prevaleceram a moeda fiduciária e a conversibilidade e, o padrão-ouro, apesar de perseguido, fracassou. Contrariando e questionando a maior parte das interpretações a respeito das diferenças entre metalistas e papelistas, o autor acredita que ambos acabaram defendendo o padrão-ouro em nome da garantia de um ambiente macroeconômico de maior estabilidade.

Throughout most of the 1850-70 period Brazil operated a fiduciary system. In practice, convertibility was in force for less than a quarter of the time. Nevertheless, it was shown that most policymakers - even those, like Souza Franco, identified with liberal banking policies - supported adherence to the gold standard, a point ignored in the existing literature. This was then seen as the most effective means to ensure a stable macroeconomic environment. A fixed and, preferably, appreciated rate of exchange, would avoid income and wealth shifts, while it provided the sound money credentials that attracted foreign praise and capital. It was shown that despite Brazil's failure to adopt a goldbacked circulation during most of the period, monetary virtue was pursued almost relentlessly. Contemporaries, as noted by an observer, seemed indeed to have been for the most part "blind admirers of gold". And this blindness was shared by both metalistas and papelistas. (VILLELA, 2001, p.92)

Em sua tese de doutorado, recentemente publicada, Thiago Gambi $^{149}$ articula tal debate à criação e administração do segundo Banco do Brasil em 1853, dessa forma, tendo como pano de fundo a querela, o autor sustenta que a criação do banco está ligada ao projeto político

\footnotetext{
148 VILLELA, André. The Political Economy of Money and anking in Imperial Brazil 18501870. Doutorado em História Econômica - London School of Economics and Political Science, 1999; VILLELA, André. The Quest for Gold: Monetary Debates in Nineteenthcentury Brazil. Brazilian Journal of Political Economy, vol. 21, no 4 (84), OctoberDecember, 2001.

${ }^{149}$ GAMBI, Thiago. O banco da Ordem: política e finanças no Império brasileiro (18531866). 1. ed. São Paulo: Alameda/Fapesp, 2015; GAMBI, Thiago. O Debate Político e o Pensamento Econômico no Império brasileiro: centralização de poder e monopólio de emissão no segundo Banco do Brasil (1852-1853). Almanack. Guarulhos, n.09, p.176189, abril, 2015.
} 
centralizador saquarema que, em última instância, visava criar um Império forte nos trópicos e, para isso, acreditava ser vital uma moeda forte e lastreada, que contribuía para a manutenção da estrutura econômica e social brasileira sustentada na produção agrícola e no setor exportador.

Em outro trabalho recente, Hernan Saéz ${ }^{150}$ procura entender o meio circulante no Brasil em meados do século XIX. Para tanto, o autor analisou os discursos políticos sobre a moeda e o sistema bancário, concluindo que as elites políticas utilizaram seus conhecimentos de modo a elaborar soluções para os dilemas do processo de construção da nação.

Sáez opina que é preciso compreender o debate entre metalistas e pluralistas $^{151}$ à luz da vinculação dos seu partícipes a interesses econômicos concretos, bem como na crença que tais desígnios seriam o melhor caminho para a prosperidade nacional.

"O debate sobre a moeda permitiu apreender algumas das dinâmicas da realidade e as possíveis vinculações entre algumas atividades que estariam predominantemente ligadas ao mercado interno ou ao mercado externo. Essa vinculação estaria diretamente relacionada com as condições materiais da atividade dos agentes e os interesses econômicos daí provenientes. Não se tratava apenas de garantir simpatia às propostas que os favoreceriam, mas sim da formação de uma determinada leitura da realidade econômica de acordo com sua inserção na economia. (...) Assim, para além das filiações teóricas é preciso também analisar se e como os protagonistas do debate no Brasil estavam vinculados a determinados interesses econômicos concretos. A defesa da liberdade de emissão provincial atenderia, desta forma, alguns

\footnotetext{
150 SÁEZ, Hernán Enrique Lara. Nas Asas de Dédalo : um estudo sobre o meio circulante no Brasil entre os anos de 1840 a 1853. São Paulo:Humanitas, 2010. Em sua tese de doutorado, o autor analisa a formulação da política econômica entre 1850 e 1866 . ver SÁEZ, Hernán Enrique Lara. O Tonel Das Danaides: um estudo sobre o debate do meio circulante no Brasil entre os anos de 1850 a 1866 nas principais instâncias decisórias. Tese de Doutorado, História Econômica, FFLCH-USP, 2013.

${ }^{151} \mathrm{O}$ autor utiliza-se do termo pluralistas em referência à defesa da pluralidade de emissões, que os caracterizados aqui como papelistas defendiam. Para tanto se apoia no trabalho de Andrade (1987).
} 
interesses não necessariamente porque o deputado estivesse representando uma determinada classe econômica conscientemente, mas porque em sua crença a economia só poderia desenvolver-se se o governo permitisse que o mercado e seus agentes ajustassem as emissões às suas necessidades". (SÁEZ, 2010, p.62)

Ademais, se assemelhando a Villela (2001), questiona a associação automática entre conservadores e metalistas, liberais e pluralistas. Para o autor, ambos os lados estariam comprometidos com a unidade territorial, o que poderia significar certas concessões descentralizadoras, e com o crescimento econômico.

Portanto, estas posições não corresponderam às divisões partidárias tais como elas têm sido usualmente retratadas pela historiografia. Como mostraram o liberal Bernardo de Souza Franco ou o conservador Joaquim José Rodrigues Torres. Enquanto este último defendeu a provincialização, liberais como Souza Franco tenderam a combatê-la. Este fato permite questionar a visão clássica de conservadores como defensores da centralização e liberais defensores da descentralização. Ambos os grupos estavam comprometidos com a unidade territorial e admitiam algum grau de descentralização, de modo que suas posições não podem ser reduzidas à defesa de posições antagônicas uma vez que entendiam ser necessária a existência de um governo central forte o bastante para impor a unidade territorial e ambos compreendiam que este governo devia conviver com certo grau de autonomia provincial. Suas posições variavam, mantendo-se estas duas balizas, conforme o tema em questão. No caso do meio circulante os atores se dividiam conforme suas posições perante um debate que não era apenas brasileiro e conforme suas crenças nos instrumentos que consideravam mais adequados para preservar a unidade nacional e ao mesmo tempo promover o crescimento econômico. (SÁEZ, 2010, p.203) 
A partir de um enfoque bastante distinto em relação aos trabalhos discutidos anteriormente, Pedro Dutra Fonseca ${ }^{152}$ refere-se à querela como precursora do debate acerca do desenvolvimento econômico no Brasil. Para o autor, os papelistas, de pensamento mais prático que teórico, com a finalidade e os olhos voltados para a expansão da economia e dos negócios, seriam um dos precursores do desenvolvimentismo no país.

A partir de uma abordagem focada na discussão do episódio que ficou conhecido como Encilhamento, outros trabalhos ${ }^{153}$ também exploram o embate entre metalistas e papelistas, de forma a dar suporte à análise da crise especulativa que marcou o início da primeira República no final do século XIX. Tais trabalhos costumam evidenciar a atuação do papelista Ruy Barbosa como ministro da Fazenda, ao praticar o pluriemissionismo e o incentivo consequente ao crédito, que gerou um ambiente de intensa especulação no mercado de capitais e deu origem ao colapso financeiro amplamente conhecido. Ainda, apesar da crise, trabalhos como o de Maria Bárbara Levy ressaltam a importância do período no fomento ainda que embrionário de diversas indústrias no país, além disso, tal episódio sempre é descrito e analisado em conjunto com a atuação posterior do metalista Joaquim Murtinho como Ministro da Fazenda na renegociação das dívidas do governo e no programa de estabilização conhecido como Funding Loan durante o governo de Campos Sales.

Mas do que se trata tal peleja efetivamente?

Impossível abordar a questão sem fazer referência ao importante debate na teoria econômica sobre a questão monetária, envolvendo

\footnotetext{
152 FONSECA, Pedro Cezar Dutra. A Controvérsia entre Papelismo e Metalismo e a Gênese do Desenvolvimentismo no Brasil. In: Anais do XXXVI Encontro Nacional de Economia da ANPEC, Salvador, 2008; FONSECA, Pedro Cezar Dutra; MOLLO, Maria de Lourdes Rollemberg. Metalistas x Papelistas: origens teóricas e antecedentes do debate entre monetaristas e desenvolvimentistas. Nova Economia, Belo Horizonte, 22(2), p.203-233, maio-agosto, 2012.

153 Destacamos o texto clássico de Maria Bárbara Levy. Ver LEVY, Maria Bárbara. O Encilhamento. In: NEUHAUS, Paulo (coord.). Economia brasileira. Uma visão histórica. Rio de Janeiro: Ed. Campus, 1980.
} 
figuras da envergadura de Henry Thornton, Thomas Tooke, John Fullerrton, David Ricardo, Robert Peel e John McCulloch. Os três primeiros, representantes da Escola Bancária e, os últimos, representantes da Escola Monetária. Por trás deste debate, encontramos posições diversas acerca das emissões monetárias e conversibilidade da moeda, bem como as preocupações com a inflação e a ampliação da atividade econômica ${ }^{154}$. Segundo Mollo (1994), as duas escolas concordavam em dois aspectos importantes, relacionados com o longo prazo, "a determinação do valor da moeda pelo custo de produção do ouro e a aceitação, por ambas as escolas, de que a conversibilidade-ouro das notas bancárias era fundamental para dar estabilidade à economia". (MOLLO, 1994, p.86).

Apesar disso, as duas correntes divergiam nas análises a respeito do curto prazo. Sinteticamente, a Escola Monetária (ou Currency School), guiada pelo princípio monetário, acreditava, assim como previa a teoria quantitativa da moeda, que o aumento da oferta de moeda gerava inflação, dessa forma, a diminuição da oferta de moeda levaria, também, à redução da inflação. É o que bem sistematiza Mollo (1994),

"A Currency School aceitava a TQM, segundo a qual a direção de causalidade na identidade $M V=P Y$ vai de $M$, que é a quantidade de moeda, para $P$, que é o nível geral de preços, uma vez que a velocidade de circulação, V, é suposta constante, e o produto real, $Y$, é suposto não ser afetado pelas variáveis monetárias, ou por M. Assim, o controle estrito da quantidade de moeda é pregado como fundamental para o bom funcionamento da economia, evitando flutuações de preços que acentuariam as tendências para os booms e as crises.

Como o pensamento liberal dos pensadores da Currency School não admitia o poder interventor do Estado para limitar a oferta monetária, os limites propostos para a emissão eram os que se relacionavam com o padrão-ouro, ou seja, pregavam a adequabilidade de um sistema que respeitasse uma

${ }^{154}$ MOLLO, Maria de Lourdes Rollemberg. As controvérsias Monetárias do Século XIX. Ensaios FEE, Porto Alegre, 15-1, 1994 e Fonseca \& Mollo (2012). 
regra automática, como a do sistema-ouro, mesmo que se tratasse de um sistema misto, como o vigente na época, onde circulavam ouro e notas bancárias. Surgia, então, o Currency Principie, segundo o qual a quantidade de moeda em circulação deveria crescer sempre que houvesse entrada de ouro no país e deveria cair se houvesse saída de ouro para o Exterior." (MOLLO, 1994, p.87)

Já a Escola Bancária (ou Banking School) acreditava no princípio bancário, que afirmava que notas bancárias seriam emitidas para efetivar operações de crédito que davam como garantias transações comerciais já realizadas, portanto, a emissão bancária corresponderia a uma contrapartida real e, assim, refletiria um incremento das transações comerciais; logo, se o excesso de moeda metálica ou de emissões de papel moeda representavam um risco inflacionário, a emissão de notas bancárias não, dado que refletia diretamente o volume de transações comerciais. Para a Escola Bancária, deste modo, as notas bancárias deveriam ser diferenciadas da moeda metálica e do papel moeda corrente. É o que bem esclarece Gambi (2015),

"O chamado princípio bancário dava o norte da escola bancária. Tal princípio sustentava que notas bancárias só eram emitidas para efetivar operações de crédito que tinham como contrapartida transações comerciais já realizadas. Ora, se a emissão bancária tinha contrapartida real, ela não podia provocar inflação. Seu aumento nada mais era do que reflexo do aumento das transações comerciais. Este sim podia ou não provocar inflação. Portanto, segundo esse princípio, o sentido da causalidade vai da transação comercial (preço) para a emissão (oferta monetária) e não o contrário. Transações comerciais e emissão de notas bancárias funcionavam como duas faces de uma mesma moeda.

Enquanto a profusão de moeda metálica e a emissão de papel-moeda poderiam gerar inflação, a emissão de notas bancárias não correria o risco de produzir tal resultado, uma vez que apenas acompanhava o ritmo das transações comerciais já realizadas. O aumento da emissão de notas bancárias seria apenas indicador de um aumento das transações ou dos preços. Por isso, a escola bancária sustentava que, na questão monetária, as notas bancárias deviam 
ser diferenciadas da moeda metálica e do papel-moeda corrente." (Gambi, 2010, p.85).

Como apontam Gremaud (1997) e Sáez (1986), o debate monetário inglês era uma referência para o debate brasileiro, assim, as ideias e a política econômica brasileira eram influenciadas por tais argumentos. Contudo, apesar de manter suas características básicas, levavam em conta as peculiaridades e particularidades da economia brasileira oitocentista. Consequentemente, diante de uma sociedade escravocrata como a brasileira, em meados do século XIX, o debate sobre a política monetária ganhava aspectos especificamente brasileiros, sem deixar de reproduzir, no essencial, o debate britânico.

Ainda com relação à adaptação das teorias à realidade brasileira, Hernán Sáez (2013) indica que nem sempre os debatedores e pensadores brasileiros chegavam a conclusões que estivessem de acordo com as proposições dos teóricos que liam, estudavam e citavam, logo, argumenta o autor, "por diversas vezes é possível perceber que as teorias europeias serviam apenas como um referencial para problemas concretos existentes na economia nacional". (SÁEZ, 2013, p.49)

A questão central que se colocava à economia brasileira durante o século XIX era a monetária. A produção cafeeira se dinamizava crescentemente, o que ia aumentando e intensificando o uso do dinheiro. Esta situação era acompanhada de certa limitação do sistema bancário e de crédito, bem como de um intenso debate sobre a emissão monetária. É entorno destas questões que se organiza a peleja entre metalistas e papelistas.

Para Heitor Ferreira Lima, tal debate refletia os contornos conservadores do liberalismo brasileiro, ou dito de outra forma, refletia como a "sociedade brasileira de então fundava-se numa estrutura agrário escravocrata, ferrenhamente defendida pelos conservadores, com apoio 
tácito ou declarado dos liberais" (LIMA, 1976, p.92). Para o autor, o debate envolvia unidade ou pluralismo bancário, isto é, monoemissionismo ou pluriemissionismo e consistiu no principal problema da política econômica brasileira na época.

Portanto, o debate entre metalistas e papelistas relacionava-se ao meio circulante e à organização do sistema financeiro. Não havia uma clara homogeneidade entre as ideias dos diferentes membros das duas correntes, entretanto, é possível organizar os principais argumentos. Resumidamente, os metalistas defendiam a moeda com padrão metálico, enquanto os papelistas, uma moeda que guardasse uma relação mais fraca com tal padrão, portanto, uma moeda fiduciária. (Gremaud, 1997:85).

Entre os metalistas, para citar alguns, podemos destacar Joaquim José Rodrigues Torres (o Visconde de Itaboraí), Torres Homem, Teixeira Junior e Silva Ferraz. Já entre os papelistas, podemos mencionar Irineu Evangelista de Souza (Visconde de Mauá), Bernardo de Souza Franco, José Pedro Dias de Carvalho, Francisco de Paula Santos, Dantas, Paranaguá, Saraiva, entre outros ${ }^{155}$.

A corrente metalista tinha a taxa de câmbio como a sua principal preocupação, por isso, acreditava que a quantidade de moeda em circulação deveria ser responsável pela manutenção de sua estabilidade e, assim, o meio circulante deveria ser totalmente lastreado em metal, no entanto, havia na economia brasileira, durante o século XIX, grande carência de metais que lastreassem a moeda. Portanto, como mostra Gambi (2015), apesar de, na teoria, os metalistas acreditarem na necessidade de manter o lastro metálico da moeda, no governo sempre encontravam uma alternativa para que a escassez metálica não paralisasse as transações comerciais.

155 TEIXEIRA, Arilda C. Determinantes e Armadilhas da Política Monetária Brasileira no II Império. (Dissertação de Mestrado), Niterói, UFF, 1991. 
Para Gambi (2015), o que pautava o pensamento e ação dos metalistas era a preocupação com a estabilidade cambial. Seus representantes, geralmente, tinham ligações com os setores agrários exportadores da economia brasileira oitocentista, por isso, o câmbio e tudo que influísse no setor externo da economia condicionavam suas ideias e ações. Logo, pelo princípio bancário, a oferta de moeda estava relacionada à inflação e, portanto, ao câmbio. A taxa de câmbio seria determinada, desse modo, pela quantidade de moeda em circulação e, por consequência, determinaria a necessidade de ajuste nesta taxa. Qualquer excesso na quantidade moeda, em relação ao ritmo de negócios, desvalorizaria o câmbio, sinalizando a necessidade de intervenção para diminuição da oferta de moeda. O importante era a manutenção da estabilidade cambial, o que atendia aos interesses dos setores exportadores da economia, assim, para os metalistas, o câmbio tinha maior importância que a taxa de juros, que assumia papel secundário nas suas preocupações, sendo determinada pelo mercado através das flutuações de oferta e demanda.

Já os papelistas se preocupavam com o giro dos negócios, portanto, para eles, a taxa de juros tinha um papel central na economia, por isso, propunham que a quantidade de moeda em circulação deveria garantir a realização das transações comerciais. Admitiam, dessa forma, a possibilidade do meio circulante ser ou não lastreado em metal (ou seja, uma relação mais fraca entre moeda e metal), uma vez que a escassez de metal, geralmente, era uma condicionante e atrapalhava a economia brasileira. Isto, por outro lado, não significava que fossem contra conversibilidade da moeda em metal, apenas admitiam uma relação mais frouxa e um lastro em títulos da dívida pública quando houvesse escassez de metal, assim, a oferta de moeda deveria ser determinada pela demanda de moeda para transações e, se o aumento da oferta monetária fosse acompanhado pelo incremento no volume de transações, não haveria motivo para desvalorização da moeda nacional. (GAMBI, 2015) 
Com base no princípio bancário, seria o volume das transações que determinaria as emissões de notas bancárias. A correspondência entre emissão e transação indicaria que o problema do excesso de emissão não existiria e, caso existisse, o excesso de demanda por notas bancárias levaria a um aumento da taxa de juros e, assim, ao ajuste da emissão; como consequência, a taxa de juros ocuparia um papel central na visão papelista, sendo a variável de ajuste da oferta de moeda. Dessa forma, os papelistas acreditavam que a melhor maneira de atender a demanda por moeda, suprir a necessidade dos negócios e assegurar a melhor distribuição do meio circulante nas praças comerciais, seria a pluralidade emissora através de bancos privados. (GAMBI, 2015) Sintetizando, nas palavra de Gremaud,

"A preocupação básica da corrente papelista é o estado dos negócios, o nível interno de atividade, mais do que a estabilidade cambial.

Assim defende-se para o Brasil a moeda fiduciária, mesmo porque não existe metal suficiente para garantir as transações do país. Mesmo que haja um lastro metálico para a moeda, a sua emissão não precisa seguir a evolução quantitativa do lastro metálico. A oferta de moeda deve ser ditada pela variação da demanda por moeda e o principal elemento desta demanda é o volume de transações. Para atender a esta "receita" nada melhor que a diversidade de bancos emissores, estes têm maior capacidade de saber sobre a demanda." (GREMAUD, 1997, p.87).

Notamos, portanto, que tais preocupações evidenciam os interesses dos setores da sociedade ligados ao setor interno da economia, ou seja, à produção de gêneros de consumo interno e ao comércio. É o que bem argumenta Thiago Gambi,

"Tais preocupações revelam os interesses de frações da classe dominante ligadas mais ao setor interno do que externo da economia. Daí a preocupação secundária com a taxa de câmbio, resultante, para os papelistas, do movimento da balança comercial. De fato, numa economia mercantil e escravista como a brasileira, o câmbio estava sempre sujeito à instabilidade porque 
seu valor dependia dos preços e das condições de demanda por produtos nativos no mercado externo, como bem apontou Furtado." (GAMBI, 2015, p.88)

Portanto, a peleja entre metalistas e papelistas ocupou um lugar importante no debate de ideias econômicas no Brasil durante o século XIX, além disso, foi alvo também de intensos debates políticos no parlamento. Este debate moveu e embasou os rumos de boa parte da política econômica brasileira durante o período imperial e a primeira república. E foi, portanto, um aspecto fundamental na gênese do Pensamento Econômico Brasileiro.

Entre os diversos personagens que atuaram ativamente neste debate, vamos destacar, daqui para a frente, as ideias econômicas de três deles: Joaquim José Rodrigues Torres, o Visconde de Itaboraí, tido como metalista, e Bernardo de Souza Franco e Irineu Evangelista de Souza, o Visconde de Mauá, representantes do papelismo, sendo o primeiro moderado e o segundo radical. Desde já alertamos que tal opção se deve sobretudo à representatividade das suas ideias para o conjunto e ilustração da discussão, ainda, cabe ainda justificar o porquê de não incluirmos, na análise, o nome das figuras proeminentes de Ruy Barbosa e Joaquim Murtinho. Trata-se, sobretudo, de uma opção de periodização. Da mesma forma que procedemos com Azeredo Coutinho, cujas ideias não representavam a realidade e o contexto de transição do mundo lusobrasileiro, as ideias de Barbosa e Murtinho são frequentemente identificadas com o período republicano e ilustram a transição do século XIX para o XX, período da modernização capitalista do Brasil.

Um dos mais importantes políticos do Império, líder e referência nas questões econômicas entre os conservadores; assim podemos classificar Joaquim José Rodrigues Torres, o Visconde de Itaboraí. Nascido em São João de Itaboraí em 1802, faleceu no Rio de Janeiro em 1872, tem sido uma das figuras de maior destaque na política do segundo Império. Estudou matemática em Coimbra e, após retornar ao Brasil, lecionou na 
Academia Militar. Ocupou, por diversas vezes, diversos Ministérios, tendo se destacado, sobretudo, na Fazenda, cargo que ocupou por diversas oportunidades, além disso foi deputado, senador e presidente da Província do Rio de Janeiro. No campo político, iniciou a sua trajetória como liberal, tendo se tornado conservador em 1837 e, como tal, tornou-se a referência do partido nas questões econômicas.

Nícia Vilela $L^{156}$ o caracteriza como nacionalista, defensor de medidas que favorecessem a liberdade, a prosperidade e independência do país e temeroso com a "vulnerabilidade de um país exclusivamente agrícola e na estreita dependência dos mercados estrangeiros". (LUZ, 1978, p.26) Segundo a autora Rodrigues Torres, questionava, dessa forma, a vocação eminentemente agrária brasileira na produção de "matérias brutas ou gêneros, que não aceitam consumo senão nos mercados estrangeiros". (Rodrigues Torres, apud Luz, 1978, p.26) Contudo, aponta Luz, adotava certa cautela na adoção de uma política protecionista, uma vez que não queria contradizer os interesses agrícolas e, diante do dilema de promover a indústria, cuja necessidade reconhecia como fundamental, e atender os interesses dos agricultores, evitou a defesa e a adoção de uma política protecionista.

Suas ideias econômicas estão alinhadas à corrente metalista do debate monetário, entretanto, Suzigan e Pelaez alertam que sua posição poderia ser tida como intermediária, uma vez que "suas ideias constituem um dos enfoques mais ecléticos de política econômica e um esforço pragmático de conciliar os objetivos de decisão política da intermediação com os da estabilização". (SUZIGAN; PELAEZ, 1981, p.72)

Assim, a partir da questão levantada por Luz, Suzigan \& Pelaez (1981, p.75) afirmam que "Itaboraí e seus seguidores acreditavam que todos os casos de industrialização bem sucedidos baseavam-se em certa forma de protecionismo", o que indicaria uma visão liberal adaptada ou

${ }^{156}$ LUZ, Nícia Vilela. A Luta pela Industrialização do Brasil. São Paulo: Ed. Alfa Omega, 1978. 
moderada, fortemente apoiada na crença de que um "liberalismo modificado" poderia significar industrialização, progresso e prosperidade a longo prazo. As ideias de Rodrigues Torres, neste aspecto, poderiam ser sintetizadas da seguinte forma,

"Uma das diferenças entre o pensamento de Itaboraí e o da ortodoxia metalista dizia respeito à análise da industrialização e do crescimento. Discordava veementemente da liberdade total do comércio exterior e da atividade econômica. O Governo deveria tentar diversificar as atividades econômicas para evitar a dependência dos mercados estrangeiros e, assim, evitar as flutuações periódicas que impediam o crescimento econômico acelerado. De acordo com seu pensamento, os países agrícolas cresciam mais devagar do que os industriais. Assim, dever-se-ia tentar a substituição de importações de bens industriais de consumo. Com base numa forma incipiente do argumento da indústria nascente, defendia um protecionismo moderado. Mas também advertia sobre os efeitos negativos da autossuficiência. As medidas protecionistas deveriam ser somente temporárias e os critérios de eficiência a longo prazo deveriam ser implementados quando possíveis". (SUZIGAN; PELAEZ, 1981, p.75)

No que diz respeito à mesma questão, Thiago Gambi ${ }^{157}$ argumenta que,

\begin{abstract}
"Além disso, no relatório de 1849, Rodrigues Torres escreve a seção "Meios de proteger a indústria". Nela, posiciona-se claramente contra a liberdade ilimitada de comércio e indústria, e defende o fomento e a proteção a indústrias nacionais que pudessem produzir de modo mais eficiente produtos que eram importados. No entanto, também deixa claro que o estímulo à indústria teria que ser limitado e cauteloso, a fim de não impor demasiado custo e sacrifício à indústria agrícola. A proteção da indústria manufatureira e fabril nacional deveria ser combinada com os interesses da agricultura. Rodrigues Torres não deixava de falar sobre a importância do crédito, do comércio e da
\end{abstract}

157 GAMBI, Thiago. Pensamento Econômico na Periferia: um esboço das ideias econômicas de Joaquim José Rodrigues Torres (1848-1858). In: IV ESHET - Latin American Conference, Cedeplar-UFMG, Belo Horizonte, 2014. Ver também Gambi (2015). 
manufatura para o país, mas era no fundo um defensor da moeda e dos interesses agrícolas." (GAMBI, 2014, p.18)

Tal característica é vista por Gambi como um aspecto fundamental do pensamento econômico de Itaboraí: a adaptação de certos preceitos ortodoxos de política monetária à realidade brasileira. Apesar de se inspirar na escola monetária inglesa, não assimilava a teoria de forma passiva, adaptando-a ao contexto nacional afim de que fosse viável do ponto de vista da política econômica. Tal interpretação é compartilhada por Sáez (2010). Acrescentaríamos à tal avaliação, inspirados na caracterização que Ricardo Bielschowsky estabelece para Eugênio Gudin, "liberal convicto, mas atento" 158.

Em uma mesma linha, Hernán Sáez (2010) aponta que, por vezes, Rodrigues Torres adotava posições contradizentes à sua categorização como conservador, ou mesmo metalista e, que seria um equívoco atribuir a ele posições e ideias mecânicas em relação a crenças teóricas.

Além de tudo, é preciso levar em conta outros fatores na análise, principalmente a posição social e os interesses políticos e econômicos que envolviam suas posições. Neste sentido, é preciso esclarecer que Itaboraí era casado com a filha de um cafeicultor fluminense e suas ideias, na maioria das vezes, estavam diretamente relacionadas aos interesses deste setor exportador.

Para Gambi, contudo, as principais características das ideias de Rodrigues Torres eram inspiradas na escola monetária, defendendo assim a estabilidade monetária, seja por confiança na teoria quantitativa da moeda, seja pela crença de que o fortalecimento do Império passaria pela necessidade de um meio circulante forte.

\footnotetext{
158 Tal caracterização se apoia na perspectiva que Gudin teria adaptado a visão tradicional do livre-cambismo e da teoria econômica neoclássica " à realidade de país "reflexo" do Brasil (como o mesmo gostava de caracterizar o país em vez de utilizar o termo subdesenvolvido). BIELSCHOWSKY, Ricardo. Eugênio Gudin. In: SZMRECSÁNYI, Tamás; COELHO, Francisco da Silva (Orgs.). Ensaios de História do Pensamento Econômico no Brasil Contemporâneo. São Paulo: Atlas, 2007.
} 
"As ideias econômicas de Rodrigues Torres tomarão o caminho da escola monetária inglesa. Uma de suas principais preocupações era a manutenção do valor do meio circulante, seja por uma questão doutrinária, pois aceitava a teoria quantitativa da moeda, seja por uma questão política, pois era preciso garantir uma moeda estável ao império brasileiro. Suas ideias estão muito relacionadas à questão da moeda e do crédito. Defendia o monopólio de emissão de notas em uma grande instituição bancária, que poderia ser pública ou privada, mas sempre supervisionada pelo governo dado o caráter público da emissão. Seu caráter público se revelaria nas consequências do aumento da oferta monetária para a economia como um todo. A conversibilidade em metal era uma exigência. A princípio, o meio circulante deveria ser lastreado exclusivamente em ouro, mas Rodrigues Torres terá que se render à realidade da economia brasileira e, na prática, admitir também a conversibilidade em notas emitidas pelo governo". (GAMBI, 2014, p.11)

Outra característica de seu pensamento foi a defesa da centralização bancária, evidentemente contrário à pluralidade bancária defendida pelos papelistas, como forma de controle monetário e estabilidade do valor do papel-moeda. (GREMAUD, 1997, p.92)

O que caracterizaria o caráter adaptativo de suas ideias seria a não radicalização do ideal metalista, que se fez presente em diversas das suas ações, seja na criação do Banco do Brasil, de 1853, seja na sua atuação como Ministro da Fazenda, assim, fez concessões no que diz respeito à necessidade de manter a conversibilidade da moeda de maneira muito estreita. Adaptando seus ideais à realidade, acreditava não ser possível a aplicação fiel da teoria à realidade nacional, uma vez que a quantidade de moeda em circulação dependia das características específicas de cada economia. (GAMBI, 2014)

Desta forma, as ideias de Rodrigues Torres ilustram as características principais do pensamento econômico brasileiro do século XIX. Essencialmente, Itaboraí foi um metalista, porém, atento à realidade, 
conformou seu pensamento e prática aos limites que a estrutura econômica nacional impunham, em nome do projeto político conservador.

Entre os interlocutores mais críticos às ideias do Visconde de Itaboraí está Bernardo de Souza Franco. Natural de Belém, nasceu em 1805, tendo falecido em 1875. Teve longa trajetória e carreira política, tendo sido Ministro da Fazenda, Conselheiro de Estado, Deputado, Senador e Presidente de Província. De inclinação liberal, é associado à corrente papelista, tendo publicado ${ }^{159}$ o clássico Os bancos do Brasil, ${ }^{160}$ de 1848, uma referência no debate monetário, especialmente a respeito da pluralidade das emissões monetárias e da organização do sistema monetário brasileiro.

"Grande eclético" foi a forma como Octávio Gouveia de Bulhões \& Carlos Manuel Peláez ${ }^{161}$ o caracterizaram. Já Suzigan \& Peláez (1981, p.87) argumentam que o seu livro era um dos melhores sobre política econômica do seu tempo, apontando-o como um dos mais proeminentes economistas brasileiros da época.

Seu diagnóstico sobre a economia do Império, segundo Thiago Gambi (2015), apontava que os juros altos, o curto prazo dos empréstimos, e a escassez do meio circulante eram os principais problemas econômicos enfrentados pelo Brasil. Os juros altos estariam ligados ao descompasso entre a demanda (muito alta) e a oferta (muito baixa) por capital que, por sua vez, estariam ligados à desorganização das instituições de crédito no país. Já o prazo dos empréstimos, não atendiam os interesses industriais, que não poderiam ser atendidos pelo crédito comercial, deste modo, acreditava que a solução estaria no estímulo à criação de instituições financeiras de crédito de longo prazo como os bancos hipotecários. Quanto ao caso do meio circulante, defendia que o

${ }^{159}$ Além do trabalho clássico publicou também A Situação Econômica e Financeira do Brasil em 1863.

160 SOUZA FRANCO, Bernardo. Os Bancos do Brasil. Brasília, Ed. UnB, 1983.

161 BULHÕES, Octávio Gouvêa de; PELÁEZ, Carlos Manuel. Introdução a Propósito da Intermediação Financeira. In: SOUZA FRANCO, Bernardo. Os Bancos do Brasil. Brasília, Ed. UnB, 1983. 
mercado fosse livre para suprir a carência através dos bancos privados. Defendia, consequentemente, a pluralidade de emissão, portanto, os problemas e suas soluções estariam articulados entorno da questão creditícia e bancária.

Assim, os Bancos tinham um papel central no pensamento de Souza Franco; como intermediários financeiros, seriam a chave do progresso como bem mostram Bulhões e Peláez (1983, p.4). Haveria, então, uma estreita ligação entre os bancos e o sistema monetário, sendo que a criação de bancos estaria diretamente relacionada ao desenvolvimento da economia nacional. (GAMBI, 2015, p.261)

Um dos principais problemas da economia brasileira, na visão de Souza Franco, como mostra Gremaud (1997), seria a falta de metais e o prejuízo que tal problema causava para a indústria, logo, as instituições de crédito seriam "o mais poderoso meio de aproveitar os capitais desempregados, pô-los a serviço da indústria, e como que os duplicara em seu benefício". (SOUZA FRANCO, 1983, p.9) Neste aspecto, Gambi (2015, p.261) o caracteriza como "defensor do crédito em primeiro lugar" e "um fervoroso defensor dos bancos de emissão".

Ainda abordando os bancos, Gremaud (1997) aponta que Souza Franco acreditava que eles tinham um caráter dual, tendo ao mesmo tempo caráter privado, cujo sentido seria o lucro, e caráter público, uma vez que "eles fornecem instrumentos de circulação e de crédito fundamentais ao desenvolvimento do país, principalmente de um país como o Brasil, onde a falta de metais é uma característica marcante". (GREMAUD, 1997, p.89)

Portanto, novamente com relação aos bancos, Sáez (2010) indica que "Bernardo de Souza Franco lidou com a ideia da formação de um sistema bancário privado e autônomo que se desenvolveria livremente nas localidades onde os capitais dormentes conseguissem se organizar". (SÁEZ, 2010, p.102) 
Logo,

\begin{abstract}
"Ele concebia os bancos como instituições capazes de reunir acionistas em busca de valorização para seus capitais por meio do crédito. Assim, essas instituições colocavam à disposição de investidores capitais que, do contrário, permaneceriam dormentes nos cofres e colchões de seus proprietários. Ao cumprir a função de mediador entre poupadores e investidores, os bancos poderiam coadjuvar ou contrariar governos no desenvolvimento da riqueza pública e na administração do meio circulante, fornecendo-o na medida da necessidade dos mercados e conservando-o, ao mesmo tempo, o mais fixo e invariável possível". (GAMBI, 2015, p.260)
\end{abstract}

Nas questões relativas ao padrão monetário, defendia a moeda metálica, contudo, acreditava que, diante da dificuldade que esta representava para a sustentação do crédito, bem como para o seu transporte e manuseio, defendia a moeda fiduciária, cuja necessidade se impunha ao desenvolvimento econômico. Nas suas palavras, "A moeda metálica dificulta a sustentação de estabelecimentos de crédito, que tão necessários são aos países industriosos". (SOUZA FRANCO, 1983, p.8788)

Para Souza Franco, as moedas emitidas pelo setor bancário seriam preferíveis em relação ao papel-moeda emitido pelo Estado que, além de não terem lastro, não se adequariam à demanda de mercado temporal e geograficamente, dessa maneira, defendia o pluriemissionismo, não só como forma de enfrentar as enormes distâncias que separam o território nacional, bem como para resolver a escassez de crédito na economia brasileira. (GREMAUD, 1997, p.90)Apesar disso, como aponta Gambi (2015), também se preocupava com a estabilidade da moeda e, assim, não defendia uma moeda totalmente sem lastro e a instabilidade em seu valor como forma de aumento do crédito.

Percebemos, portanto, que as ideias de Souza Franco se caracterizam, sobretudo, pela defesa de uma política econômica favorável 
à ampliação dos negócios internos através da ampliação do crédito e da circulação monetária. Era, assim sendo, um representante da corrente papelista, mas, como já mencionado anteriormente, era tido como um moderado, sobretudo no que diz respeito à relação entre a conversibilidade e a estabilidade monetária. Neste sentido, um papelista radical e ferrenho defensor da moeda fiduciária foi Irineu Evangelista de Souza, o Visconde de Mauá.

Nascido no Rio Grande do Sul, próximo à fronteira com o Uruguai, em 1813, Irineu Evangelista de Sousa, Barão e depois Visconde de Mauá, foi um dos personagens mais importantes do período imperial brasileiro. Desembarcou no Rio de Janeiro em 1822, sem instrução ou o auxílio de parentes, trabalhou como caixeiro em uma loja comercial. Autodidata, estudou inglês, francês, contabilidade e diversas outras matérias, tendo ingressado em uma firma inglesa aos 16 anos e se tornado sócio da mesma aos 23. Fez fortuna no comércio, do qual abriu mão para se dedicar à indústria. Entre as décadas de 1840 e 1870, quando foi à falência, empreendeu, participou e foi dono de diversas industrias, fundou bancos, construiu ferrovias, iluminou a cidade do Rio de Janeiro, estabeleceu a ligação telegráfica com a Europa, entre outras atividades. Certamente uma das figuras mais marcantes de nossa história, Mauá já foi alvo de diversos estudos e interpretações.

Inevitável é a comparação de sua trajetória com a própria trajetória política e econômica do segundo reinado. Do auge ao declínio, do declínio à falência, em meados da década de 1870, a vida e os seus negócios espelham também o apogeu do II Império, entre as décadas de 1840 e 1860, e sua crise, a partir dos anos 70 do século XIX. Diversos são os trabalhos que tentam interpretar a sua vida, ação e obra.

Variados são os trabalhos que procuram valorizar 0 perfil empreendedor de Mauá, tido, por muitos, como o primeiro grande empresário brasileiro. Em 2013, comemorou-se o bicentenário de seu 
nascimento, tendo sido foco de uma coletânea ${ }^{162}$ de artigos que procuram valorizar esta característica empreendedora e empresarial do movimento de sua história.

Na mesma onda de celebrações, mas com foco mais abrangente de toda a trajetória de Mauá, Ceci Juruá ${ }^{163}$ procura fornecer uma síntese dos trabalhos a seu respeito, organizando sua obra de modo a entender os obstáculos por ele enfrentados ao longo dos tempos.

Entre os trabalhos clássicos sobre Mauá, destaca-se os de Heitor Ferreira Lima ${ }^{164}$, para quem Irineu Evangelista de Sousa foi um legítimo homem de negócios, um capitalista que "com sua obra, com suas realizações, cuja evidência não pode ser negada, ele personificou uma das aspirações do tempo, a aspiração capitalista, que encerrava então o ideal mais avançado". (LIMA, 1976b, p.27)

Valorizando, assim, a figura pessoal e as realizações de Irineu Evangelista de Sousa, Heitor Ferreira Lima procura interpretar a sua decadência, atribuindo-a à uma relação ruim com o Imperador e o poder imperial e ao boicote do capital internacional. Em resumo, trata-se de entender a crise dos seus negócios como resultado imposto por um boicote de forças políticas internas e externas que teriam seus interesses ameaçados por Mauá. Linha parecida segue Lídia Besouchet ${ }^{165}$ em Mauá e seu tempo, para quem Irineu Evangelista foi a maior figura do Império, um progressista, emancipador, pioneiro da indústria e cuja decadência estaria fortemente relacionada a fatores externos. Do mesmo modo,

\footnotetext{
162 SOUZA, Ricardo Timm de; FOSSATTI, Nelson Costa (orgs.). Mauá: paradoxos de um visionário. Porto Alegre: Letra\&Vida, 2013.

163 JURUÁ, Ceci. Irineu Evangelista de Sousa, Barão e Visconde de Mauá: defensor do nacionalismo econômico do Oiapoque ao Chuí. Rio de Janeiro: Jardim Objeto, 2013.

164 LIMA, Heitor, Ferreira. 3 Industrialistas brasileiros: Mauá, Rui Barbosa, Roberto Simonsen, São Paulo: Alfa-Omega, 1976b. Ver também Lima (1976).

${ }^{165}$ BESOUCHET, Lídia. Mauá e Seu Tempo. Rio de Janeiro: Ed. Nova Fronteira, 1978.
} 
segue Jair Ribeiro da Silva, ao caracterizá-lo como predestinado, fundador do Liberalismo Econômico Brasileiro. ${ }^{166}$

Uma referência mais contemporânea sobre Mauá é o importante trabalho de Jorge Caldeira ${ }^{167}$, Mauá: empresário do império. Um misto de biografia, romance histórico e história política e social, o livro expõe em parte uma visão romantizada da trajetória de Mauá, alçando-o à condição de herói e buscando vilões para as seus insucessos e frustrações. Neste caso específico, devemos destacar a presença até certo ponto exagerada de Rodrigues Torres (cujas ideias discutimos acima) como grande vilão da decadência dos seus negócios.

Tais julgamentos nos parecem um tanto quanto exagerados. Carlos Gabriel Guimarães ${ }^{168}$ explora esta questão, mostrando que certo mito de herói injustiçado foi construído nas interpretações a respeito de Mauá. Logo,

"quando se trata da economia brasileira do século XIX, enfatiza no "primeiro surto industrial" verificado no Brasil na segunda metade do mesmo século, mais especificamente no período 18501875, graças ao "industrial nacionalista" Irineu Evangelista de Souza, o Visconde de Mauá. O "Imperialismo" inglês e a falta de apoio de um Estado subordinado aos interesses dos barões do café fizeram com que o "industrial" Mauá falisse com a crise econômica de 1875 e, com isto, chegara ao fim a Era Mauá. Nada se falou da ligação do Visconde de Mauá com os ingleses, muito menos da sua ligação, como diretor da firma inglesa, com traficantes de escravos como Manuel Pinto da Fonseca, como também com o próprio Estado Imperial, com suas ligações de amizade e de negócios com membros dos partidos Conservador e Liberal". (GUIMARÃES, 2012, p.34)

166 SILVA, Jair Ribeiro da. Mauá em Face da Economia Nacional. São Paulo: Rumo Gráfica Ed., 1983.

167 CALDEIRA, Jorge. Mauá: Empresário do Império. Rio de Janeiro: Companhia das Letras, 1995.

168 GUIMARÃES, Carlos Gabriel. A PRESENÇA INGLESA NAS FINANÇAS E NO COMÉRCIO NO BRASIL IMPERIAL: os casos da sociedade bancária Mauá, MacGregor \& Cia. (18541866) e da firma inglesa Samuel Phillips \& Cia. (1808-1840). São Paulo: Alameda, 2012. 
Interpretação semelhante, porém mais conciliadora, é a de Flávio Saes ${ }^{169}$, para quem a trajetória de Mauá está ligada ao desenvolvimento da economia brasileira durante o período imperial, assim, o insucesso de Irineu Evangelista, cujas atividades empresariais tentavam enunciar um certo tipo de modernidade capitalista, estariam muito mais vinculadas às características e à própria crise da economia escravista exportadora brasileira do que a qualquer tipo de perseguição à sua figura como supõe certa parte da historiografia.

Afirma Saes que surtos industriais no Brasil no século XIX foram bloqueados, antes de tudo, pela incapacidade de uma economia escravista de engendrar um mercado interno e uma modernização capitalista que the dessem suporte, logo, Mauá, antes de ser uma vítima do Estado imperial e do capital estrangeiro, com eles construiu seu império e sua derrocada também está relacionada à própria crise, que culminou no fim do regime imperial.

"É inegável que o sucesso dos negócios de Mauá dependia de uma estrutura econômica e social nãoescravista, assim como é certo que alguns de seus empreendimentos podem ter ferido interesses estrangeiros. Não nos parece, no entanto, que Mauá fosse um adversário do regime imperial (mesmo quando se declarava contra ao escravismo) e um inimigo do capital inglês (mesmo quando se queixava de seus prejuízos junto àqueles capitalistas). (...) por um lado, a existência de vínculos entre Mauá e o Império (que lhe concede os títulos de barão e de visconde) e entre Mauá e o capital inglês (a quem teria recorrido várias vezes), embora sua falência estivesse ligada aos problemas causados pelo governo imperial e pelo capital inglês". (SAES, 1987, p.104)

Desta forma, a trajetória de Mauá seria nada mais do que um reflexo dos dilemas da nossa própria economia. Para Flávio Saes, Mauá e suas empresas merecem destaque na História Econômica do Brasil e "sua imagem como pioneiro da indústria e da ferrovia no Brasil, faz inteira

169 SAES, Flávio. Mauá e Sua Presença na Economia Brasileira do Século XIX. In: Barão de Mauá. Empresário e Político. Rio de Janeiro: Bianchi Ed., 1987. 
justiça diante do conjunto de empreendimentos levados à frente por Mauá durante algumas décadas do nosso século XIX". (SAES, 1987, p.105)

Não é do nosso interesse explorar tão detalhadamente as interpretações mais gerais da vida e da obra do Visconde de Mauá. No que há de específico para nosso trabalho, procuramos entender de alguma forma as ideias econômicas de Irineu Evangelista de Sousa. Tal objeto talvez não tenha o devido destaque na historiografia a ele referente.

Ao analisar os seus escritos, mais especificamente, $O$ Meio Circulante do Brasil, fica claro que estamos diante de um profundo conhecedor dos clássicos da Economia Política, como Smith e Ricardo, que não aceitou tais postulados integralmente, tendo tentado adaptá-los à realidade brasileira da época; ou, nas palavras de Heitor Ferreira Lima,

"Trata-se, com efeito, de eminente economista
dedicado aos assuntos nacionais, com toda seriedade,
buscando soluções condizentes com nossos melhores
interesses, desapegado das teorias clássicas,
inconvenientes para nós, mas prestigiosas entre
técnicos e políticos, como se fossem doutrinas eternas,
de validade universal e inabaláveis". (LIMA, 1976,
p.117)

Um dos grandes méritos da leitura econômica de Mauá é a adaptação que procede dela à realidade nacional. Percebendo que as condições na qual foi concebida diferiam muito do contexto brasileiro, rejeita categoricamente a teoria clássica da moeda, propondo algo original, próprio, factível à nossa condição.

"Conhecedor aprofundado da realidade brasileira, não seguia as teorias econômicas liberais alienígenas, apesar de muito difundidas, por julgá-las impraticáveis entre nós, prejudiciais aos nossos interesses e por contribuírem para manter a estagnação vigente. Tal percepção provinha-lhe da avaliação justa das necessidades de que padecíamos e das capacidades latentes inaproveitadas que possuíamos (...) Mauá não aceitou as teorias dos clássicos nas questões monetárias, por julgá-las inadequadas às nossas condições, elaboradas em outros lugares e 
desvinculadas de nossa realidade(...) Sua observação e atuação prática indicavam-Ihe caminho diferente, apresentando, em vista disso, concepções próprias". (LIMA, 1976, p.112 e 114)

Enquanto de forma um pouco exagerada, Lima enxerga em O Meio Circulante do Brasil um tratado de economia monetária ${ }^{170}$, Amaury Gremaud o classifica como um panfleto, cujo principal objetivo era a defesa da moeda sem lastro metálico e da ideia de que o câmbio e as emissões não estavam correlacionadas. (GREMAUD, 1997, p.97)

De maneira sintética, poderíamos resumir as ideias de Mauá da seguinte forma: negando a teoria clássica da moeda, defendia a liberdade do crédito com o intuito de expandir a produção e o comércio; propunha emissões em papel inconversível com o sentido de promover recursos para o desenvolvimento, incentivando o aparecimento e a expansão de empresas; refutava a ideia de que as emissões influenciavam no câmbio, cuja explicação estaria nas flutuações de sua oferta e demanda, naquele momento específico resultado da deficiência das colheitas, estagnação das exportações, da depreciação desses produtos nos mercados consumidores e da importação excessiva; defendia a emergência de um verdadeiro mercado de capitais no Brasil, com a intenção de diminuir a dependência estrangeira que resultava em juros altos; acreditava na pluralidade das emissões monetárias.

Ao defender a moeda sem lastro metálico, Gremaud (1997) aponta que Mauá ia além das propostas de Souza Franco, que tinha a moeda metálica como parte do lastro para as emissões bancárias, e afastava-se do princípio bancário inglês, que via na conversão metálica e na concorrência bancária uma forma de evitar o excesso de emissões. Assim, para ele, o controle das emissões seria resultado do equilíbrio de mercado

\footnotetext{
${ }^{170}$ Santiago Fernandes também apresenta interpretação bastante entusiasmada do escrito de Mauá. Seu trabalho tem o inegável mérito de analisar as ideias de Mauá à luz da perspectiva da adaptação das teorias à realidade nacional. Ver FERNANDES, Santiago. Mauá, o Economista do Império. Análise de sua crítica científica ao padrão-ouro. Revista Brasileira de Economia, Rio de Janeiro, 28 (2):3-28, abr./jun., 1974.
} 
e do conhecimento dos agentes. Gremaud chama atenção ainda para a proposição dos "bancos emitirem com base em um lastro composto por títulos públicos, o que traria a vantagem de retirar do mercado financeiro a concorrência do governo, possibilitando o aumento da massa de meio circulante e diminuindo a taxa de juros". (GREMAUD, 1997, p.100)

Mas e o que diz o próprio Mauá? É o que tentaremos expor a seguir, a partir de $O$ Meio Circulante do Brasil, que foi originalmente publicado em 1878, em uma série de artigos que Mauá, assinando simplesmente com a inicial V., escreveu no Jornal do Comércio em abril do mesmo ano, sob o título Questões Econômicas - A Situação Monetária do Brasil. ${ }^{171}$

A grande questão econômica do Brasil, para Irineu Evangelista de Sousa, era a monetária. Para ele, a economia política e a teoria monetária dela derivada não se adequavam à realidade brasileira e às necessidades que esta impunha sobre o meio circulante.

"O que têm dito e escrito os grandes mestres da ciência econômica não nos constrange e nem nos assustam as doutrinas por eles apregoadas, elevadas à categoria de axiomas, tratando-se de moeda.

A teoria da moeda é, pois, viciosa, economicamente falando, e não responde à questão que pretende resolver". (MAUÁ, 1976b, p. 41)

Logo no início do texto, o autor já indica o teor de sua crítica à teoria econômica, questionando o fato dela não conseguir se impor como ciência pelo fato de não ter efetividade de forma universal. Desta colocação de Mauá, podemos supor que o Irineu Evangelista tem uma certa visão mecânica das ciências sociais e da sua pretensa tentativa de ser universal. Por outro lado, é preciso contextualizar as suas observações que, apesar de demonstrar certo conhecimento filosófico e metodológico, como aponta Fernandes (1974), por exemplo, tem o objetivo mais claro de contrapor as doutrinas econômicas à realidade brasileira.

${ }^{171}$ MAUÁ, Irineu Evangelista de Sousa. O Meio Circulante do Brasil. In: LIMA, Heitor, Ferreira. 3 Industrialistas brasileiros: Mauá, Rui Barbosa, Roberto Simonsen, São Paulo: Alfa-Omega, 1976b 
"A economia política, que pretende explicar esses fenômenos, abrange em sua amplidão toda a esfera da atividade humana; é forçoso, entretanto, reconhecer quem, conforme o ponto de vista sob que estão estudados os fatos econômicos, encontram-se problemas de solução difícil, ainda mesmo para os espíritos mais refletidos, que procuram chegar a conclusões seguras. É, com efeito, sabido que, antes que uma teoria consiga firmar-se na sólida base da ciência, tem de pôr à prova as suas conclusões, que devem ser invariáveis em todos os países e em qualquer ocasião; de outro modo perde a teoria aquela base, vendo-se substituída pelos ditames da força das circunstâncias, mesmo eventuais, que aconselham a adoção de certas medidas na vida financeira e econômica de países em que o desvio de pretendidos axiomas econômicos torna-se proveitosa aplicação prática.

E, na verdade, cumpre estar prevenido contra certas ideias apregoadas com dogmática severidade por parte de doutrinários inflexíveis, as quais nem sempre são aplicáveis a países onde as causas que determinam certos fenômenos são diversas, e portanto o regime aconselhado como salvador de altos interesses para uns daria em resultado ficarem estes seriamente comprometidos em outros, se o bom-senso nacional não repelisse o presente grego, que os chamados mestres da ciência lhe querem impôr". (MAUÁ, 1976b, p.38)

E continua, desta vez com um grau menos condenatório em relação a economia política, a partir do fato de que esta tem a necessidade de lidar com diversas questões e realidades distintas e, muitas vezes, pretende explicar problemas com generalizações impróprias. O que expõe a necessidade de rever certos postulados diante de outros contextos ou desconsiderá-los diante de sua inadequação.

"O estudo da economia política é difícil pelas variantes que abrange, e pelas circunstâncias essencialmente diversas até onde pretende estender essa ciência a influência de seus princípios, querendo seus apóstolos dominar fatos que ainda não podem explicar. Isto 
provoca resistências que, sem condenar a ciência, desautorizam alguns de seus dogmas, como outros de igual pretensão já o foram, e denuncia a necessidade de maior estudo quanto a origem de certo fatos em controvérsia, ou talvez a necessidade de expulsar do seu vasto arsenal científico mais de uma pretensão insustentável." (MAUÁ, 1976b, p. 39)

Em outro momento, coloca a questão de forma mais clara. Não se trata de abandonar os princípios econômicos, o que seria "navegar sem bússola", mas adaptá-los às especificidades do Brasil, uma vez que, diante das circunstâncias, não conseguiriam explicar a nossa realidade.

"não poremos à margem os princípios econômicos, pois reconhecemos que isso seria navegar sem bussola. Temos em vista, porém, aplicá-los às circunstâncias especiais do nosso país sendo para nós evidente que algumas de suas teorias ou não suportam a pressão dos fatos que nos são relativos, ou têm estes de ser explicados de forma a introduzir mais um anel na cadeia científica, cuja força é impossível reconhecer". (MAUÁ, 1976b, p. 41)

Diante de todo o exposto, aponta a ciência monetária como o ramo de maior divergência entre os economistas e começa a esboçar o que será marcante em toda a sua análise, o meio circulante através das emissões bancárias sem lastro como o motor da economia.

"Se a moeda, e os bilhetes de banco conversíveis à vontade dos portadores constituem o motor por excelência das transações monetárias de qualquer país, porquanto esse tipo comparativo do valor não constitui unicamente ordens à vista sobre o capital do país que Ihe dá circulação, mas tem a vantagem de ser aceito para o mesmo fim pelo valor convencional que seu cunho lhe empresta, em toda a parte, aonde o comércio tem estendido a sua ação civilizadora, o que, na verdade, nada deixa a desejar. Não se segue que essas condições superlativas de um ótimo meio circulante, dos países que possuem amplos recursos para mantê-las, não possam ser substituídas, com vantagem, com grande vantagem mesmo, pelo papel não convertível temporariamente de bancos de inteiro crédito, de grande capital, que, forçados pelas circunstâncias especiais de qualquer país, se vejam 
compelidos a conservar em sua carteira, em vez de ouro, títulos particulares de bom crédito e do Estado, representando suas notas em circulação.

Em última análise, como é visto e sabido, os metais preciosos escolhidos de preferência para servirem de motor às transações, são apenas mercadoria sobre a qual, devido à essa aplicação especial, a lei econômica da oferta e a demanda atua com maior intensidade, em circunstâncias dadas. Produz-se então demanda excepcional, que determina violento abalo às transações, depreciação geral de todos os valores, e consequentemente perdas enormes, e não só no próprio país que sofre imediatamente os efeitos da crise, porém ainda (si se trata de um grande centro comercial) fazendo suportar as mesmas ou maiores contorções, a outros países com quem se ache relacional. Quem há aí tão pouco lido na história financeira do mundo que não aponte o dedo até as datas em que os terríveis efeitos dessas crises se fizeram sentir no mundo comercial? E no entanto, os exagerados apóstolos da escola metálica fecham os olhos a essa imensa nomenclatura de desastres, que deram em resultado perdas reais, do mais estupendo alcance, e também a transferência injusta de muitas fortunas de umas para outras mãos, sempre em vantagem das grandes fortunas, que nessas ocasiões, como regra, absorvem as médias e mínimas, envolvidas nos maiores esforços da atividade industrial". (MAUÁ, 1976b, p.40)

O Visconde de Mauá se colocava como um grande defensor do liberalismo e por isso mesmo buscava vincular o problema monetário à questão. Para ele, o mercado monetário, assim como todos os outros, deveriam ser livres e funcionar de acordo com a lei da oferta e da demanda. Por isso, apregoava a pluralidade de emissão dos bancos que seriam regulados pelo livre funcionamento do mercado.

"O verdadeiro tipo do valor, assim da moeda como de quaisquer outros objetos, é a oferta e a demanda, tipo por sua natureza variável, porém nem por isso menos bem fundido, pois tem o cunho da ciência. É verdadeiro em todos os tempos, e em qualquer ocasião, desde que se achar firmado no regime financeiro de qualquer país - grande princípio da liberdade das transações; princípio salutar, que tem de ser adotado em todos os 
países em que prevalecer o regime de liberdade, seja qual for a forma de governo, ou o mecanismo político pelo qual se procure garantir, de modo mais eficaz, os direitos individuais, base fundamental de toda boa organização social". (MAUÁ, 1976b, p. 41)

Ele justifica a defesa do princípio de liberdade das transações e a pluralidade de emissões nas necessidades de progresso da economia. Sua exposição não apresenta medida concreta de controle do processo, mas sugere que a experiência prática dos agentes de mercado solucionaria o problema, o que nos parece uma das posições menos bem fundamentadas que apresenta.

"A criação da riqueza dispensa uma fórmula que a verdadeira lei natural científica não reconhece.

Os países que aspiram a ocupar lugar conspícuo no grêmio das nações civilizadas não podem, porém, dispensar instrumentos de permuta, adequados às exigências de sua vida econômica, financeira e administrativa: determinar, porém, o quantum e a qualidade dos instrumentos que devem satisfazer a essas necessidades é simplesmente impossível, pois não há estudo que o possa conseguir, sendo tão variadas e complicadas as causas que atuam para dar força ao princípio da desigualdade, elemento fecundo de todo o progresso, pois dele nasce a emulação, que obra com imensa força sobre as artérias que funcionam para por em movimento todos os elementos de atividade humana. (...)O meio circulante é pois a condição vital para o movimento que opera a troca, ou compra e venda do excedente da produção de cada um, em relação ao seu consumo, que representa essa imensa riqueza, sempre no mercado sujeita à lei da oferta e da demanda, que Ihe determina o valor: sem essa transmissão a criação da riqueza não pode ter lugar." (MAUÁ, 1976b, p.44)

Sobre o meio circulante, portanto, sintetiza assim a questão da emissão e da conversibilidade,

"Nós sustentamos deliberadamente que a grande lei econômica, da oferta e demanda - tudo nivela em relação ao valor venal dos objetos, bem como em relação aos serviços remuneráveis, e essa lei atua com 
a mesma força, quer a circulação se componha de espécies metálicas, quer seja mista, quer exclusivamente representada por um papel-moeda inconvertível". (MAUÁ, 1976b, p.44)

Acreditava, dessa forma, na moeda fiduciária, que em última instância seria garantida pelo governo. Expondo, portanto, a sua visão da questão monetária de que é o meio circulante a força motora das transações e da economia e não somente uma representação de valor como queriam os economistas clássicos. Logo,

"o erro nasce da falsa ideia, aliás apregoada por alguns economistas de nota, que a moeda e ainda os papeis de crédito representam as transações em cuja liquidação intervém, quando são meramente a força motriz que atua para a sua realização". (MAUÁ, 1976b, p. 46)

Mauá finaliza o seu trabalho argumentando que a moeda inconversível sempre teria sido utilizada na economia brasileira e que, graças a isto, deve-se o desenvolvimento, progresso industrial e comercial do país. Assim,

"O papel inconvertível de que se serve o nosso país há mais de meio século, realizando exclusivamente com ele as transações que suas necessidades, 0 desenvolvimento de seus recursos naturais, e o seu progresso industrial e comercial têm reclamado, desde a compra das verduras nos mercados, até as mais altas operações financeiras, não pode deixar de ser reconhecido e apreciado como um instrumento de permutas benéfico, pois sem ele, só fazendo sacrifícios talvez desproporcionados às nossas forças, teríamos dominado as dificuldades que a natureza das cousas impõe à inexperiência, tratando-se de fundar e organizar uma sociedade nova, e ainda tendo-se presente as contrariedades de caráter especial que interpuseram sua influência.

A esse papel se prende toda a vida econômica e financeira do Brasil.

Tem sido ele, o regulador da circulação de todos os valores, que representam a riqueza em nossa terra". (MAUÁ, 1976b, p. 47) 
Trata-se, portanto, de reconhecer em Irineu Evangelista de Sousa, para além das avaliações que tentam o elevar a categoria de herói nacional pelos seus feitos empresariais e perfil empreendedor, com certo exagero diga-se, um pensador brilhante, que, diante da realidade brasileira e dos problemas práticos da sua vida como comerciante e empresário, bem como de um conhecimento aguçado e curioso dos clássicos da Economia Política produziu uma leitura original e criativa da realidade econômica brasileira. 


\section{Conclusão}

Procuramos, ao longo desta tese, discutir o Pensamento Econômico Brasileiro no século XIX, com base na perspectiva que entende a História consciência crítica da experiência social da humanidade, valorizando a relação dialógica entre a História e a Economia, entre a teoria e a História. Para tanto, foi fundamental entender como se interpreta o país, suas raízes, formação, desde suas heranças aos elementos culturais e à questão das ideias, além disso, foi necessário um esforço teóricometodológico que justificasse e impusesse nosso objeto como tema de pesquisa coerente, possível e fundamental à História.

No primeiro capítulo, discutimos a herança ibérica, as interpretações do Brasil e a sua relação com a formação das ideias e a formação do Brasil. Procuramos estabelecer uma relação entre a discussão política e a econômica, entre os elementos que marcam a formação da identidade, da cultura, da política e a formação do pensamento econômico no Brasil.

Percebemos que a herança ibérica nos impõe um outro tipo de matriz civilizatória, ou de cultura, avessa aos ideais individualistas e maximizadores do mundo moderno, nos quais o liberalismo se apoia. 0 caso do pensamento político brasileiro nos parece singular. Toda discussão se origina a partir da formação e consolidação da nação no século XIX, partindo da discussão de como tais ideias se apropriam do liberalismo, bem como têm uma influência decisiva de nossa herança ibérica e colonial. Nos capítulos seguintes analisamos o pensamento econômico sob perspectiva semelhante.

Colocadas as questões iniciais, buscamos compreender 0 pensamento econômico do ponto de vista teórico e metodológico. Discutimos, dessa forma, no segundo capítulo, a condição de existência de pensamentos econômicos nacionais. Tal discussão passou necessariamente por uma crítica à suposta pretensão universalizante da teoria econômica neoclássica e a afirmação de que a economia, ciência 
social que é, não pode prescindir da história em suas postulações. O resultado disso são pensamentos econômicos nacionais que se apoiam nas especificidades e características de cada país na sua elaboração.

Outra questão que se apresentou como fundamental foi a difusão das ideias econômicas em escala internacional. Do ponto de vista da periferia do capitalismo, na maioria das vezes o Pensamento Econômico se caracterizou pela apropriação e adaptação das teorias que foram produzidas no centro. Tais apropriações e adaptações seriam caracterizadas pela originalidade ao adaptar ideias e conceitos às realidades históricas distintas das quais foram produzidas.

Com base nestes aspectos, definimos o Pensamento Econômico Brasileiro, constatando que sua principal característica é a forma prática que assume. Diante dos nossos problemas e dilemas, a reflexão econômica sempre foi mais voltada à ação do que à teoria, com algumas exceções, evidentemente, como é o caso de Celso Furtado, por exemplo.

A partir de preocupações que envolvem o desenvolvimento, o subdesenvolvimento e a industrialização, a maior parte dos estudos sobre o Pensamento Econômico Brasileiro concentrou seus esforços em entender o século $\mathrm{XX}$, ignorando indiretamente a possibilidade de considerar outros períodos de nossa história.

Sem desconsiderar a importância e a centralidade das discussões que envolvem 0 século $X X$ e a problemática específica do desenvolvimento, afirmamos a necessidade e a possibilidade de abordagem do Pensamento Econômico no século XIX.

Dessa forma, no terceiro capítulo, organizamos e sistematizamos o que consideramos e propomos ser o Pensamento Econômico Brasileiro. Iniciando a discussão com a análise das ideias e da obra de José da Silva Lisboa, por considerar que suas visões ilustram bem o mundo lusobrasileiro em transformação no início do século XIX, especificamente após a vida da coroa portuguesa para o Brasil e o consequente rompimento dos 
laços coloniais. A análise dos trabalhos que comentaram a obra de Cairu, bem com a própria análise dos seus escritos, nos levaram a constatação que suas ideias não só difundiram a Economia Política no Brasil, como refletiram as principais características econômicas do país no período, assim como expõe um pensamento econômico original e uma interpretação da realidade brasileira.

Em seguida, discutimos o ensino de Economia Política no país, durante o século XIX, a partir das Faculdades de Direito e Engenharia. A análise do perfil dos lentes responsáveis pela cadeira nos respectivos cursos, bem como do conteúdo oficial no qual apoiavam o ensino, nos mostra como a Economia Política se difundiu pelo Brasil, bem como evidencia um perfil que, apesar de tradicional, tinha certos aspectos de ecletismo que estavam diretamente relacionados às especificidades e necessidades reais de nossa economia e estrutura. Destacamos, desta forma, o poder de apropriação e adaptação da teoria econômica tradicional pelos catedráticos brasileiros do século XIX, evidenciando a originalidade de várias ideias concebidas aqui. Podemos constatar, por outro lado, também, o sentido prático que vários catedráticos imprimiam às ideias econômicas, o que se relaciona diretamente com a posição que ocupavam na sociedade brasileira, seja como políticos, seja como responsáveis por grandes obras e transformações da infraestrutura econômica nacional. A análise do ensino de Economia Política no Brasil, durante o século XIX, consegue fornecer um espelho importante do pensamento econômico brasileiro no período. Isto é, um pensamento econômico que procurou sempre adaptar teorias econômicas dos países centrais. Conservadora ou progressista, poderíamos afirmar que tais adaptações não deixam ser originais, afinal refletiam sobre a realidade brasileira.

Por fim apresentamos o debate monetário entre papelistas e metalistas, aspecto fundamental da discussão a respeito da política econômica no período. O debate entre as duas correntes evidencia como a 
discussão econômica no Brasil era sustentada pela apropriação de teorias e ideias produzidas nos países centrais. Neste caso, trata-se, sobretudo, da influência inglesa e o debate monetário entre Escola Monetária e Escola Bancária. À luz da realidade brasileira, a peleja ganhou aspectos e características próprias que evidenciavam a sua adaptação e adequação às nossas especificidades e necessidades, bem como ilustravam a divisão social clássica na sociedade imperial brasileira entre os interesses das classes ligadas ao setor agrícola exportador e os interesses das classes ligadas aos negócios internos.

Apesar de tal debate ser muito útil para se analisar a forma como o pensamento econômico se difundia nas instâncias que formulavam e decidiam a política econômica, percebemos que, como toda generalização, trata-se de uma classificação a posteriori e que, por isso, em diversos momentos, insuficiente para entender e explicar determinado personagem. Diante disso, como forma de ilustrar melhor o próprio debate, apresentamos as ideias de Rodrigues Torres, Sousa Franco e Mauá. Tal discussão nos mostrou que eles baseavam suas ideias tanto em crenças individuais quanto em interesses específicos referentes à posição social que ocupavam, bem como se utilizavam de adaptações e críticas ao pensamento econômico produzido no exterior como forma de conceber ideias com características próprias, não só originais, mas com viés prático, de ação em relação a determinado problema ou objetivo.

Esperamos, portanto, ter caracterizado, sistematizado e organizado o que acreditamos ser não só a gênese e a formação, como o próprio Pensamento Econômico Brasileiro no século XIX. 


\section{Referências Bibliográficas}

AGUIAR, Pinto de. A Abertura dos Portos - Cairu e os Ingleses. Salvador: Progresso Editora, 1960.

ALMEIDA, José de. Atualidade das Idéias Econômicas do Visconde de Cairu In, SILVA LISBOA, José da. Estudos do Bem Comum e Economia Política. Rio de Janeiro: IPEA/INPES, 1975.

ALMODOVAR, António e CARDOSO, José Luís. A History of Portuguese Economic Thought. Londres: Routledge, 1998.

AMZALAK, Moses B. Do estudo e da evolução das doutrinas econômicas em Portugal. Lisboa, 1928.

AMZALAK, Moses B. José da Silva Lisboa, o visconde de Cairu (17561835). Revista Brasília, Coimbra, 1943.

ANDERSON, Perry. Linhagens do Estado absolutista. São Paulo: Brasiliense, 1989.

ANDRADE, Ana Maria Ribeiro de. 1864: a controvérsia entre metalistas e pluralistas. Mestrado em História - Rio de Janeiro, UFRJ, 1987

ARANTES, Paulo. Providências de um crítico literário na periferia do capitalismo. In: ARANTES, Paulo; ARANTES, Otília. Sentido da formação. São Paulo: Paz e Terra, 1997.

ARIDA, Pérsio. A História do Pensamento Econômico como teoria e retórica, In: RÊGO, J.M.; GALA, P. (orgs.). A História do Pensamento Econômico como teoria e retórica: ensaios sobre metodologia em Economia. São Paulo: Ed. 34, 2003.

ARRIGHI, Giovanni. O longo século XX - Dinheiro, poder e origens de nosso tempo. Rio de Janeiro: Contraponto, 1996. 
ARRUDA, José Jobson de Andrade. Cairu: texto e contexto. In:

Historiografia: teoria e prática. São Paulo: Alameda, 2014.

ARRUDA, José Jobson de Andrade. Historiografia: Consciência Crítica da Produção Histórica. In: Historiografia: teoria e prática. São Paulo:

Alameda, 2014.

ARRUDA, José Jobson de Andrade. Historiografia: teoria e prática. São Paulo: Alameda, 2014.

ARRUDA, José Jobson de Andrade. Por uma História Econômica Renovada. Tempo. 38, 2015. No prelo.

ARRUDA, José Jobson de Andrade. Territórios Historiográficos Contemporâneos: por uma nova síntese histórica. In: Historiografia: teoria e prática. São Paulo: Alameda, 2014.

ARRUDA, José Jobson de Andrade; NOVAIS, Fernando. Prometeus e Atlantes na forja da Nação. Economia e Sociedade, Campinas, v. 12, n. 2 (21), 2003.

ARRUDA, José Jobson. O sentido da Colônia: revisitando a crise do antigo sistema colonial no Brasil (1780-1830). In: TENGARRINHA, José (Org.). História de Portugal. Bauru: Edusc, 2000.

ARRUDA, José Jobson. Uma colônia entre dois impérios: a abertura dos portos brasileiros 1800-1808. Bauru: Ed. Edusc, 2008.

ASCIUTTI, Monica Maria Rinaldi. Um Lugar para o periódico O Novo Mundo (Nova Iorque, 1870-1879). Dissertação de Mestrado. Literatura Brasileira. FFLCH-USP, 2010.

BARBOZA FILHO, Rubem. Tradição e artifício: iberismo e barroco na formação americana. Belo Horizonte: Ed UFMG; Rio de Janeiro: IUPERJ, 2000. 
BASTOS, Humberto. O Pensamento Industrial no Brasil. São Paulo: Livraria Martins Editora, 1952.

BEAUCLAIR, Geraldo. Introdução ao Estudo do Pensamento Econômico. Rio de Janeiro: Ed. Americana, 1974.

BEAUCLAIR, Geraldo. M. O. A construção inacabada: a economia brasileira (1820-1860). Rio de Janeiro: Vício de leitura, 2001.

BENTIVOGLIO, Julio Cesar. O Império das circunstâncias - O Código Comercial e a política econômica brasileira (1840-1860). Tese de Doutorado História Econômica. FFLCH-USP, 2002.

BERGAMINI, Atilio. "Instinto de nacionalidade" na imprensa liberal. Machado Assis em Linha, vol.6 no.12 Rio de Janeiro Dec. 2013.

BESOUCHET, Lídia. Mauá e seu tempo. Rio de Janeiro: Ed. Nova Fronteira, 1978.

BIANCHI, Ana Maria. A pré-história da Economia. São Paulo: Hucitec, 1988.

BIELSCHOWSKY, Ricardo. Eugênio Gudin. In: SZMRECSÁNYI, Tamás.; COELHO, Francisco da Silva (Orgs.). Ensaios de História do Pensamento Econômico no Brasil Contemporâneo. São Paulo: Atlas, 2007.

BIELSCHOWSKY, Ricardo. Pensamento Econômico Brasileiro: o ciclo ideológico do desenvolvimentismo. Rio de Janeiro: Contraponto, 2004.

BLAUG, Mark. Economic theory in retrospect. 3. ed. Cambridge; London: Cambridge University, 1983.

BLAUG, Mark. No History of Ideas, Please, We're Economists. The Journal of Economic Perspectives, Vol. 15, No. 1, 2001.

BLAUG, Mark. On the Historiography of Economics. Journal of the History of Economic Thought, 12, 1990. 
BRAUDEL, Fernand. O Mediterrâneo e o Mundo Mediterrânico no Época de Filipe II. São Paulo: Martins Fontes, 1983. 3 Vol.

BRESSER-PEREIRA, L. C. Interpretações sobre o Brasil. In: LOUREIRO, Maria Rita (org.). 50 anos de Ciência Econômica no Brasil (1946-1996): pensamento, instituições, depoimentos. Petrópolis, RJ: Vozes, 1997. BUENO, Luiz de Freitas. A evolução do ensino de economia no Brasil. Ensaios econômicos da EPGE, n.5. Rio de Janeiro: IBRE/FGV, 1972. BULHÕES, Octávio Gouvêa.; PELÁEZ, Carlos Manuel. Introdução a Propósito da Intermediação Financeira. In: SOUZA FRANCO, Bernardo. Os Bancos do Brasil. Brasília, Ed. UnB, 1983.

CALDEIRA, Jorge. Mauá: empresário do império. Rio de Janeiro: Companhia das Letras, 1995.

CANDIDO, Antonio. Literatura e Sociedade. São Paulo: Publifolha, 2000 CANDIDO, Antonio. O Significado de Raízes do Brasil. In: HOLANDA, Sérgio Buarque de. Raízes do Brasil. São Paulo: Cia das Letras, 1995.

CANTARINO, Nelson Mendes. A razão e ordem: o Bispo José Joaquim da Cunha de Azeredo Coutinho e a defesa ilustrada do Antigo Regime português (1742-1821). Tese de Doutorado. Universidade de São Paulo, 2012.

CANTARINO, Nelson Mendes. Conjugando tradições: o pensamento econômico do bispo Azeredo Coutinho entre a herança ibérica e as ideias ilustradas setecentistas (1791-1816). Revista História Econômica \& História de Empresas, v.15, n.2, 2012.

CARDOSO, José Luís. 1808: o ano zero da autonomia econômica do Brasil In: COUTO, Jorge (dir.). RIO DE JANEIRO CAPITAL DO IMPÉRIO PORTUGUÊS (1808-1821). Fundação Calouste Goubenkian, 2010. 
CARDOSO, José Luis. História do Pensamento Econômico Português.

Temas e problemas. Lisboa: Livros Horizonte, 2001.

CARDOSO, José Luís. O liberalismo econômico na obra de José da Silva Lisboa. História Econômica e Economia de Empresas, V.1, 2002.

CARDOSO, José Luís. O pensamento econômico em Portugal nos finais do século XVIII (1780-1808). Lisboa: Editorial Estampa, 1989.

CARDOSO, José Luís. O pensamento econômico em Portugal nos finais do século XVIII (1780-1808). Lisboa: Editorial Estampa, 1989.

CARDOSO, José Luis. Pensar a Economia em Portugal. Digressões históricas. São Paulo: Difel, 1997.

CARDOSO, José Luís. Reflexões periféricas sobre a difusão internacional do pensamento econômico. Nova Economia. vol.19 no.2, Belo Horizonte Mai/Set., 2009.

CARDOSO, José Luís. The International Diffusion of Economic Thought. In: SAMUELS, Warren; BIDDLE, Jeff E.; DAVIS, John B. (eds) A companion to the history of economic thought. Oxford, England: Blackwell Publishing, 2007.

CARVALHO, Darcy. Desenvolvimento e livre comércio: as ideias econômicas e sociais do Visconde de Cairu - um estudo de história do pensamento econômico brasileiro. São Paulo: IPE-USP, 1985.

CARVALHO, José Murilo de. A Construção da Ordem: a elite política imperial e Teatro das Sombras: a política imperial. 2.ed. ver. Rio de Janeiro: Editora UFRJ, Relume-Dumará, 1996.

CASTRO, Armando de. O Pensamento Económico no Portugal Moderno. Biblioteca Breve, Vol. 48, Instituto de Cultura Portuguesa, 1980.

CHANG, Há-Joo. Chutando a Escada: a estratégia do desenvolvimento em perspectiva histórica. São Paulo: Ed. Unesp, 2004. 
CORREA, Maria Letícia. Engenharia, economia política e progresso: a trajetória do engenheiro Luiz Rafael Vieira Souto como estudo de caso (1849-1922). Revista Brasileira de História da Ciência, Rio de Janeiro, v. 3, n. 2, p. 157-169, jul-dez 2010.

COSENTINO, Daniel. Um múltiplo de transições: a transição do trabalho escravo para o trabalho livre em Minas Gerais. Dissertação (Mestrado), UNICAMP, 2006.

COSENTINO, Daniel; GAMBI, Thiago e SILVA, Roberto. Adaptação e originalidade na construção de um pensamento econômico nacional. In: XVIII Encontro Nacional de Economia Política, 2013, Belo Horizonte. Anais XVIII Encontro Nacional de Economia Política, 2013.

COSTA, Emilia Viotti da. Da Monarquia a República. São Paulo: Unesp, 1998.

COSTA, Emilia Viotti. A Abolição. São Paulo: Global Ed., 1982.

COSTA, Wilma Peres. A Espada de Dâmocles, o Exército, a Guerra do Paraguai e a crise do Império. SP/Campinas: Ed. Unicamp, Hucitec, 1996.

COSTA, Wilma Peres. O processo de construção do Estado no Brasil (1808-1850). In: SZMRECSÁNYI, T.; LAPA, J.R.A. (orgs.). História Econômica da Independência $e$ do Império. São Paulo: Hucitec/ABPHE/Edusp/Imprensa Oficial, 2002.

COUTINHO, José J. C. Azeredo. Obras econômicas. São Paulo: Companhia Editora Nacional, 1966.

DIAS, Maria Odila da Silva. A interiorização da metrópole (1808-1853). In: MOTA, Carlos Guilherme. 1822: Dimensões. São Paulo: Editora Perspectiva, 1972.

DOBB, Maurice. Teorias do Valor e Distribuição desde Adam Smith. Lisboa: Presença, 1976. 
DOSSE, François. A História em Migalhas. Bauru: EDUSC, 2003.

FAORO, Raymundo. Existe um pensamento político brasileiro? Estudos Avançados, vol.1 no.1 São Paulo Oct./Dec. 1987.

FAORO, Raymundo. Os Donos do Poder: formação do patronato político brasileiro. São Paulo: Publifolha, 2000.

FARIA JUNIOR, Carlos. O pensamento econômico de José da Silva Lisboa, Visconde de Cairu. 2 vol., Tese de Doutorado em História Econômica FFLCH-USP, São Paulo, 2008.

FERNANDES, Santiago. Mauá, o economista do império. Análise de sua crítica científica ao padrão-ouro. Revista Brasileira de Economia, Rio de Janeiro, 28 (2):3-28, abr./jun., 1974.

FONSECA, Pedro Cezar Dutra. A controvérsia entre papelismo e metalismo e a gênese do desenvolvimentismo no Brasil. In: Anais do XXXVI Encontro Nacional de Economia da ANPEC, Salvador, 2008.

FONSECA, Pedro Cezar Dutra.; MOLLO, Maria de Lourdes Rollemberg. Metalistas x papelistas: origens teóricas e antecedentes do debate entre monetaristas e desenvolvimentistas. Nova Economia, Belo Horizonte, 22(2), p.203-233, maio-agosto, 2012.

FONTANA, J. A História do homens. Bauru: Edusc, 2004.

FONTANA, J. História - análise do passado e projeto social. Bauru: Edusc, 2004.

FRANCO, Maria Sylvia de Carvalho. As ideias estão em seu lugar. Cadernos de Debate, 1976.

FREYRE, Gilberto. Casa-grande \& senzala: formação da família brasileira sob o regime da economia patriarcal. 51 a Ed. Ver., São Paulo: Global, 2006. 
FURTADO, Celso. Formação Econômica do Brasil. São Paulo: Companhia das Letras, 2009.

GAMBI, Thiago, O banco da Ordem: política e finanças no Império brasileiro (1853-1866). 1. ed. São Paulo: Alameda/Fapesp, 2015.

GAMBI, Thiago. O debate político e o pensamento econômico no Império brasileiro: centralização de poder e monopólio de emissão no segundo Banco do Brasil (1852-1853). In: Almanack. Guarulhos, n.09, p.176-189, abril, 2015.

GAMBI, Thiago. Pensamento econômico na periferia: um esboço das ideias econômicas de Joaquim José Rodrigues Torres (1848-1858). In: IV ESHET - Latin American Conference, Cedeplar-UFMG, Belo Horizonte, 2014.

GANEM, Ângela. A História do Pensamento Econômico Brasileiro como questão. In: MALTA, Maria Mello de. (org.) Ecos do desenvolvimento. Rio de Janeiro: IPEA, Centro Celso Furtado, 2011.

GANEM, Ângela. Reflexões sobre a História do Pensamento Econômico Brasileiro. Análise Econômica, v.59, n.26, 2011.

GORENDER, Jacob. A Escravidão Reabilitada. São Paulo: Ática, 1991

GREMAUD, Amaury. P. Das controvérsias teóricas à política econômica. Tese de doutorado. Universidade de São Paulo. 1997.

GUIMARÃES, Carlos Gabriel. A PRESENÇA INGLESA NAS FINANÇAS E NO COMÉRCIO NO BRASIL IMPERIAL: os casos da sociedade bancária Mauá, MacGregor \& Cia. (1854-1866) e da firma inglesa Samuel Phillips \& Cia. (1808-1840). São Paulo: Alameda, 2012.

HESPANHA, A.M. As vésperas do Leviathan: instituições e poder político. Portugal - século XVII. Coimbra: Livraria Almedina, 1994.

HOBSBAWN, E. Sobre história. São Paulo: Cia das Letras, 1998. 
HOLANDA, Sérgio Buarque de. A Herança colonial - sua desagregação. In: História Geral da Civilização Brasileira - O Brasil Monárquico: o Processo de Emancipação. Tomo II, $1^{\circ}$ Volume, São Paulo - Rio de Janeiro: DIFEL, 1976.

HOLANDA, Sérgio Buarque de. Raízes do Brasil. São Paulo: Cia das Letras, 1995.

HOLANDA, Sérgio Buarque. Inatualidade de Cairu. In: Por uma nova história. São Paulo: Ed. Fundação Perseu Abramo, 2004.

HUGON, Paul. A Economia Política no Brasil. In: AZEVEDO, Fernando de (org.). As Ciências no Brasil. 2a Ed., V.2., Rio de Janeiro: Editora UFRJ, 1994.

IGLÉSIAS, Francisco. Introdução à historiografia econômica. Belo Horizonte: FCE/UFMG, 1959.

JURUÁ, Ceci. Irineu Evangelista de Souza, Barão e Visconde de Mauá: defensor do nacionalismo econômico do Oiapoque ao Chuí. Rio de Janeiro: Jardim Objeto, 2013.

KIRSCHNER, Tereza Cristina. José da Silva Lisboa, Visconde de Cairu: itinerários de um ilustrado Iuso-brasileiro. São Paulo: Alameda; Belo Horizonte: Ed. PUC-Minas, 2009.

LEVY, Maria Bárbara. O Encilhamento. In: NEUHAUS, Paulo (coord.). Economia brasileira. Uma visão histórica. Rio de janeiro: Ed. Cmapus, 1980.

LIMA, Alceu Amoroso. Época, vida e obra de Cairu. In: SILVA LISBOA, José da. Princípios de Economia Política. Rio de Janeiro: Ed. Irmãos Pongetti, 1956.

LIMA, Heitor Ferreira. História do Pensamento Econômico no Brasil. São Paulo: Cia Ed. Nacional, 1976. 
LIMA, Heitor, Ferreira. 3 Industrialistas brasileiros: Mauá, Rui Barbosa, Roberto Simonsen. São Paulo: Alfa-Omega, 1976b.

LIST, Georg Friedrich. Sistema nacional de economia política. São Paulo: Abril Cultural, 1983.

LOUREIRO, Maria Rita (org.). 50 anos de Ciência Econômica no Brasil (1946-1996): pensamento, instituições, depoimentos. Petrópolis, RJ: Vozes, 1997.

LUZ, Nícia Vilela. A luta pela industrialização do Brasil. São Paulo: Ed. Alfa Omega, 1978.

MACHADO DE ASSIS. Instinto de Nacionalidade. O Novo Mundo, 24/03/1873. (Posteriormente em Obra Completa de Machado de Assis, Rio de Janeiro: Nova Aguilar, vol. III, 1994.)

MAGALHÃES, Pablo A. Iglesias. Flores Celestes: O livro secreto de José da Silva Lisboa, o visconde de Cairú?. História (São Paulo), v.31, n.1, p. 65100 , jan/jun 2012.

MALTA, Maria Mello de (org.). Ecos do Desenvolvimento. Rio de Janeiro: IPEA, Centro Celso Furtado, 2011.

MALTA, Maria; CURTY, Carla; BORJA, Bruno. Intérpretes do Brasil: influências na origem do pensamento econômico brasileiro. In: Anais XVI Seminário sobre a economia mineira, CEDEPLAR-UFMG, Diamantina, 2014.

MANTEGA, Guido. A economia política brasileira. São Paulo/Petrópolis: Vozes, 1985.

MARX, Karl. Para Crítica da Economia Política. São Paulo: Abril Cultural, 1974.

MATTOS, Ilmar Rohloff de. O tempo saquarema. A formação do Estado imperial. Rio de Janeiro: ACCESS, 1994. 
MAUÁ, Irineu Evangelista de Sousa. O meio circulante do Brasil. In: LIMA, Heitor, Ferreira. 3 Industrialistas brasileiros: Mauá, Rui Barbosa, Roberto Simonsen. São Paulo: Alfa-Omega, 1976b.

MOLLO, Maria de Lourdes Rollemberg. As controvérsias monetárias do século XiX. Ensaios FEE, Porto Alegre, 15-1, 1994.

MORSE, Richard. A Miopia de Schwartzman. Novos Estudos CEBRAP, 24, julho, 1989.

MORSE, Richard. O espelho de Próspero: cultura e ideias nas Américas. São Paulo: Companhia da Letras, 1988.

NOGUEIRA DE PAULA, Luiz. Introdução. In: SILVA LISBOA, José da. Princípios de Economia Política. Rio de Janeiro: Ed. Irmãos Pongetti, 1956. NOGUEIRA DE PAULA, Luiz. Síntese da Evolução do Pensamento Econômico no Brasil. Rio de Janeiro: Serviço de Estatística da Previdência e Trabalhos, 1942.

NOVAIS, Fernando A. As Dimensões da Independência. In: MOTA, Carlos Guilherme. 1822: Dimensões. São Paulo: Editora Perspectiva, 1972.

NOVAIS, Fernando A. Caio Prado Jr. na historiografia brasileira. In: MORAES, R. et al. (orgs.). Inteligência brasileira. São Paulo: Ed. Brasiliense, 1986.

NOVAIS, Fernando A. Portugal e Brasil na crise do antigo sistema colonial. São Paulo: Hucitec, 1979.

NOVAIS, Fernando A.; ARRUDA, Maria Arminda do Nascimento. Apresentação: revisitando os intérpretes do Brasil. Revista USP, (38): 6-9, Junho/Agosto, 1998.

NOVAIS, Fernando.; MOTA, Carlos Guilherme. A Independência política do Brasil. São Paulo: Hucitec, 1996. 
OLIVEIRA, Lúcia Lippi. Americanos: representação da identidade nacional no Brasil e nos EUA. Belo Horizonte: Ed. UFMG, 2000.

PAIM, Antonio. Cairu e o Liberalismo Econômico. Assembleia Legislativa do Estado da Bahia, 2008. (1a. edição - pela Editora Tempo Brasileiro, 1968)

PAULA, João Antonio; CERQUEIRA, Hugo. Sobre Isaac Rubin e sua História do Pensamento Econômico. Apresentação In: Rubin, Isaac. História do Pensamento Econômico. Rio de Janeiro: Ed. UFRJ, 2014.

PAULA, João Antonio; CERQUEIRA, Hugo; ALBUQUERQUE, Eduardo. Nações e estilos de Economia Política. Revista de Economia Política, vol. 27, no 3 (107), pp. 357-374, julho-setembro/2007.

PELAEZ, Calos Manuel. As Consequências Econômicas da Ortodoxia Monetária, Cambial e Fiscal no Brasil entre 1889-1945. Revista Brasileira de Economia, Rio de Janeiro, 25 (3):5/82, jul./set. 1971.

PELAEZ, Carlos Manuel; SUZIGAN, Wilson. História Monetária do Brasil. Brasília: Editora Universidade de Brasília, 1981.

PEREIRA, José Flávio. Cairu revisitado: uma contribuição ao estudo do reformismo liberal. Tese de Doutorado. História Social, FFLCH-USP, São Paulo, 1994.

PINHO, Diva Benevides. Economia política e a História das doutrinas econômicas. Estudos Avançados. vol.8 no.22 São Paulo Sept./Dec. 1994. PRADO JUNIOR, Caio. Formação do Brasil Contemporâneo: colônia. São Paulo: Cia das Letras, 2011.

RICUPERO, Bernardo. Sete lições sobre as interpretações do Brasil. São Paulo: Alameda, 2008.

ROCHA, Antonio Penalves. A economia política na sociedade escravista. São Paulo: Hucitec, 1996. 
ROCHA, Antônio Penalves. A Economia Política no mundo português do início do século XIX. In: A recolonização do Brasil pelas cortes: histórias de uma invenção historiográfica. São Paulo: Ed. UNESP, 2009.

ROCHA, Antônio Penalves. Economia e política no período joanino. In: LAPA, José Roberto do Amaral e SZMRECSÁNYI, Támas. História econômica da Independência e do Império. São Paulo: Edusp, Hucitec, ABPHE, 1996.

ROCHA, Antônio Penalves. Introdução. In: José da Silva Lisboa, visconde de Cairu. São Paulo: Ed. 34, 2001

RODRIGUES, José Honório. História da História do Brasil. v. II, t. I. São Paulo: Companhia Editora Nacional, 1988.

SAES, Flávio. Crédito e Bancos no desenvolvimento da Economia Paulista. 1850-1930). São Paulo: IPE-USP, 1986.

SAES, Flávio. Mauá e sua presença na economia brasileira do século XIX. In: Barão de Mauá. Empresário e Político. Rio de Janeiro: Bianchi Ed., 1987.

SÁEZ, Hernán Enrique Lara. Nas asas de Dédalo : um estudo sobre o meio circulante no Brasil entre os anos de 1840 a 1853. São Paulo:Humanitas, 2010.

SÁEZ, Hernán Enrique Lara. O TONEL DAS DANAIDES: um estudo sobre o debate do meio circulante no Brasil entre os anos de 1850 a 1866 nas principais instâncias decisórias. Tese de Doutorado , História Econômica, FFLCH-USP, 2013.

SANTOS, Wanderley Guilherme dos. Ordem burguesa e liberalismo político. São Paulo: Livraria Duas Cidades, 1978.

SCHUMPETER, Joseph. História da Análise Econômica. $1^{\circ}$ Volume, Rio de Janeiro: Fundo de Cultura, 1964. 
SCHUMPETER, Joseph. História da Análise Econômica. $3^{\circ}$ Volume, Rio de Janeiro: Fundo de Cultura, 1964b.

SCHWARTZ, Stuart S. Escravos, roceiros e rebeldes. Bauru, SP: EDUSC, 2001.

SCHWARTZMAN, Simon. As bases autoritárias do Estado brasileiro. Rio de Janeiro: Campus, 1988.

SCHWARTZMAN, Simon. O Espelho de Morse. Novos Estudos CEBRAP, 22, Outubro, 1988.

SCHWARTZMAN, Simon. O gato de Cortázar. Novos Estudos CEBRAP, 25, outubro, 1989.

SCHWARZ, Roberto. Ao vencedor as batatas. São Paulo: Ed. 34, 2000.

SILVA LISBOA, Bento da. José da Silva Lisboa, Visconde de Cairú. Revista do Instituto Histórico e Geográfico Brasileiro, Rio de Janeiro, v. 1, 1839.

SILVA LISBOA, José da. Estudos do Bem Comum e Economia Política. Rio de Janeiro: IPEA/INPES, 1975.

SILVA LISBOA, José da. José da Silva Lisboa, visconde de Cairu. São Paulo: Ed. 34, 2001.

SILVA LISBOA, José da. Observações sobre a franqueza da indústria e estabelecimento de fábricas no Brasil. Brasília: Senado Federal, 1999.

SILVA LISBOA, José da. Observações sobre o commercio franco no Brasil In: José da Silva Lisboa, visconde de Cairu. São Paulo: Ed. 34, 2001.

SILVA LISBOA, José da. Princípios de Economia Política. Rio de Janeiro: Ed. Irmãos Pongetti, 1956.

SILVA, Jair Ribeiro da. Mauá em face da economia nacional. São Paulo: Rumo Gráfica Ed., 1983. 
SILVA, Roberto Pereira. Celso Furtado, Entre a História e a Teoria Econômica (1948-1959): uma interpretação historiográfica. Tese de Doutorado em História Econômica. FFLCH-USP, São Paulo, 2015.

SILVA, Roberto Pereira. O Jovem Celso Furtado; história, política e economia (1941-1948). Bauru: EDUSC, 2011.

SOUZA FRANCO, Bernardo. Os Bancos do Brasil. Brasília, Ed. UnB, 1983.

SOUZA, Ricardo Timm de.; FOSSATTI. Nelson Costa. (orgs.). Mauá:

paradoxos de um visionário. Porto Alegre: Letra\&Vida, 2013.

SZMRECSÁNYI, Tamás; COELHO, Francisco da Silva (Orgs.). Ensaios de História do Pensamento Econômico no Brasil Contemporâneo. São Paulo: Atlas, 2007.

TEIXEIRA, Arilda C. Determinantes e armadilhas da política monetária brasileira no II Império. Dissertação de Mestrado, Niterói, UFF, 1991.

URICOECHEA, Fernando. O minotauro imperial: a burocratização do Estado patrimonial brasileiro no século XIX. Rio de Janeiro: Difel, 1978. VIEIRA, Dorival Teixeira. A História da Ciência Econômica no Brasi. In: FERRI, Mário Guimarães; MOTOYAMA, Shozo. (org.). História das Ciências no Brasil. São Paulo: EPU: Edusp, 1979-1981.

VIEIRA, Dorival Teixeira. Evolução do sistema monetário brasileiro. São Paulo: IPE/USP, 1981

VILLELA, André. The political economy of money and banking in Imperial Brazil 1850-1870. Doutorado em História Econômica - London School of Economics and Political Science, 1999.

VILLELA, André. The Quest for Gold: Monetary Debates in Nineteenthcentury Brazil. Brazilian Journal of Political Economy, vol. 21, no 4 (84), October-December, 2001. 
WERNECK VIANNA, Luiz. A revolução passiva: iberismo e americanismo no Brasil. Rio de Janeiro: Revan, 1997. 